\title{
MANEJO DE SOLO SALINO-SÓDICO \\ NA REGIÃO DO BAIXO AÇU-RN
}

\section{JOSÉ SIMPLÍCIO DE HOLANDA}

Engenheiro Agrônomo

Orientador: Prof. Dr. GODOFREDO CESAR VITTI

\begin{abstract}
Tese apresentada à Escola Superior de Agricultura "Luiz de Queiroz", Universidade de São Paulo, para obtenção do título de Doutor em Agronomia, Área de Concentração: Solos e Nutrição de Plantas
\end{abstract}

PIRACICABA

Estado de São Paulo - Brasil

Junho - 1996 
Dados Internacionais de Catalogação na Publicação (CIP)

DIVISĀO DE BIBLIOTECA E DOCUMENTAÇĀO - Campus "Luiz de Queiroz"/USP

Holanda, José Simplício de

Manejo de solo salino-sódico na Região do Baixo Açú-RN / José

Simplicio de Holanda. - - Piracicaba, 1996.

84p. : il.

Tese (doutorado) - - Escola Superior de Agricultura Luiz de Queiroz, 1996.

Bibliografia.

1. Solo salino-sódico - Manejo - Rio Grande do Norte I. Título

CDD $\quad 631.416$ 


\title{
MANEJO DE SOLO SALINO-SÓDICO NA REGIÃO DO BAIXO AÇU-RN
}

\author{
JOSÉ SIMPLÍCIO DE HOLANDA
}

Aprovada em: $\quad 04.06 .96$

Comissão julgadora:

Prof. Dr. GODOFREDO CESAR VITTI

ESALQ/USP

Prof. Dr. TAKASHI MURAOKA

CENA/USP

Prof. Dr. TOSHIAKI KINJO

ESALQ/USP

Prof. Dr. HANS RAJ GHEYI

$\mathrm{CCT} / \mathrm{UFPB}$

Prof. Dr. MAURÍCIO DE OLIVEIRA

ESAM

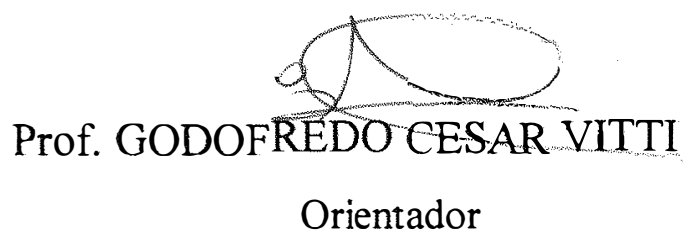




\section{MENSAGEM DE AGRADECIMENTO}

Foram tantos os que contribuiram para que este trabalho fosse perfeito que, com receio de não ser justo, pecando por omissão, preferi não nominá-los.

Entretanto, a você que de alguma forma trabalhou para a realização desta pesquisa bem o sabes o quanto agradeço. $\mathrm{O}$ nosso esforço não foi em vão pois a ciência foi enaltecida. Que Deus multiplique por números inteiros a disposição de trabalhar e que sempre nos lembremos da mensagem de São Paulo apóstolo quando diz:

- Eviteis a convivência com quem leva vida ociosa;

- Obterás o pão que alimenta com trabalho e fadiga.

- AQUELE QUE NÃO QUER TRABALHAR NÃO TEM O DIREITO DE COMER! 


\section{SUMÁRIO}

Página

LISTA DE FIGURAS.................................................................... vi

LISTA DE TABELAS............................................................................. viii

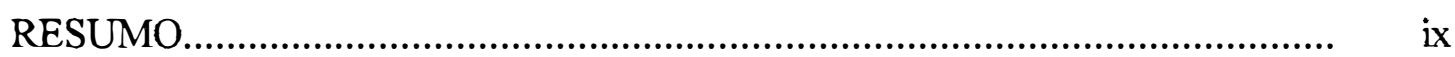

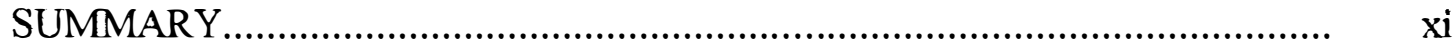

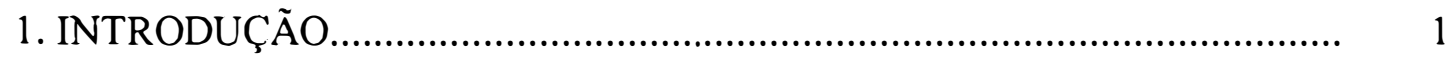

2. REVISÃO DE LITERATURA............................................................. 4

2.1. Solos afetados por sais: origem, caracterização e dimensão do problema.... 4

2.2. Uso de gesso para melhorias de solos salino-sódicos.................................... 9

2.3. O preparo do solo em áreas afetadas por sais............................................ 15

2.4. Uso de resíduos orgânicos e cultivo de plantas tolerantes em solos

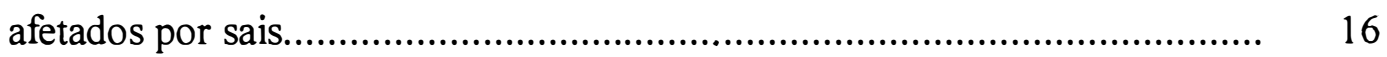

2.5. Influência de técnicas de correção na produção vegetal................................. 19

3.MATERIAL E MÉTODOS.................................................................... 22

3.1. Descrição e caracterização da área geográfica.............................................. 22

3.2. Aspectos climáticos da Região do Baixo Açu.............................................. 23

3.3. A formação aluvional da Região do Baixo Açu........................................... 23

3.4. Histórico da área experimental................................................................ 25

3.5. Ensaio de doses de gesso ..................................................................... 27

3.6. Ensaio comparativo de métodos de correção do solo................................... 31

4. RESULTADOS E DISCUSSÃO................................................................. 35

4.1. Salinidade do solo................................................................................ 35

4.1.1. Efeito dos condicionadores.................................................................... 35

4.1.2. Efeito do preparo do solo.................................................................... 39

4.2. Porcentagem de sódio trocável (PST),........................................................ 41

4.2.1. Efeito dos condicionadores.................................................................... 41

4.2.2. Preparo do solo................................................................................... 47

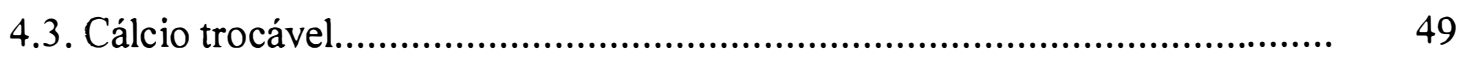


Página

4.4. Bases trocáveis e alcalinidade................................................................... 53

4.5. Balanço iônico .................................................................................... 56

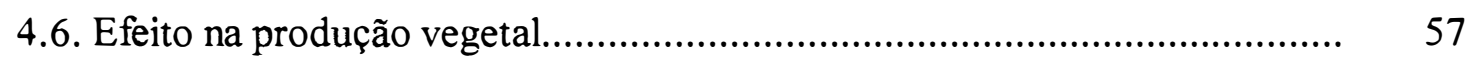

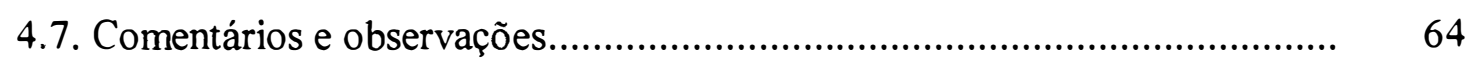

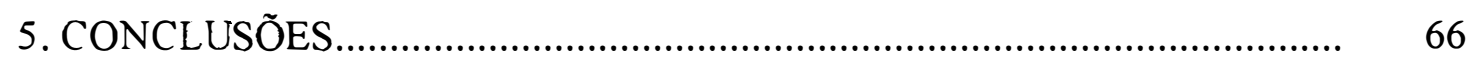

REFERÊNCIAS BIBLIOGRÁFICAS............................................................ 68

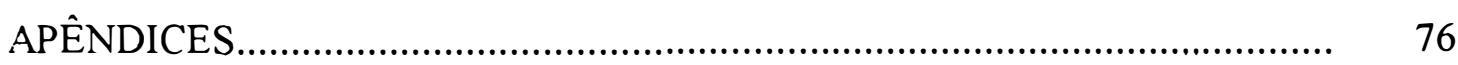

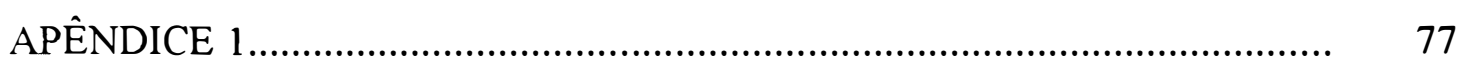

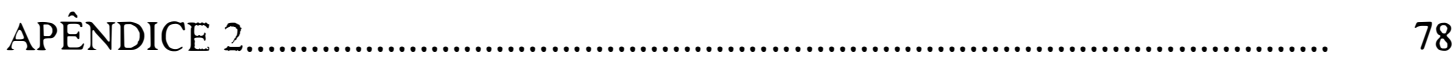

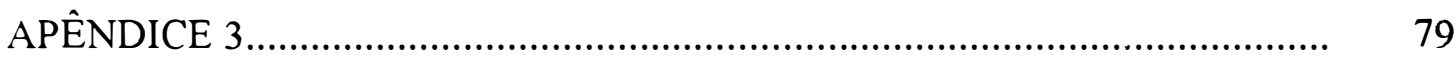

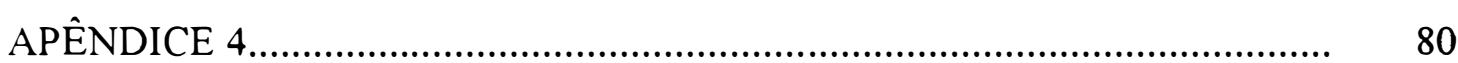

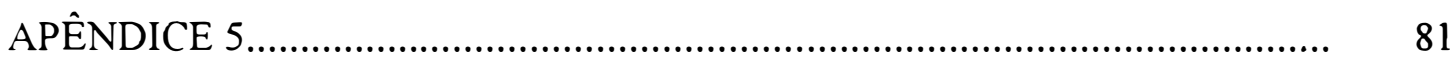

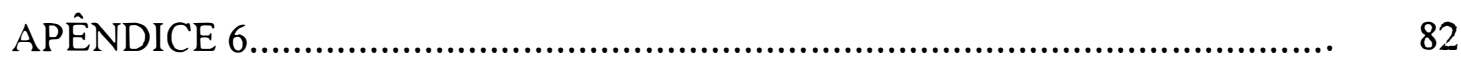

APÊNDICE 7 …………………………………………………….....

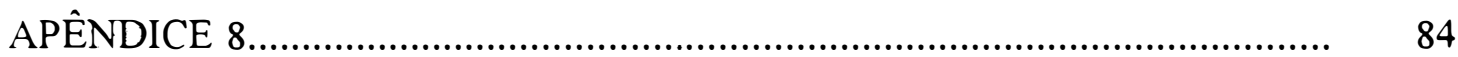




\section{LISTA DE FIGURAS}

Página

1 Velocidade de infiltração de água no solo aluvial salino-sódico de Ipanguassu-RN.

2 Condutividade elétrica em extratos saturados (C. Ees) de profundidades do solo, em duas épocas após a aplicação de $0,10,20$ e $30 \mathrm{Mg} \cdot \mathrm{ha}^{-1}$ de gesso: 30 meses (a) e 60 meses (b)

3 Condutividade elétrica em extratos saturados (C. Ees) de profundidades do solo, em três épocas após a aplicação dos condicionadores e sob duas condições de preparo do solo: Sem subsolagem. após nove meses (a), após 24 meses(c) e após 40 meses (d); com subsolagem, após 9 meses (b) e após 40 meses (e).

4 Porcentagem de sódio trocável (PST) em profundidades do solo, em 4

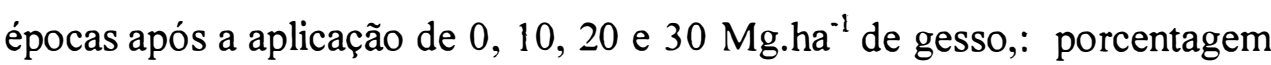
de sódio extraível (PSE) aos 6 meses (a), PST aos 12 meses (b), PST aos 30 meses (c) e PST aos 60 meses (d).

5 Porcentagem de sódio trocável (PST) em profundidades do solo, em três épocas após a aplicação dos condicionadores e sob duas condições de preparo do solo: Sem subsolagem após nove meses (a), após 24 meses (c ) e após 40 meses (e); com subsolagem após 9 meses (b), após 24 meses (d) e após 40 meses $(\mathrm{f})$

6 Cálcio trocável em profundidades do solo, em 4 épocas após a aplicação de $0,10,20$ e 30 Mg.ha ${ }^{-1}$ de gesso,: cálcio extraível após 6 meses (a), cálcio trocável após 12 meses (b), cálcio trocável após 30 meses; e cálcio trocável após 60 meses $(\mathrm{d})$.

7 Cálcio trocável em profundidades do solo, em três épocas após a aplicação dos condicionadores: após nove meses (a), após 24 meses (b) e após 40 meses (c) 
Página

8 Efeito de doses de gesso na produção de culturas, em duas épocas após aplicação: após três meses, algodão CNPA-precoce1 irrigado por aspersão (a) e após 54 meses, arroz metica-1 irrigado por inundação (b)................... 


\section{LISTA DE TABELAS}

Página

1 Situação mundial de solos afetados por sais............................................... 5

2 Áreas de solos afetados por sais em sete Estados do Nordeste do Brasil.... 6

3 Valores limites de C.E Es e PST para salinidade e sodicidade de solos............ 6

4 Caracterização física, teor inicial de cátions solúveis e níveis de salinidade no perfil do solo aluvial salino-sódico de Ipanguassu, RN.......................... 26

5 Capacidade de troca de cátions, porcentagem de sódio trocável (PST) e parâmetros iniciais de fertilidade do solo aluvial salino-sódico de Ipanguassu, RN. Médias de 16 determinações............................................. 26

6 Composição quimica dos condicionadores orgânicos.................................... 32

$7 \quad$ Cronograma de execução dos ensaios em campo........................................... 34

8 Composição de cátions trocáveis no complexo sortivo do solo, em área sem subsolagem, 24 meses após a aplicação dos condicionadores, ensaio de métodos de correção de solo salino-sódico, médias de 4 repetições........

9 Composição de cátions trocáveis no complexo sortivo do solo, em área subsolada, 24 meses após a aplicação dos condicionadores, ensaio de métodos de correção de solo salino-sódico, médias de 4 repetições.............

10 Balanço iônico na solução do solo (extrato saturado) em área sem subsolagem, 40 meses após a aplicação dos condicionadores, ensaio de métodos de recuperação de solo salino-sódico, médias de 4 repetições.......

11 Balanço iônico na solução do solo (extrato saturado) em área subsolada, 40 meses após a aplicação dos condicionadores, ensaio de métodos de correção de solo salino-sódico, médias de 4 repetições.

12 Rendimentos de arroz e algodão em diferentes épocas após a aplicação dos condicionadores e resumo das análises estatísticas. Ensaio de métodos de correção, médias de 4 repetições em solo sem e com subsolagem........... 


\title{
MANEJO DE SOLO SALINO-SÓDICO NA REGIÃO DO BAIXO AÇU-RN
}

\author{
Autor: JOSÉ SIMPLÍCIO DE HOLANDA \\ Orientador: Prof. Dr. GODOFREDO CESAR VITTI
}

\section{RESUMO}

Solos afetados por sais se constituem em um problema mundial, de maior intensidade em zonas áridas e semi-áridas. Nas áreas aluvionais do nordeste brasileiro os solos são férteis mas, apresentam excesso de sais. Esta pesquisa objetiva avaliar o efeito de diferentes técnicas de manejo, na melhoria de um solo aluvial salino-sódico da região do Baixo Açu-RN.

Durante cinco anos foram conduzidos dois experimentos em campo, um com frações da recomendação de gesso $(0,1 / 3,2 / 3$ e $3 / 3)$ para redução da porcentagem de sódio trocável do solo (PST) a 15\%. e o segundo com condicionadores químico

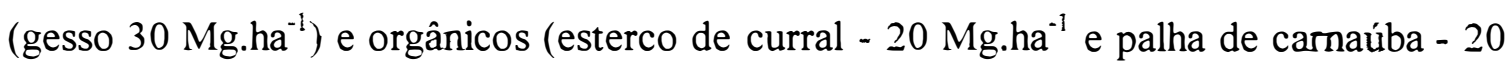
Mg.ha ${ }^{-1}$, em peso seco), sozinhos ou combinados, sob preparo de solo convencional e com acréscimo de subsolagem. Foram cultivados algodão irrigado por aspersão e arroz por aspersão ou inundação, ambas adubadas conforme recomendação de laboratório. Os parâmetros avaliados foram C. $E_{\mathrm{es}}$, PST, Cálcio trocável e pH no solo, balanço iônico na solução do solo e produção das culturas.

O gesso foi o mais eficiente condicionador na redução da PST. Seu efeito até os 9 meses ficou restrito a camada de incorporação no solo, baixando a PST para cerca de 10\%. No decorrer de 24-30 meses diminuiu a PST em profundidades de até $60 \mathrm{~cm}$ e, aos 40 meses não foi constatado efeito. $\mathrm{Na}$ fase inicial o gesso causou elevação

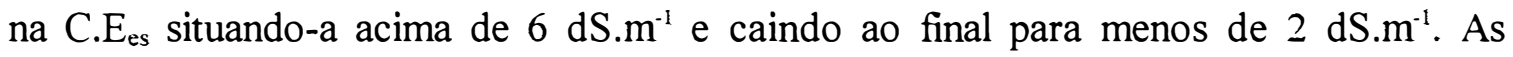


frações de $1 / 3$ e 2/3 e a recomendação integral de gesso favoreceram igualmente a

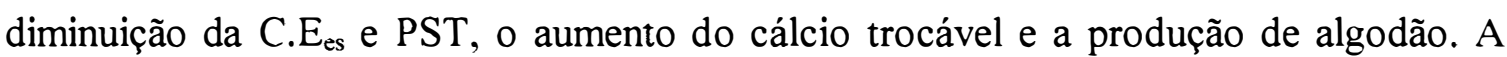
combinação do esterco de curral com gesso foi benéfica ao solo e possibilitou maior produção de algodão (cerca de $2.500 \mathrm{~kg} \cdot \mathrm{ha}^{-1}$ ) em relação a área não tratada. um ano após a aplicação.

A incorporação de palha de carnaúba sozinha agravou a condição de salinidade e sodicidade do solo e proporcionou as mais elevadas concentrações de sódio e cloro, em torno de $40 \mathrm{mmol}_{\mathrm{c}} \cdot \mathrm{L}^{-1}$, na solução do solo.

A subsolagem foi de efeito temporário na salinidade do solo porém, eficaz e prolongado na PST, com diminuição de até 14\% sobre o preparo convencional.

$\mathrm{O}$ arroz inundado mais que dobrou de produção, em relação ao irrigado por aspersão que manteve a C. $E_{\text {es }}$ acima da salinidade limiar da cultura. Os rendimentos elevados, acima de $7.600 \mathrm{~kg} \cdot \mathrm{ha}^{-1}$, foram obtidos independente da subsolagem e do uso de condicionadores.

Corrigido os desvios de fertilidade, o manejo que parece mais viável para exploração de algodão em solo aluvial salino sódico do baixo Açu compreende: 1preparo do solo com subsolagem precedendo cada cultivo ou, gessagem reduzida a 1/3 da dose recomendada, associada ou não a esterco de curral; 2- irrigação, tolerando-se por aspersão. Para arroz, é preciso tão somente irrigar por inundação, com manutenção de lâmina de água em $10 \mathrm{~cm}$ de altura. 


\title{
MANAGEMENT OF SALINE SODIC SOIL IN AÇU VALLEY OF RIO GRANDE DO NORTE, BRAZIL
}

\author{
Author: JOSÉ SIMPLÍCIO DE HOLANDA \\ Adviser: Prof. Dr. GODOFREDO CESAR VITTI
}

\section{SUMMARY}

Salt affected soil is a world problem of high intensity in arid and semi-arid region. Alluvial soils of northeast of Brazil present high fertility but excess of salt content. The objective of this research was to evaluate the different management practices for improvement of alluvial saline sodic soil of the Açu valley.

Two field experiments were conducted during five years, one with gypsum rates $(0,1 / 3,2 / 3$ and $3 / 3)$ to reduce exchangeable sodium percentage (ESP) to levels

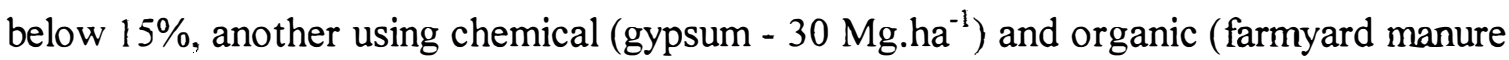
- $20 \mathrm{Mg} \cdot \mathrm{ha}^{-1}$ and camauba Copernica cerifera straw - $20 \mathrm{Mg} \mathrm{ha}^{-1}$, in dry weight basis) amendments alone or combined under conventional soil preparation with or without subsoiling. Sprinkler irrigated cotton and upland rice sprinkler or inundated were cultivated using recommended fertilization. Electrical conductivity of saturation extract $\left(\right.$ E. $\mathrm{C}_{\mathrm{se}}$ ), exchangeable sodium percentage (ESP), exchangeable calcium, soil $\mathrm{pH}$, ionic balance in soil solution and crop yields were evaluated.

Gypsum was the most efficient amendment in ESP reduction. Up to the ninth month the effects of gypsum were restricted to the soil layer in which it was applied, decreasing the ESP to levels around $10 \%$. From the 24th to 30th month gypsum decreased ESP in a deeper layer up to $60 \mathrm{~cm}$ and at the 40 th month gypsum effects on the ESP virtually ceased. Initially gypsum increased E.C $\mathrm{se}_{\mathrm{se}}$ to values higher than $6 \mathrm{dS} \cdot \mathrm{m}^{-1}$, and 
decreased those values to levels lower than $2 \mathrm{dS} . \mathrm{m}^{-1}$ at the end of experiments. Gypsum rates of $1 / 3$ and 2/3 and integral recommendation had the same effects on E. $C_{\mathrm{se}}$ and ESP decrease, exchangeable $\mathrm{Ca}$ increase and cotton yield. Farmyard manure and gypsum association had beneficial effect on general soil conditions and the cotton yield (app. $2.500 \mathrm{~kg}$. ha ${ }^{-1}$ ) was higher than the control, in the first year.

The incorporation of Copernica cerifera straw increased salinity, sodicity and sodium/chloride concentration in soil solution to levels around $40 \mathrm{mmol}_{\mathrm{c}} . \mathrm{L}^{-1}$.

Subsoiling had a temporary effect on soil salinity however this effect was efficient and persistent on soil sodicity, decreasing the ESP up to $14 \%$ in relation to the conventional soil preparation.

Inundated rice produced twofold increase in yield in relation to the sprinkler irrigated which maintained the E. $\mathrm{C}_{\text {se }}$ above threshold salinity of the crop. High yields over $7.600 \mathrm{~kg} \cdot \mathrm{ha}^{-1}$ were obtained independently of subsoiling and amendments application.

After correcting soil fertility deficiencies, the soil management that seems more viable for the cotton cropping in alluvial saline sodic soil of Açu valley involves: soil preparation preceeded by subsoiling or gypsum application equivalent to $1 / 3$ of recommendation solely or associated with farmyard manure and, sprinkler irrigated. For rice only inundation maintaining $10 \mathrm{~cm}$ water height is sufficient. 


\section{INTRODUÇÃO}

A salinidade do solo é um dos fatores mais preocupantes da agricultura moderna e a irrigação mal conduzida é um dos principais responsáveis pelo aumento da quantidade de solos degradados. Como a origem do sal pode ser marinha, lítica e antropogênica, a salinização de solos pode ocorrer em quase todas as regiões do globo (Farias, 1985).

A acumulação de sais na superficie dos solos é um problema que se conhece desde a origem da irrigação. $\mathrm{Na}$ Mesopotâmia existiam vastas áreas de terras irrigadas onde se desenvolvia na época uma agricultura avançada. Estas terras foram abandonadas por problemas de salinização. A salinização dos solos nas áreas irrigadas é um problema de preocupação mundial. A comissão Internacional de Irrigação e Drenagem, em 1970, estimou em 203 milhões de hectares a área irrigada do mundo; destes, cerca de 50,7 milhões estavam afetados por problemas de sais, que corresponde a $25 \%$ do total dos solos irrigados (Pereira, 1982).

A região Nordeste do Brasil abrange uma área de $1.600 .000 \mathrm{~km}^{2}$, dos quais, $1.500 .000 \mathrm{~km}^{2}$ (150 milhões de hectares) foram caracterizados como de insuficiência hídrica, constituindo o "polígono das secas". Nessa região a irrigação passa a assumir papel fundamental no desenvolvimento da agricultura. Gheyi \& Medeiros (1991) relatam que de acordo com estimativas do Programa Nacional de Irrigação (PRONI), no Nordeste há cerca de 6 milhões de hectares de solos potencialmente irrigáveis.

A prática da irrigação entretanto, deve ser usada de maneira racional uma vez que as condições de clima do Nordeste (altas temperaturas e baixa pluviosidade) e os elevados teores de sais nas águas de irrigação, aliados a falta ou deficiência de drenagem, tem provocado problemas de salinidade nos solos. Goes (1978) estima que $25 \%$ das 
áreas dos perímetros irrigados do DNOCS estejam salinizados e, Cordeiro et al. (1988) reforçam essa estimativa, revelando que $40 \%$ da área em operação no projeto de irrigação de São Gonçalo-PB está afetada por sais.

Entre os solos afetados por sais, os sódicos são os mais problemáticos. Os solos sódicos podem ter uma camada dura, compacta e impermeável à água a poucos centímetros de profundidade. Enquanto a acumulação de sais solúveis torna o solo floculado, fofo e bem permeável, o aumento do sódio trocável pode torná-lo adensado, compacto em condições secas, disperso e pegajoso em condições molhadas. Devido a isso, o solo sódico apresenta permeabilidade baixa, e qualquer excesso de água fica estagnada na superficie impedindo a germinação das sementes e crescimento das plantas, por falta de aeração.

Problemas de salinidade natural e induzida foram constatados no vale do Açu, havendo necessidade de estudos mais detalhados acerca de práticas de convivência com esses desvios, em alguns ambientes (Oliveira, 1988). Associando a qualidade das águas com a mineralogia dos solos, cuidados especiais devem ser tomados quando se usa irrigação em grande escala, para evitar problemas de acúmulo de sais, visto que a presença de minerais do tipo 2:1 nos solos pode acelerar o processo de salinização.

Os solos, pela textura, apresentam alto potencial de ascensão capilar e como tal, a presença do lençol freático acima de sua profundidade crítica pode resultar na aceleração do processo de salinização. As condições previstas, com relação a provável ascensão do lençol freático, são cruciais para tais solos. Em locais mais à jusante, no entanto, são diagnosticados solos geneticamente salinos (halomórficos, ou halobiomas), classificados como Solonchack Solonétzico. Em certos locais, solos classificados como Aluviais Eutróficos naturalmente apresentam problemas de salinidade. A alcalinidade moderada a elevada nesses ambientes pode provocar desequilibrios nutricionais nas culturas, o que pode converter-se em fator limitante da produção. Além dos efeitos prejudiciais diretos pelo sódio, nessa condição de alto $\mathrm{pH}$, pode ocorrer deficiência de micronutrientes e até mesmo de fósforo, embora com elevados teores no solo, determinados pelo extrator Mehlich-1 (Oliveira, 1988). 
As conseqüências de sais em solos se manifestam em problemas de salinidade, com o aumento da pressão osmótica do solo tendo efeito direto sobre as plantas que podem até desidratar-se; de sodicidade, causando dispersão das partículas do solo, diminuindo a permeabilidade e provocando encrostamento superficial e, de toxicidade, principalmente de sódio e cloro causando queima de folhas, diminuição na produtividade e morte de plantas.

Este trabalho teve como objetivo avaliar a eficiência de diferentes práticas de manejo de solos salino-sódicos na obtenção de melhorias em propriedades químicas e na produção de algodão e arroz, sob drenagem natural, na região do Baixo Açu-RN. 


\section{REVISÃO DE LITERATURA}

\subsection{Solos afetados por sais: origem, caracterização e dimensão do problema}

Solos afetados por sais existem em todos os continentes, sendo característicos no entanto, em zonas áridas/semi-áridas onde a evapotranspiração é maior que a pluviosidade. Szabolcs (1986) estima que aproximadamente $10 \%$ das terras do globo apresentam problemas de salinidade e/ou alcalinidade e que cerca de 10 milhões de hectares de terras irrigadas são abandonados a cada ano devido estes problemas. As maiores extensões de solos afetados por sais se encontram nos continentes: Australiano, Asiático e Sul-Americano (Tabela 1). Quanto ao Brasil, a estimativa de 4,5 milhões de hectares afetados corresponde apenas aos solos solonchack e solonetz. Pereira et al. (1985) referindo-se a levantamento do Serviço Nacional de Levantamento e Conservação de Solos (SNLCS), detalha as áreas de solos afetados por sais em sete Estados do Nordeste representando mais de 9,1 milhões de hectares (Tabela 2), sem incluir os perímetros irrigados e os solos aluvionais nos vales dos rios.

A salinidade do solo é medida pela condutividade elétrica no extrato de saturação (C.E $E_{\text {es }}$ ) e expressa em dS.m ${ }^{-1}$ (deci-Siemens por metro); a sodicidade é avaliada pela porcentagem de sódio trocável (PST) no Complexo de Troca Catiônica (CTC) do solo e a toxicidade de sódio e cloro pela concentração $\left(\mathrm{mmol}_{\mathrm{c}} \cdot \mathrm{L}^{-1}\right)$ destes elementos na solução do solo. A classificação do solo como salino e/ou sódico é feita a partir de valores de C. $E_{\mathrm{es}}$ e PST considerados críticos (Tabela 3), em alguma camada ou horizonte do solo, até 2,0m de profundidade (Estados Unidos, 1990).

Freqüentemente, uma PST de 10 a $15 \%$ se apresenta como nivel crítico. Nos solos arenosos, uma PST de $25 \%$ pode não mostrar efeito na estrutura e permeabilidade do solo; ao contrário, em solos argilosos uma PST de $5 \%$ já é considerada como alta, particularmente onde contém minerais de argila do tipo 2:1 (Gheyi \& Medeiros, 1991). 
Tabela 1 - Situação Mundial de solos afetados por sais

\begin{tabular}{|c|c|}
\hline LOCALIZAÇÃO & ÁREA (mil ha) \\
\hline$\overline{\text { AMERICA DO NORTE }}$ & 15.755 \\
\hline -Canadá & 7.238 \\
\hline -Estados Unidos & 8.517 \\
\hline MÉXICO E AMÉRICA CENTRAL & 1.965 \\
\hline- Cuba & 316 \\
\hline -México & 1.649 \\
\hline AMÉRICA DO SUL & 129.163 \\
\hline -Argentina & 85.612 \\
\hline -Bolívia & 5.949 \\
\hline -Brasil & 4.503 \\
\hline -Chile & 8.642 \\
\hline -Colômbia & 907 \\
\hline -Equador & 387 \\
\hline -Paraguai & 21.902 \\
\hline -Peru & 21 \\
\hline -Venezuela & 1.240 \\
\hline ÁFRICA & 80.538 \\
\hline -Etiópia & 11.033 \\
\hline -Chade & 8.267 \\
\hline -Egito & 7.360 \\
\hline -Nigéria & 6.502 \\
\hline -Botswana & 5.769 \\
\hline -Somália & 5.602 \\
\hline -Kênia & 4.858 \\
\hline -Sudão & 4.874 \\
\hline -Tanzânia & 3.537 \\
\hline -Argélia & 3.150 \\
\hline ASIA DO SUL & 84.838 \\
\hline -Iran & 27.085 \\
\hline -Índia & 23.796 \\
\hline -Paquistão & 10.456 \\
\hline -Iraque & 6.726 \\
\hline -Arábia Saudita & 6.002 \\
\hline -Afeganistão & 3.101 \\
\hline -Bangladesh & 3.017 \\
\hline ASIA CENTRAL E NORTE & 211.686 \\
\hline -União Soviética & 170.720 \\
\hline -China & 36.658 \\
\hline -Mongólia & 4.070 \\
\hline ASIA SUDESTE & 19.938 \\
\hline AUSTRÁlIA & 357.340 \\
\hline EUROPA & 50.804 \\
\hline TOTAL & 954.832 \\
\hline
\end{tabular}

Fonte: Szabolcs (1989). 
Tabela 2 - Áreas de solos afetados por sais em sete Estados do Nordeste do Brasil

\begin{tabular}{crrrrrrrr}
\hline & \multicolumn{7}{c}{ ESTADOS } & Area em 1000 ha \\
\cline { 2 - 9 } SOLO & CE & RN & PB & PE & AL & SE & BA & TOTAL \\
\hline Planossolo & 1.271 & 369 & 94 & 517 & 337 & 210 & 3.052 & 5.850 \\
Solonetz & 844 & 406 & 277 & 265 & 39 & 101 & 516 & 2.448 \\
Solonchack & 45 & 84 & - & - & - & - & - & 129 \\
Outros & 166 & - & - & - & 12 & 52 & 454 & 684 \\
TOTAL & 2.326 & 859 & 371 & 782 & 388 & 368 & 4.022 & 9.116 \\
\hline (\%) & 26 & 10 & 4 & 9 & 4 & 4 & 42 & 100 \\
\hline Adaptado & & & & & & & &
\end{tabular}

Adaptado de Pereira et al. (1985).

Tabela 3 - Valores limites de C.E $\mathrm{E}_{\text {es }}$ e PST para salinidade e sodicidade de solos.

\begin{tabular}{|c|c|c|c|}
\hline SOLO SALINO & SOLO SOLÓDICO & SOLO SÓDICO & \\
\hline C. $E_{\mathrm{es}}\left(\mathrm{dS} . \mathrm{m}^{-1}\right)$ & PST & PST & FONTE $^{1}$ \\
\hline$>4$ & $8<$ PST $<20$ & $\geq 20$ & Oliveira et al., (1992) \\
\hline$>4$ &. & $\geq 15$ ou $(\mathrm{RAS} \geq 13)$ & Estados Unidos (1990) \\
\hline $2<\mathrm{C} . \mathrm{E}_{\mathrm{es}} \leq 8 \mathrm{Lig} / \mathrm{med}$ & $7<\mathrm{PST} \leq 20$ & $>20$ & Pizarro, (1985) \\
\hline$>8$ Forte & - & - & Pizarro, (1985) \\
\hline
\end{tabular}

Quando a PST do solo é menor que $20 \%$, nas superficies internas das argilas predomina cálcio e nas externas o sódio que por sua vez aumenta a espessura da camada difusa e provoca dispersão. Quando a PST é maior que $20 \%$ o sódio também é adsorvido nas superficies internas e o mecanismo anterior se alia a expansão das argilas, provocada pelo grande raio de hidratação do sódio, favorecendo a dispersão (Pizarro, 1985).

Muitos dos problemas relacionados com excesso de sais e sódio trocável são inerentes ao solo no estado virgem. Entretanto. em diversas situações os solos são afetados por sais pela interferência do homem, ao que se denomina de salinização secundária. Pereira et al. (1985) afirmam que parte significativa dos solos afetados por 
sais no mundo, é de origem aluvional. Referindo-se as áreas irrigadas do Nordeste e relatando informações de Mello et al. ${ }^{1}$ os mesmos autores mencionam que os solos são na maioria, de origem aluvional, apresentando grandes variações nas características químicas e fisicas, tanto horizontal como verticalmente. Geralmente são de boa fertilidade, mas apresentam problemas de drenagem.

Os sais se originam principalmente das rochas pela ação de fatores do intemperismo entre os quais a água que também serve de transporte. Sob condições favoráveis de topografia (depressões), clima (evapotranspiração potencial maior que pluviosidade) e solos de baixa permeabilidade, os problemas de sais surgem naturalmente. Também, podem ser induzidos por um deficiente manejo da água de irrigação. Os sais podem ainda ser originados de depósitos fósseis, sendo trazidos à superficie pela elevação do lençol freático; como também, em zonas próximas ao mar podem ser levados pelo vento/chuvas e a longo prazo causar problemas.

Os processos de salinização e/ou sodificação secundária dos solos podem ocorrer por uma ou mais das seguintes condições: a) acumulação de sais provenientes de uma água de irrigação de alto teor de sais; b) elevação do nível de água subterrânea, que geralmente implica em: 1- aumento da salinidade das águas subterrâneas que se acumulam nas camadas profundas; 2- elevação do lençol freático, transportando sais das camadas profundas às camadas superficiais; 3- elevação do lençol freático, limitando a drenagem natural e dificultando a lavagem dos sais. c) falta ou deficiência de sistemas de drenagem nos solos irrigados.

Embora a intemperização dos minerais primários seja a fonte principal de quase todos os sais solúveis no solo, a fonte direta desses sais em solos irrigados é a própria água usada na irrigação e/ou o lençol freático (Richards, 1974). Em muitas situações o problema tem origem no manejo da irrigação haja visto que uma água considerada boa (C.E. $=0,75 \mathrm{dS} \cdot \mathrm{m}^{-1}$ ), intermediária entre as classes $\mathrm{C}_{1}$ e $\mathrm{C}_{2}$ de salinidade, quando aplicada num volume anual de apenas $10.000 \mathrm{~m}^{3} \cdot \mathrm{ha}^{-1}$, que corresponde a cerca de $55 \%$ do requerido por culturas como bananeira, deposita no solo cerca de 5 toneladas de

\footnotetext{
${ }^{1}$ MELLO, F.E.S.; BEZERRA, G.E.; GURGEL, E.A. Estudo de solos nos vales do Nordeste para fins de irrigação. Fortaleza, DNOCS, 1967. p. 7-38.
} 
sais/ano. Se o manejo é deficiente, se não existe fração de lavagem e se não há drenagem, naturalmente haverá um acúmulo de sais que a médio prazo poderá comprometer a exploração de culturas.

O semi-árido Nordestino tem como característica uma elevada insolação e em conseqüência uma alta evaporação que, em várias situações, corresponde a principal demanda de consumo de água dos reservatórios. Esse fenômeno provoca uma acumulação progressiva de sais nas águas de superficie às quais, se houver um favorecimento por parte da composição e grau de intemperismo das rochas na bacia de captação, abreviará a vida útil da qualidade da água do reservatório para irrigação. Quando o maior consumo de água de um reservatório se dá por evaporação ocorre processo de salinização progressiva da fonte que tende a piorar de classe de água para irrigação, com a idade da construção (Srinivasan et al., 1986).

O sistema de irrigação é um fator a ser considerado em potencial como agravante de problemas, dependendo da textura do solo. No caso da irrigação por aspersão, o impacto das gotas grandes pode destruir as partículas superficiais do solo e criar ou agravar os problemas de infiltração e produzir escoamento. Em irrigações normais a intensidade de aplicação varia de 3 a $6 \mathrm{~mm} \cdot \mathrm{h}^{-1}$ adaptando-se mais facilmente aos solos arenosos do que aos argilosos (Ayers \& Westcot, 1991). Em contrapartida, os sistemas por gotejamento se adaptam melhor aos solos argilosos, aplicam entre 2 e 4 L.h ${ }^{-1}$ de água, o que não afeta as partículas do solo (Ayers \& Westcot, 1991).

Quando uma área tem deficiência de drenagem, os sais se acumulam na zona radicular e/ou no lençol freático. Pizarro (1985) afirma que quanto maior é a concentração salina da água do solo, maior é a pressão osmótica que as plantas tem de superar para absorvê-la e pode chegar a um limite crítico em que a absorção de água para. Por esta razão, os sintomas de salinidade coincidem com os de seca. No entanto, com respeito ao solo, quanto maior a salinidade da água, menor será a espessura da camada difusa e menor a força de repulsão entre partículas, reprimindo dessa forma a dispersão.

A permeabilidade do solo está intimamente relacionada com a concentração de sais na água e porcentagem de sódio trocável (PST) no solo. 
Concentração de sal na água da ordem de $3 \mathrm{mmol}_{\mathrm{c}} \mathrm{L}^{-1}$ em solo com PST maior que 12 provoca uma redução na condutividade hidráulica do solo por dispersar a argila; o mesmo fato ocorre com água destilada em solo com PST de 1 a $2 \%$ (Shainberg et al., 1981; Freitas et al., 1984 e Sumner, 1992). Por esta razão, Shainberg et al. (1989) afirmarn que o efeito prejudicial do sódio é mais evidente durante a estação chuvosa do que durante a irrigação. Deduz-se portanto que em solos afetados por sais, medidas preventivas devem ser tomadas visando amenizar o efeito dispersivo causado pela água de chuva (praticamente sem sal). Resultados de diversos autores confirmam que quando a concentração de eletrólitos na solução superficial do solo é maior que $5 \mathrm{mmol}_{\mathrm{c}} \mathrm{L}^{-1}$ reduz-se a tendência de dispersão da argila, a taxa de infiltração é mantida alta e a formação de encrostamento é prevenida (Loveday, 1974; Agassi et al, 1982; Shainberg \& Letey, 1984; Shainberg et al, 1989 e Sumner, 1993).

\subsection{Uso de gesso para melhorias de solos salino-sódicos}

Para correção de solos salino-sódicos, pode se utilizar métodos químicos e/ou físicos. Os métodos químicos incluem o uso de corretivos na água de irrigação ou no solo e mistura ou mudança da fonte de água para irrigação. Os métodos fisicos se compõem de práticas culturais que manipulam o solo para aumentar sua taxa de infiltração, como: irrigação mais freqüente; preparo do solo (aração profunda, subsolagem); aumento no tempo de irrigação; sistematização do solo e uso de resíduos orgânicos (Ayers \& Westcot, 1976).

Pizarro (1985) classifica as técnicas de correção de solos com problemas de sais em fundamentais e auxiliares:

Fundamentais: Lavagem de sais e condicionadores químicos.

Auxiliares :- Técnicas mecânicas - aração profunda, subsolagem, mistura com areia, inversão de camadas.

- Técnicas biológicas - uso de resíduos orgânicos, cultivos de elevada evapo-transpiração.

- Técnicas elétricas. 
A correção de solos com problemas de sais é demorada e onerosa, principalmente quando se trata do processo de sodificação pois, além da lavagem do solo, há necessidade da aplicação de condicionadores. Assim, toma-se necessário definir práticas de manejo, que permitam a utilização do solo durante o período de recuperação.

A correção de solos salino-sódicos envolve essencialmente a aplicação de gesso seguido de lavagem dos sais. $\mathrm{O}$ gesso, cuja composição é $\mathrm{CaSO}_{4} \cdot 2 \mathrm{H}_{2} \mathrm{O}$ reage no solo deslocando o sódio dos pontos de troca para a solução conforme a reação:

$$
\text { Solo- } 2 \mathrm{Na}+\mathrm{CaSO}_{4} \Longleftrightarrow \text { Solo-Ca }+\mathrm{Na}_{2} \mathrm{SO}_{4}
$$

Para que as melhorias ocorram com mais rapidez é necessário uma boa drenagem do solo, facilitando a infiltração da água com lixiviação do sulfato de sódio.

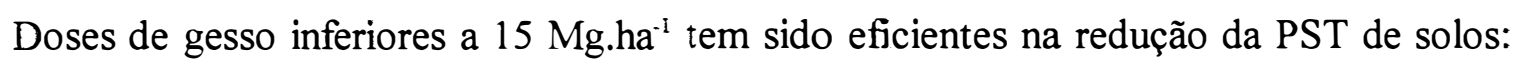
Abrol \& Bhumbla (1979) conseguiram baixar a PST de $84,5 \%$ para $17,5 \%$; Ferreyrah \& Coelho (1986) de 21,75\% para 10,7\%; Singh et al. (1989) de 93\% para 38\%; Armstrong \& Tanton (1992) de 19,5\% para 8\%; Santos (1995) de 19\% para 6,4\%, em intervalos de tempo variando de dois meses a dois anos. Cavalcante (1984) obteve uma redução da PST de um solo de $83 \%$ para $17,6 \%$ num período de 50 dias, com o uso de gesso agrícola em dose de $62 \mathrm{~g} \cdot \mathrm{kg}^{-1}$ de solo.

Existem diversas metodologias para estimar a necessidade de gesso para correção de solos sódicos: Schoonover ${ }^{2}$ citado por Richards (1974) recomenda agitar amostras do solo em solução saturada de $\mathrm{CaSO}_{4}\left(28 \mathrm{mmol}_{\mathrm{c}} \cdot \mathrm{L}^{-1}\right)$ determinando-se ao se estabelecer o equilíbrio o cálcio remanescente. Quando se conhece a CTC e a PST do solo, a necessidade de gesso pode ser calculada, à semelhança do método de saturação de bases para recomendação de calcário em solo ácido, para uma PST desejada, em uma determinada camada de solo.

A aplicação de gesso, tendo como base os métodos convencionais de recomendação em uso nos laboratórios, é também questionada para promoção de uma correção eficiente técnica e economicamente viável em áreas afetadas por sais (Oliveira, 1988). As complexas relações do ponto de vista teórico do equilíbrio químico entre as

${ }^{2}$ SCHOONOVER. W.R. Examination of soils for alkali. Berkley: University of California Extension Service, 1952. (mimeographed). 
fases sólida e a solução do solo, e as suas implicações com o desenvolvimento de plantas em ambientes salinos bem como o questionamento de um nível crítico de PST como arbitrário, ainda constituem pontos divergentes nos meios acadêmicos e técnicocientíficos, dificultando a aplicação dos modelos teóricos às condições de campo e a universalidade de conceitos (Shainberg \& Letey, 1984; Oliveira, 1988 e Sumner, 1993). Existe no entanto, um consenso de que o nível crítico de PST é aquele acima do qual o solo é afetado fisicamente. Alguns autores consideram o parâmetro Relação de Adsorção de Sódio (RAS), determinado na solução do solo, como mais adequado para caracterização dos solos sódicos (Shainberg \& Letey, 1984; Estados Unidos 1990 e Sumner. 1993).

O gesso é o condicionador químico mais usado para correção de solos sódicos, devido seu baixo custo, disponibilidade e fácil manuseio; diretamente previne o selamento superficial e a dispersão de partículas e indiretamente aumenta a porosidade, propriedades hidráulicas, drenagem e lixiviação e reduz a resistência à penetração em solos secos (Loveday, 1985). Na correção de solos sódicos, dois aspectos são de importância: a redução do sódio trocável e o aumento da concentração de eletrólitos na solução do solo. Ambos os requerimentos são freqüentemente conseguidos pela aplicação de gesso que tem a vantagem adicional de ser moderadamente solúvel, de fácil manuseio e disponibilidade e de baixo custo de aquisição (Shainberg et al., 1989 e Sumner. 1993). A substituição de sódio trocável por cálcio é um processo que requer a passagem de um fluxo de água através do solo. Se a permeabilidade do solo é limitada por camadas impermeáveis, pouco ou nenhum sódio será removido e a recuperação não ocorrerá (Ilyas et al., 1993).

$\mathrm{O}$ uso contínuo de fertilizantes nitrogenados acidificantes, em conjunto com uma fração da necessidade de gesso tem acelerado a recuperação de solos salinosódicos no Canadá (Carter e Pearen³ ${ }^{3}$ citados por Sumner, 1993).

\footnotetext{
${ }^{3}$ CARTER, M.R.; PEAREN, J.R. Amelioration of a saline-sodic with low applications of calcium and nitrogen amendments. Arid Soil Research and Rehabilitations, v.3, p.1-9, 1989.
} 
Silva (1978) afirma que a quantidade de cálcio trocável aumentou normalmente em um solo sódico, nos tratamentos de recuperação que receberam gesso, sendo que o aumento foi mais expressivo na camada de $0-15 \mathrm{~cm}$, onde se aplicou e incorporou o condicionador. Além do aumento de cálcio, Cavalcante (1984) e Lucena (1986) constataram aumento de sulfato e redução nos teores de sódio, carbonato, bicarbonato e cloreto, em solo salino-sódico, com uso de gesso agrícola. Aumentos nos teores de cálcio trocável no solo, decorrentes do uso do gesso, também foram constatados por Santos (1995).

A salinidade avaliada pela (C.E $E_{\text {es }}$ ) apresenta duplo comportamento em solos sob gessagem, aumentando (Gupta \& Bajpai, 1977 e Santos, 1995) ou diminuindo (Gupta \& Bajpai, 1977 e Gheyi et al., 1995). O gesso também contribui para diminuição do pH do solo (Gupta \& Bajpai, 1977; Singh \& Singh, 1989; Dubey \& Mondal, 1994 e Santos, 1995). Em dose correspondente a $40 \%$ da necessidade para correção de um solo salino sódico favoreceu para redução de pH, C.E es e PST (Lucena, 1986) bem como, pode provocar redução no magnésio trocável (Armstrong \& Tanton, 1992 e Santos, 1995).

O gesso (14 Mg.ha $\left.{ }^{-1}\right)$ foi mais efetivo que o esterco de curral $\left(30 \mathrm{Mg}^{-h^{-1}}\right)$ na redução da sodicidade do solo diminuindo a PST para 32\% enquanto com esterco ficou em $43 \%$ e na testemunha absoluta em $68 \%$ (Singh \& Singh, 1989). A aplicação conjunta de gesso (12,5 Mg.ha $\left.{ }^{-1}\right)$ e esterco de curral (30 Mg.ha $\left.{ }^{-1}\right)$ favoreceu para um maior decréscimo de sódio trocável no solo (Dubey \& Mondal, 1994). Por outro lado, após 21 meses da aplicação de gesso (30 Mg.ha $\left.{ }^{-1}\right)$, esterco (16 Mg.ha- $\left.{ }^{-1}\right)$ e ácido sulfúrico (1,2 Mg. ha $\left.{ }^{-1}\right)$ em solo salino sódico do Estado da Paraíba, Gheyi et al. (1995) concluíram que houve uma acentuada diminuição da PST do solo, independente do uso de condicionadores.

A eficiência do gesso parece não atingir camadas profundas do perfil do solo. El Mowelhi et al. ${ }^{4}$, citados por Pereira et al. (1985), observaram que a zona de ação

\footnotetext{
${ }^{4}$ EL MOWELHI, N.M.; SHARAF EL-DIN, F.; BADAWI, R.M. Effect of drainage, subsoiling and gypsum application on improving sodic soil of Egypt. Agricultural Research Review, v.54, p.920, 1976.
} 
do gesso como melhorador, praticamente não se estendia além da profundidade onde era colocado. Dificilmente são observados efeitos em profundidades maiores, mesmo com subsolagem relata Silva (1978).

Com relação ao tempo de ação do gesso Alawi et al. ${ }^{5}$ citados por Pereira et al. (1985) constataram que a eficiência do gesso desaparecia no segundo ano devido, provavelmente à precipitação do cálcio solúvel. Entretanto, Rasmussen et al. (1972) observaram efeito residual do gesso até o quarto ano após a aplicação.

Abrol et al. (1975), analisando os resultados obtidos quando aplicaram gesso a solos com problemas de sais, superficialmente e misturado em profundidade, observaram que a aplicação superficial aumentou em cerca de 18 vezes o valor da condutividade hidráulica em relação a condição de mistura do condicionador ao solo. Melhorias na condutividade hidráulica em camadas de até $40-60 \mathrm{~cm}$ de profundidade foram observadas por Ilyas et al. (1993) após um ano da incorporação de $25 \mathrm{Mg}$ ha $^{-1} \mathrm{de}$ gesso, na camada de $0-20 \mathrm{~cm}$.

Shainberg \& Letey (1984) afirmarn que a condutividade hidráulica do solo depende da PST e da concentração de sais da solução percolada, podendo ser preservada mesmo em altos valores de PST desde que a concentração salina da água esteja acima de determinado nível crítico. Por outro lado, solos mesmo com baixa PST podem dispersar e perder permeabilidade, se for utilizada água com concentração de sais abaixo de 1

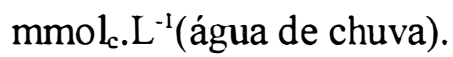

Melo et al. (1988) estudando o efeito do gesso e da concentração salina da água na condutividade de um solo saturado, verificaram que os valores obtidos com a aplicação da solução de maior concentração salina era de cinco a dez vezes mais elevados que os obtidos com a aplicação de gesso. Ayers \& Westcot (1991), considerando que o problema de infiltração induzido pela qualidade da água de irrigação está situado na camada superficial do solo, ressaltam que as aplicações de gesso em quantidades

\footnotetext{
"ALAWI, B.J.; STROEHLEIN, J.L.; HANLONJUNIOR, E.A.; TURNER JUNIOR, F. Quality of irrigation water and effects of sulfuric acid and gypsum on soil properties and sudangrass yields. Soil Science, v.129, p.315-9, 1980.
} 
relativamente pequenas são mais eficazes quando o corretivo é deixado na superficie ou incorporado nos primeiros centímetros do solo.

A dissolução de gesso na superficie do solo irá liberar eletrólitos suficientes para prevenir a dispersão de argila e o declínio da condutividade hidráulica do solo na superficie e dentro do perfil. Assim, freqüente aplicação (uma vez por ano, antes da estação chuvosa) de pequenas quantidades de gesso, preferencialrnente gesso agrícola, pela mais fácil dissolução, pode ser uma ótima prática (Shainberg et al., 1989). Agassi et al. (1982) observaram que espalhando gesso sobre o solo foi mais benéfico do que incorporando-o a uma profundidade de $5 \mathrm{~mm}$.

Keren \& Shainberg (1981) mencionam que na recuperação de solos sódicos duas fontes principais de gesso são utilizadas: o proveniente de minas (natural) e o industrial (gesso agrícola), subproduto da industria de fosfatos. Os mesmos diferem quanto a densidade do produto e condições de sedimentação que por sua vez afetam a taxa de dissolução do gesso em solução e influem na eficiência como melhorador do solo. A solubilidade do gesso aumenta na presença de $\mathrm{NaCl}$, com coeficiente de dissolução a $0,1 \mathrm{~N}$ de 1,45 vezes em relação a água pura. Comparando as duas fontes de gesso os autores observaram que a taxa de dissolução do gesso agrícola foi maior do que a do gesso de mina. O tempo para atingir 50\% de solução saturada de cálcio com o gesso de mina foi 9 vezes maior que com o gesso agrícola e este foi mais efetivo em manter mais elevada a velocidade final de infiltração de água no solo. No que se refere a disponibilidade do gesso agrícola no Brasil, PETROFÉRTIL espera que o uso do gesso... (1992) informa que na época existiam cerca de 25 milhões de toneladas de gesso agrícola prontas para serem retiradas, gratuitamente, nas fábricas da Fosfértil, pagando-se apenas o transporte.

Quando a irrigação é substituída pela chuva, excessos de sais são lixiviados e o solo geralmente impermeabiliza como resultado da formação de crostas. Para prevenir essa condição durante a estação chuvosa, uma prévia adição de gesso agrícola é recomendável (Frenkel \& Hadas, 1981). Gesso agrícola na dose de $5 \mathrm{Mg}$.ha- ${ }^{-1}$ reduziu o escorrimento superficial de 22,8 para 3,8 $\mathrm{mm}$ e de 64,2 para $18,7 \mathrm{~mm}$ em solos com PST respectivamente de 4,6 e 19,3\%. O gesso agrícola mantém rápida penetração 
de água por dois mecanismos: dissolve-se fácil fornecendo eletrólitos que floculam as partículas do solo e libera sais de cálcio que substitui o sódio trocável diminuindo a tendência a dispersar as argilas.

Sob condições de solo sódico a infiltração acumulada (24 horas) aos dezoito meses da gessagem, aumentou com a dose; partindo da testemunha com 22,9 mm

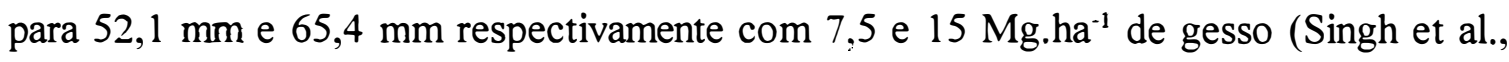
1989). A gessagem trouxe melhorias na retenção de umidade no perfil do solo, que após infiltração variou de 19 a $11 \%$ na testemunha, de 21 a 13,5\% com 7,5 Mg.ha-1 de gesso e

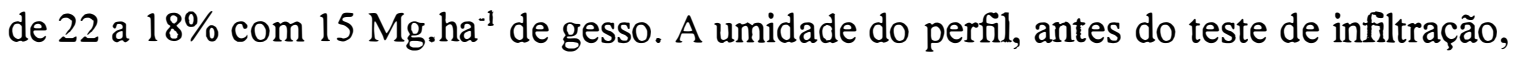
a partir dos $30 \mathrm{~cm}$ de profundidade, teve um comportamento muito influenciado pela gessagem que, na maior dose reteve mais de $40 \%$ de água à $60 \mathrm{~cm}$ em relação à testemunha e, a partir de $90 \mathrm{~cm}$, praticamente dobrou.

Em solo sódico de textura argilosa com infiltração de $292 \mathrm{~mm}$ de água

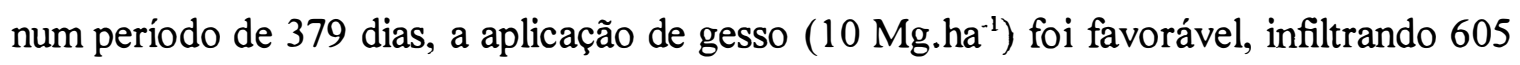
mm em 145 dias e mantendo úmido o perfil do solo a maiores profundidades (McIntyre, 1979). O aumento de lixiviação de sais solúveis pela drenagem após a aplicação do gesso, no citado experimento, ocasionou a descida de cloro, observando-se acumulação em profundidades de $1 \mathrm{~m}$, sem gesso e a $2,8 \mathrm{~m}$, com gesso.

Aumentos significativos de condutividade hidráulica, progressivos com doses de gesso, porém pouco expressivos por limitações de tempo (60 dias) foram obtidos por Freitas et al. (1984) em solo salino sódico do vale do Curu no Ceará onde observaram maior eficiência do corretivo em maior PST do solo.

\subsection{O preparo do solo em áreas afetadas por sais}

A aração profunda em terras irrigadas com problemas de sódio parece ser uma prática econômica e eficiente, com amplas melhorias nas condições fisicas em geral, recuperando as áreas salino-sódicas improdutivas. Quando associada a gessagem reduziram os teores de sais solúveis e a PST do solo a níveis adequados em toda a zona radicular, num período de 2 a 3 anos de cultivo (Rasmussen et al., 1972). As arações profundas estimulam e favorecem bastante a infiltração e aceleram o processo de 
correção de solos afetados por sais, mesmo que não utilizem condicionadores. Solos que tem $\mathrm{CaCO}_{3}$ no perfil como única fonte de cálcio tem sido recuperados satisfatoriamente com aração profunda e irrigação (Rasmussen \& McNeal, 1973).

As práticas mecânicas no entanto, apresentam eficiência de curta duração, pelo que devem ser consideradas unicamente como soluções temporárias (Ayers \& Westcot, 1991). As subsolagens rompem as camadas impermeáveis, melhorando assim a permeabilidade do solo. Seu efeito porém é de uma duração limitada a um ou dois anos (Gheyi \& Medeiros, 1991).

Silva (1978) em trabalho desenvolvido em solo sódico do perímetro irrigado de São Gonçalo- PB concluiu que a PST e a condutividade elétrica do extrato de saturação do solo diminuíram de maneira mais acentuada na área subsolada do que na área com preparo tradicional. El Mowelhi et al. ${ }^{6}$, citados por Pereira et al. (1985), afirmam que obtiveram melhores resultados quando combinaram drenagem e subsolagem à aplicação do gesso, relatando que o uso de mais de um tratamento acelera o processo de correção de solos sódicos.

\subsection{Uso de resíduos orgânicos e cultivo de plantas tolerantes em solos afetados por sais}

A utilização de plantas tolerantes a sais parece ainda constituir a solução mais viável econômica e ecologicamente, caracterizando a prática de convivência com o problema da salinidade (Oliveira, 1988). Em áreas com salinidade elevada, algumas culturas não conseguem desenvolver-se plenamente. Nestes casos, a opção adotada pelos pequenos produtores do vale do Açu tem sido o uso de plantas forrageiras que naturalmente se desenvolvem.

O principal objetivo na seleção de procedimentos de manejo para recuperação e controle de solos salino-sódicos é reduzir a concentração de sais solúveis e de sódio trocável no perfil do solo a um nível não prejudicial a maioria das culturas. A correção dos solos afetados por problemas de infiltração é necessária, quando a velocidade com que a água atravessa a superfície do solo é tão lenta que não permite

\footnotetext{
${ }^{6}$ EL. MOWELHI et al., op. cit., p.12.
} 
suprir a demanda das culturas ou lixiviar os sais acumulados na zona radicular (Ayers \& Westcot, 1991).

A permeabilidade de solos com inadequada drenagem interna pode ser melhorada por cultivos de plantas com sistema radicular profundo e capazes de tolerar altas concentrações de sais e condições de inundação (Ilyas et al., 1993). Em condições inundadas o $\mathrm{pH}$ dos solos converge para a neutralidade, aumenta a solubilidade do fósforo e a concentração das bases na solução do solo (Ponnanperuma, 1964). A decomposição da matéria orgânica sob inundação tem entre os produtos finais o dióxido de carbono e o hidrogênio que promovem o abaixamento do $\mathrm{pH}$ em solos sódicos e calcários.

Quando a matéria orgânica é usada como condicionador químico de um solo sódico os mecanismos que envolvem o processo de recuperação, sob condições inundadas, são: (1) decomposição da matéria orgânica, liberação de sais e evolução de $\mathrm{CO}_{2}$ e certos ácidos orgânicos; (2) diminuição do $\mathrm{pH}$ e liberação de cátions pela solubilização de $\mathrm{CaCO}_{3}$ e outros minerais, aumentando a condutividade elétrica; (3) substituição do sódio pelo cálcio e magnésio e diminuição da PST (Puttaswamygowda \& Pratt, 1973). Entre diversos produtos orgânicos testados por esses autores o melhorador mais benéfico foi o esterco de curral.

Almeida (1994), utilizando vinhaça como substituta da água de irrigação para lixiviação de sais em solo salino-sódico proveniente de São Gonçalo-PB, afirma que o uso desse resíduo poderia dispensar a incorporação de outros condicionadores na recuperação do solo porém, acrescenta, que diminuições mais acentuadas de pH, C.E. e sódio trocável foram obtidas quando aplicou a vinhaça no solo em associação com gesso. A contribuição de resíduos orgânicos: palha de carnaúba, casca de arroz e feno de feijão de porco foi pouco expressiva no movimento de água em solo salino sódico do vale do Curu no Ceará (Freitas et al., 1984).

Para que as aplicações de resíduos orgânicos sejam eficientes, necessitamse de quantidades de 10 a $30 \%$ do volume do solo nos seus primeiros $15 \mathrm{~cm}$ (Ayers \& Westcot, 1991). Os resíduos mais eficazes são os que não se decompõem com rapidez e mantém a porosidade do solo mediante rachaduras e espaços vazios. A aplicação em 
grandes quantidades entretanto, pode trazer conseqüências negativas, como desequilíbrios nutricionais, aumento de salinidade produzido por resíduos com sais, falta ou excesso de nitrogênio provocados por certos resíduos (serragem ou esterco) e toxicidade (por cloreto e potássio da casca de arroz) (Ayers \& Westcot, 1991). Os resíduos de plantas halófitas se constituem em fonte de sais que através do processo biológico podem contribuir para a salinização de solos e águas, particularmente em regiões áridas (Kovda e Minashina ${ }^{7}$ citados por Szabolcs, 1989).

Abrol \& Bhumbla (1979) trabalhando com arroz irrigado por inundação verificaram que mesmo sem uso de gesso a PST do solo foi reduzida de $87 \%$ para $50 \%$ na camada de $15 \mathrm{~cm}$ e de $94 \%$ para $63 \%$ em $15-30 \mathrm{~cm}$ do solo. Os autores relatam que a presença das raízes de arroz no solo cria canais que resultam em aumento da permeabilidade assegurando a subsequente lixiviação. A inclusão do arroz na rotação pode intensificar a recuperação de solos com alta sodicidade. A alta tolerância do arroz à sodicidade é atribuída ao seu sistema radicular superficial e a manutenção de uma lâmina de água no campo, durante o desenvolvimento da cultura. Sob contínua inundação, ocorre abaixamento de $\mathrm{pH}$ e fatores limitantes ao crescimento das culturas são reduzidos pela evolução de grandes quantidades de $\mathrm{CO}_{2}$ das raizes e atividade bacteriana, que são acumulados devido a restrita difusão. Abrol \& Bhumbla (1979) observaram que durante o crescimento do arroz, a PST do solo foi consideravelmente reduzida tanto em superficie como em camadas sub-superficiais demonstrando que a cultura pode auxiliar na correção mais rápida e a maiores profundidades do solo. Conforme Ghassemi et al. (1995) os solos sódicos podem ser corrigidos pelo uso de grande volume de água de irrigação associado a uma boa prática de cultivo porém, o processo é lento e pode ser acelerado pelo uso de produtos químicos.

$\mathrm{O}$ arroz na Índia é explorado em cultivo irrigado por inundação. Nesta condição muitas alterações químicas ocorrem, uma delas é o abaixamento do pH de solos sódicos. Assim é possível assegurar um bom cultivo de arroz mesmo com uma menor quantidade de gesso. Foram testadas frações da necessidade de gesso para

${ }^{7}$ KOVDA, V.A.; MINASHINA, N. G. (eds). Irrigation and drainage of salt-affected soils (Russian). Izd. Nauka: Moscou, 1967. 
correção do solo, em intervalos de $20 \%$. O pH do solo após o primeiro cultivo do arroz mostrou uma seqüência de redução com o aumento da dose de gesso. A condutividade elétrica decresceu acentuadamente com o cultivo do arroz como conseqüência da lixiviação de sais (Shahi et al., 1978).

O arroz é a principal cultura utilizada em solos com excesso de sódio em processo de recuperação nos países tropicais. Entretanto, de acordo com Pereira et al. (1985), os resultados são os mais variados. Além do arroz, gramíneas forrageiras (capins) também reduzem a sodicidade do solo promovendo uma facilidade indireta na remoção de sódio trocável pelo acréscimo de permeabilidade decorrente do aumento de área de poros condutores (Singh \& Singh, 1989).

\subsection{Influência de técnicas de correção na produção vegetal}

A sodicidade pode afetar o desenvolvimento radicular quando o $\mathrm{pH}$ do subsolo é alto. Experiências com culturas em solução tem mostrado que o crescimento de raízes cessa em valores de $\mathrm{pH}$ ao redor de 9,0; todavia, não está claro se em $\mathrm{pH}$ de 9,0 a 9,5 em condições de campo o crescimento de raizes irá parar (So \& Aylmore, 1993). A sodicidade no entanto pode afetar indiretamente $o$ desenvolvimento de raízes pela elevada resistência do solo a penetração, associada a compactação e redução no armazenamento de água.

O sódio, causando o encrostamento superficial do solo pode acarretar mais um efeito adverso, de natureza biológica, dificultando a emergência de plântulas. A semente germina mas a plântula não consegue emergir por não ter condições de romper a crosta formada que se constitui num impedimento mecânico superior, causador de redução na população de plantas em áreas afetadas. Alguns produtores do semi-árido costumam, em solos afetados por sais, cobrir as sementes com areia, evitando o selamento na cova ; outros, plantam um elevado numero de sementes por cova de modo a aumentar a pressão de ruptura favorecendo a emergência das plântulas que "estouram" a crosta em blocos tipo "tapioca". Ambas as medidas apresentam vários inconvenientes e poderão ser úteis apenas em pequenas áreas com reduzido índice tecnológico de 
exploração. Impedindo a formação de crosta superficial no solo através da gessagem em superficie, os problemas de emergência de plântulas são solucionados, conseguindo-se populações de plantas mais elevadas e uniformes por área (Bennett et al., 1964; Loveday, 1974 e Shainberg et al., 1989). O gesso aumentou a emergência de algodão em solo da Geórgica (EUA), de $10 \%$ para 50\%, com concomitante diminuição de resistência do encrostamento (Bennett et al., 1964) enquanto, na Austrália, Loveday (1974) mostrou que existe uma relação geral entre resistência da crosta, emergência e condutividade hidráulica em solos dispersivos e demonstrou aumentos de $100 \%$ na emergência de sementes com o uso de gesso.

Os rendimentos de arroz aumentaram consideravelmente com $20 \%$ da recomendação de gesso, no primeiro cultivo e, os aumentos declinaram, com doses superiores. Três anos após, melhorias no rendimento de arroz foi constatada mesmo na testemunha justificando-se por mudanças nas condições fisicas e químicas em conseqüência das irrigações por inundação para exploração da cultura (Shahi et al., 1978). Uma dose de gesso agrícola correspondente a $40 \%$ da necessidade para correção de um solo salino-sódico foi a que se mostrou mais eficiente no aumento de crescimento e produção de matéria seca de feijão e sorgo (Lucena, 1986).

Em pesquisas na Índia foram obtidos incrementos superiores a $400 \%$ na produtividade de arroz com o uso de gesso entretanto, Pereira et al. (1985) não obtiveram aumento de produtividade da cultura, em solo com PST de $53 \%$, em função do gesso aplicado nas doses de 13 e $26 \mathrm{Mg} \cdot \mathrm{ha}^{-1}$ e incorporado até a profundidade de $30 \mathrm{~cm}$. Da mesma forma, na recuperação de solo salino-sódico da Paraiba, Gheyi et al. (1995),

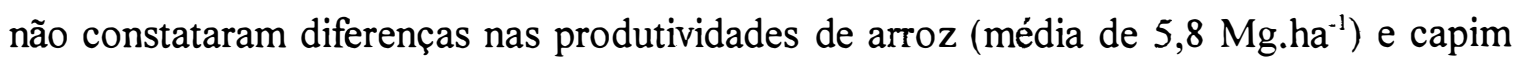
(29,3 a 36,6 Mg.ha ${ }^{-1}$ ) com o uso de condicionador químico (gesso $30 \mathrm{Mg}^{-h^{-1}}$; ácido

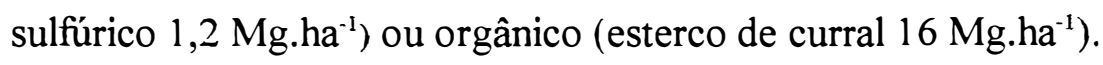

Após um ano de aplicação do gesso, com o arroz correspondendo ao terceiro cultivo de uma rotação, foi observado aumentos de produtividade no intervalo de 41 a $61 \%$ todavia, decorridos 2 anos, no quinto cultivo da rotação, foram obtidas elevadas produtividades de arroz mesmo sem gesso. Não foi constatada redução nos rendimentos do arroz a uma PST de 55\%, mostrando que a cultura é altamente tolerante 
a condições de elevada sodicidade. Também foi observado que o arroz rendeu próximo do máximo, mesmo quando a PST da camada de $15-30 \mathrm{~cm}$ foi da ordem de $80 \%$ (Abrol \& Bhumbla, 1979).

Gesso (14 Mg.ha ${ }^{-1}$ ) e esterco de curral (30 Mg.ha ${ }^{-1}$ ), promoveram aumentos altamente significativos nos rendimentos de arroz (Singh \& Singh, 1989). A aplicação de gesso (12,5 Mg.ha $\left.{ }^{-1}\right)$ associada a esterco de curral (30 Mg.ha $\left.{ }^{-1}\right)$ possibilitou a obtenção de rendimento de arroz $\left(4,6 \mathrm{Mg} \cdot\right.$ ha $\left.^{-1}\right)$ superior aos obtidos com os mesmos condicionadores sozinhos (Dubey \& Mondal, 1994).

A lavagem de sais em área subsolada resultou em produção de arroz mais elevada (Silva, 1978). Ferreyrah \& Coelho (1986) estudaram efeito de quatro doses de

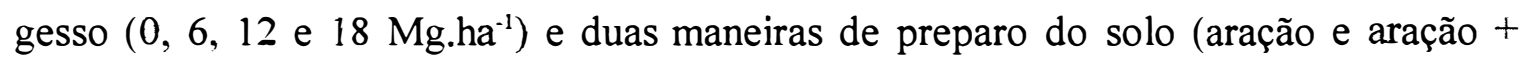
subsolagem) na produtividade de arroz, num solo com problema de sodicidade e concluíram que os tratamentos com subsolagem e gesso (6 e $12 \mathrm{Mg}^{-h^{-1}}{ }^{-1}$, incrementaram a produtividade do arroz enquanto a aplicação de $18 \mathrm{Mg} \mathrm{ha}^{-1}$ de gesso provocou efeito depressivo sobre o rendimento da cultura. A subsolagem possibilitou a obtenção de melhores rendimentos de arroz (4.683 a $5.735 \mathrm{~kg} \mathrm{ha}^{-1}$ ) em solo sódico do vale do CuruCE. em razão do rompimento da camada impermeável favorecer o movimento de água $\mathrm{e}$ a atividade radicular (Costa et al., 1990). 


\section{MATERIAL E MÉTODOS}

\subsection{Descrição e caracterização da área geográfica}

A região do baixo curso do Rio Piranhas-Açu (Baixo Açu) está localizada na parte Centro-Sul da bacia Potiguar (RN), situando-se em torno de $6^{\circ}$ de latitude sul e $38^{\circ}$ de longitude oeste, iniciando-se praticamente na interface entre a referida bacia e a formação Cristalino, limitada aproximadamente pela cidade de Açu, ao Sul e o município de Pendências, ao Norte, numa distância de mais ou menos $45 \mathrm{~km}$. A região é circundada pela formação Calcário Jandaíra e contém praticamente a totalidade dos depósitos aluvionais contínuos do Rio Açu, que se encontram situados numa extensão de uns 25 $\mathrm{km}$, até a altura de Carnaúbais, onde o aluvião perde sua continuidade.

O Baixo Açu tem uma área de influência de cerca 878.200 ha, composta por 11 municípios. Os municípios mais diretamente envolvidos são: Jucurutu, São Rafael, Ipanguassu e Assu, sendo os dois primeiros pela área inundada da barragem Armando Ribeiro Gonçalves e os dois últimos pelos projetos de irrigação que ali se desenvolvem. O programa de irrigação para o Vale tem como centro o município de Ipanguassu, que possui mais de 10.000 ha de aluviões (Yap-Salinas \& Brito, 1982).

De acordo com BRASIL (1978) a região do Açu está incluída dentro da Zona Hidrologicamente Homogênea (ZHH) II, cuja extensão é estimada em $263.966 \mathrm{~km}^{2}$, abrangendo não só a bacia do Açu, como também a dos rios Mossoró, Apodi, Jaguaribe, parte da bacia do Acaraú, no Ceará e inclusive parte da bacia do São Francisco, em Pernambuco e Bahia. Tal abrangência dá uma boa dimensão da representatividade da área em questão, uma vez que é preocupante uma possível ruptura do equilibrio hidrológico que poderá ocorrer com o avanço da irrigação. 


\subsection{Aspectos climáticos da região do Baixo Açu}

Com respeito a pluviometria, a área de influência do Baixo Açu encontrase na faixa de isoietas entre 450 a $600 \mathrm{~mm}$ anuais (média de $570 \mathrm{~mm}$ ), sendo os valores extremos observados de $1.414 \mathrm{~mm}$ e $96,4 \mathrm{~mm}$. Do ponto de vista de distribuição, a maior parte das chuvas $(79 \%)$ ocorre nos meses de fevereiro, março, abril e maio, que compreendem o quadrimestre mais úmido, em contraste com os meses de agosto, setembro, outubro e novembro, que constituem o quadrimestre mais seco (2\%). Em termos de comportamento da pluviosidade, existe a probabilidade de ocorrência em 10\% dos anos, de precipitação igual ou superior a $940 \mathrm{~mm}$, entre os meses de janeiro a julho.

Quanto a temperatura, a média anual para Açu registra $27^{\circ} \mathrm{C}$, a média mensal mais alta ocorre em janeiro e alcança $29^{\circ} \mathrm{C}$, enquanto a mais baixa ocorre em junho, com $26,4^{\circ} \mathrm{C}$, mostrando regularidade marcante, dentro de uma amplitude muito estreita (de $2,6^{\circ} \mathrm{C}$ ao ano). A umidade relativa estimável média para Assu é de $65 \%$. Com base em dados de zonas vizinhas, pode-se inferir por estimativa, uma insolação total anual de 3.000 horas de brilho solar, com média diária de 8,2 horas. De acordo com YapSalinas \& Brito (1982), a evaporação anual média (tanque classe A), com base em dados do município de Apodi, atinge $3.006 \mathrm{~mm}^{-a n \mathrm{~N}^{-1}}$. A Evapotranspiração Potencial (ETP) estimada pela equação de Hargreaves é de $1.951 \mathrm{~mm}$ anuais, com um coeficiente de correção entre o tanque e a ETP de 0,65 (média anual).

Do ponto de vista climático chama a atenção a diferença entre o valor médio da precipitação para Assu $(570 \mathrm{~mm})$ e uma evapotranspiração anual estimada em $1.951 \mathrm{~mm}$. A distribuição das chuvas oferece uma clara idéia da resultante climática que influencia a direção do movimento de água, caso esta fosse disponível no solo. Por outro lado, observa-se uma pequena flutuação na temperatura ao longo do ano, o que permite inferir uma constância de valores de evaporação e insolação, cujos índices estão na faixa de $3.006 \mathrm{~mm}$ e 3.000 horas de sol por ano, respectivamente.

\subsection{A Formação Aluvional da Região do Baixo Açu}

Uma manifestação tectônica de caráter local, ocorre no vale do Açu nas proximidades de Carnaúbais; a espessura do aluvião indica uma profundidade de $114 \mathrm{~m}$ de 
depósito aluvional em repouso direto sobre o manto superior da formação Açu (sem a presença local do calcário). Nesta área o vale se contrai expressivamente, a formação Jandaíra aflora em ambos os lados (encostas) e sua ausência, embaixo do aluvião, é uma indicação de que, pelo menos nesse trecho o vale apresenta um estrangulamento (YapSalinas \& Brito, 1982)

A formação aluvional é de composição lítica bastante variável, em geral composta de siltes e argilas escuras e cinzentas, areias argilosas e areias puras de granulações fina, média e grossa. Os perfis mostram alternância das camadas argilosas e areias puras de permeabilidade elevada. A formação aluvional tende a variar em espessura, aumentando em direção ao Norte; na altura de Ipanguassu, registros de poços indicam uma espessura de $20 \mathrm{~m}$, chegando a um extremo (localizado) de $114 \mathrm{~m}$, na altura de Carnaúbais. O substrato impermeável corresponde ao manto superior argiloso da formação Açu (Yap-Salinas \& Brito, 1982).

A planície aluvional do Açu alcança $15 \mathrm{~km}$ de largura, em Ipanguassu e 3 $\mathrm{Km}$ na localidade de Estreito. A partir do município de Alto do Rodrigues, a extensão dos aluviões cresce suavemente, indo alcançar $25 \mathrm{~km}$ na altura da linha atual da costa Atlântica. Ao longo desta última parte do vale, desenvolve-se a indústria salineira de Macau, que cobre os últimos $2 / 3$ daquele setor. No terço superior, manifesta uma interfase de água doce água salina, onde a altura da água doce é de 2 a $3 \mathrm{~m}$ acima da água salgada. $\mathrm{O}$ aqüífero apresenta águas cloretadas-sódicas, e mistas, com concentrações de sais de 500 a $1.000 \mathrm{mg} \cdot \mathrm{L}^{-1}$. A intrusão salina avança até uma distância equivalente ao ponto médio entre Estreito e Alto do Rodrigues. As constantes hidrodinâmicas atribuídas a este aqüífero são: Coeficiente de transmissividade: $10^{-3}$ a $3 \mathrm{x}$ $10^{-3} \mathrm{~m}^{2} \cdot \mathrm{s}^{-1}$ e $25 \%$ de Porosidade efetiva (Yap-Salinas \& Brito, 1982).

$\mathrm{Na}$ área em estudo encontram-se solos originados pelas formações quatemárias recentes, de alta fertilidade mas com freqüentes problemas de sais, entre os quais tem-se os solos aluviais eutróficos com caráter salino-sódico. É nos aluviões onde prolifera a vegetação de mata ciliar de carnaúbas, enquanto ao redor desses solos de baixadas situam-se os tabuleiros com caatinga hiperxerófila (Yap-Salinas \& Brito, 1982 e Oliveira, 1988). 
As flutuações do nível freático no aluvião são da ordem de $2 \mathrm{~m}$ durante $\mathrm{o}$ ciclo hidrológico presente. Os níveis máximos em Ipanguassu estão aproximadamente em $4 \mathrm{~m}$, enquanto na época mais seca se localizam em torno de $6 \mathrm{~m}$, podendo-se adotar uma espessura média de $5 \mathrm{~m}$ do perfil, com uma porosidade drenável média de 10\% (YapSalinas e Brito, 1982).

\subsection{Histórico da área experimental}

O Plano Experimental desenvolvido no Baixo Açu-RN, situa-se em área de influência da maior bacia hidrográfica do Estado (Piranhas-Açu) onde localiza-se a barragem Armando Ribeiro Gonçalves com capacidade de armazenamento de 2,4 bilhões de $\mathrm{m}^{3}$ de água. $\mathrm{O}$ potencial de terras irrigáveis do vale é superior a 20.000 ha incluindo solos aluviais e de tabuleiros, sendo os primeiros de alta fertilidade, próximos da captação de água porém, com limitações causadas por sais, enquanto os de tabuleiros são de baixa fertilidade, distantes da captação de água mas, com a vantagem de serem arenosos, profundos e muito bem drenados, sem limitações de ordem física.

No Vale do Açu, várias Empresas Agrícolas se instalaram nos últimos 10 anos (FRUNORTE, AGRO-KNOLL, SÃO JOÃO, FINOBRASA etc.) com Projetos de irrigação voltados principalmente para fruticultura. Inicialmente optaram pelas áreas aluvionais e posteriormente pelas de tabuleiros, onde existem mais de 3.000 ha irrigados. A migração dos empreendimentos das áreas aluvionais para os tabuleiros se deu em decorrência de problemas com o manejo das terras aluvionais. Esse processo de ocupação das terras modificou a estrutura agrária em toda a área de influência da região do Baixo Açu (Silva, 1992).

A Empresa de Pesquisa Agropecuária do Rio Grande do Norte (EMPARN), em convênio com o DNOCS, recebeu 95 ha de solos aluviais, no município de Ipanguassu-RN dos quais, em levantamentos realizados, pelo menos 20 ha estão afetados por sais. Foi selecionada uma área representativa de solo salino-sódico para condução dos trabalhos (Tabelas 4 e 5), cuja velocidade de infiltração de água quase se anula após uma hora de teste (Figura 1). A densidade do solo em camadas de até 30$60 \mathrm{~cm}$ de profundidade é da ordem de $1,27 \mathrm{Mg} \cdot \mathrm{m}^{-3}$ o solo é de textura franco siltosa e a 
retenção de água a $0,01 \mathrm{MPa}$ e a $1,5 \mathrm{MPa}$, respectivamente de 0,385 e $0,175 \mathrm{~kg} \cdot \mathrm{kg}^{-1}$ de solo.

Tabela 4 - Caracterização física, teor inicial de cátions solúveis e níveis de salinidade no perfil do solo aluvial salino-sódico de Ipanguassu, RN.

\begin{tabular}{|c|c|c|c|c|c|c|c|c|}
\hline \multirow[t]{2}{*}{$\begin{array}{l}\text { PROF. } \\
(\mathrm{cm})\end{array}$} & \multicolumn{3}{|c|}{$\begin{array}{l}\text { GRANULOMETRIA } \\
\text { (\%) }\end{array}$} & \multicolumn{4}{|c|}{$\begin{array}{l}\text { CÁTIONS SOLÚVEIS } \\
\left(\mathrm{cmol}_{\mathrm{c}} \mathrm{kg}^{-1}\right)\end{array}$} & \multirow[b]{2}{*}{$\left(\mathrm{dS} \mathrm{m}^{-1}\right)$} \\
\hline & AREIA & $\overline{\text { SILTE }}$ & ARGLA & $\overline{\mathrm{Ca}}$ & $\mathrm{Mg}$ & $\mathrm{Na}$ & $\bar{K}$ & \\
\hline $0-30$ & 29 & 47 & 24 & 0,08 & 0,08 & 2,34 & 0,04 & 6,95 \\
\hline $30-60$ & 28 & 49 & 23 & 0,11 & 0,12 & 2,41 & 0,05 & 6,77 \\
\hline $60-90$ & 21 & 55 & 24 & 0,06 & 0,06 & 2,08 & 0,05 & 6,00 \\
\hline $90-120$ & 24 & 53 & 23 & 0,08 & 0,08 & 2,62 & 0,06 & 7,42 \\
\hline
\end{tabular}

Tabela 5 - Capacidade de troca de cátions, Porcentagem de Sódio Trocável (PST) e Parâmetros iniciais de Fertilidade do solo aluvial salino-sódico de IpanguassuRN. Médias de 16 determinações.

\begin{tabular}{|c|c|c|c|c|c|c|c|c|c|c|}
\hline \multirow[t]{2}{*}{$\begin{array}{l}\text { PROF. } \\
(\mathrm{cm})\end{array}$} & \multirow{2}{*}{$\begin{array}{c}\mathrm{pH} \\
\text { água } \\
(1: 2,5)\end{array}$} & \multicolumn{5}{|c|}{$\begin{array}{c}\text { CÁTIONS TROCÁVEIS } \\
\left(\mathrm{cmol}_{c} \mathrm{~kg}^{-1}\right)\end{array}$} & & \multirow{2}{*}{$\begin{array}{c}\mathrm{P}^{(1)} \\
\left(\mathrm{mg} \cdot \mathrm{kg}^{-1}\right)\end{array}$} & \multirow{2}{*}{$\begin{array}{l}\text { Mat. Org. } \\
\left({\left.\mathrm{g} . \mathrm{kg}^{-1}\right)}^{-1}\right.\end{array}$} & \multirow{2}{*}{$\begin{array}{l}\text { PST } \\
(\%)\end{array}$} \\
\hline & & $\mathrm{Ca}$ & $\mathrm{Mg}$ & $\mathrm{Na}$ & $\mathrm{K}$ & $\mathrm{H}$ & CTC & & & \\
\hline $0-30$ & 8,6 & 7,71 & 2,85 & 7,00 & 0,26 & 0,11 & 17,93 & 133 & 13,5 & 39,0 \\
\hline $30-60$ & 8,3 & 8,75 & 3,49 & 6,59 & 0,24 & 0,52 & 19,59 & 105 & 6,7 & 33,6 \\
\hline $60-90$ & 8,8 & 7,89 & 2,58 & 7,47 & 0,28 & 0,12 & 18,34 & 140 & 5,7 & 40,7 \\
\hline $90-120$ & 8,7 & 7,46 & 2,62 & 7,29 & 0,24 & 0,18 & 17,79 & 123 & 4,6 & 41,0 \\
\hline
\end{tabular}

(1) Determinado pelo extrator Mehlich-1.

Por ocasião do recebimento da propriedade parte da área estava em pousio ou ocupada por algarobeiras. A situação crítica da área passou a despertar preocupação a partir de meados da década de 1980 quando então por ordem da Diretoria da Empresa foram implantados cerca de 50 ha de milho, abrangendo indistintamente todos os setores da propriedade. A produtividade média foi baixíssima, a produção um 
fracasso e a cultura não conseguiu se estabelecer em trechos do terreno de salinidade/sodicidade mais elevadas.

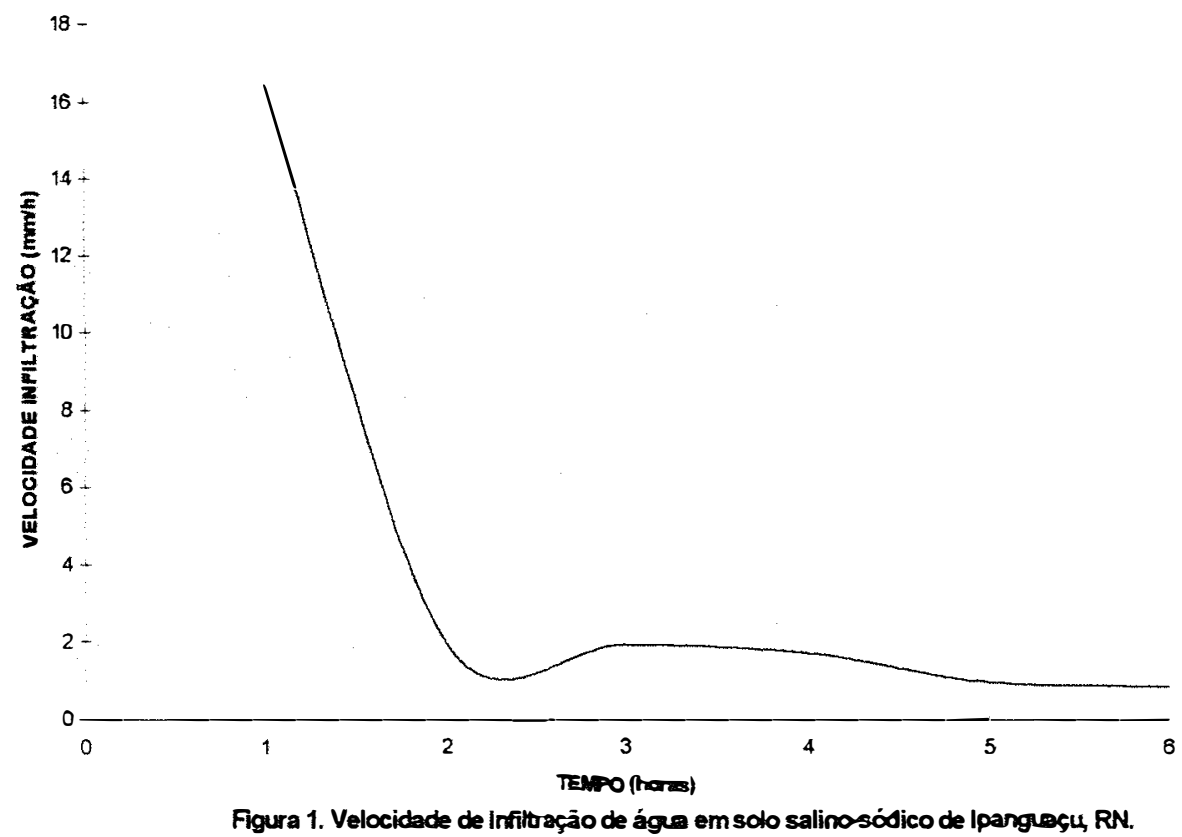

Foi então estabelecido um plano de diagnóstico e caracterização de problemas de sais na área, culminando com a execução de experimentos visando a sua correção. No setor em que os problemas de sais eram bem visíveis, foi feito amostragem

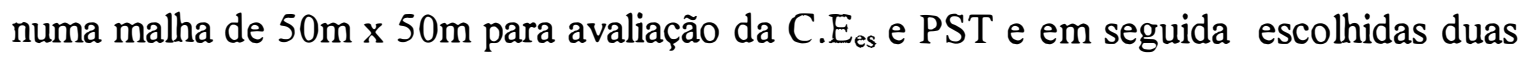
áreas cuja variabilidade da PST não era tão intensa, para condução de experimentos com frações da dose de gesso recomendada e comparação de métodos para correção do solo.

\subsection{Ensaio de doses de gesso}

A necessidade de gesso para redução da porcentagem de sódio trocável (PST) a $15 \%$ na profundidade de $0-40 \mathrm{~cm}$ do solo foi estimada pela expressão apresentada por Pizarro (1985): 


\section{$N G=\underline{(P S T i-P S T f) \times C T C \times 86 \times h \times d s}$}

100

onde,

$\mathrm{NG}=$ Necessidade teórica de gesso $\left(\mathrm{kg} \cdot \mathrm{ha}^{-1}\right)$, baseada no aproveitamento total do cálcio adicionado e considerando que o produto é $100 \%$ puro.

(PSTi - PSTf $)=$ Diferença entre a porcentagem de saturação de sódio inicial e a final desejada.

$\mathrm{CTC}=$ Capacidade de troca de cátions, na camada a ser recuperada $\left(\mathrm{cmol}_{\mathrm{c}} \cdot \mathrm{kg}^{-1}\right)$.

$86=$ Peso equivalente do gesso.

$\mathrm{h}=$ Profundidade (espessura da camada $\mathrm{em} \mathrm{cm}$ ) do solo que se deseja corrigir.

ds = densidade do solo $\left(\mathrm{Mg}_{\mathrm{m}} \mathrm{m}^{-3}\right)$.

Foi instalado um experimento com doses de gesso obedecendo a seguinte metodologia: - A dose prática de gesso, calculada em $25 \%$ acima da necessidade teórica (Pizarro, 1985), foi de aproximadamente $30 \mathrm{Mg} \cdot \mathrm{ha}^{-1}$. Optou-se pelo uso de frações dessa dose correspondendo então aos tratamentos:

0 (testemunha absoluta),

10 Mg.ha ${ }^{-1}$ de gesso

$20 \mathrm{Mg} \mathrm{ha}^{-1}$ de gesso e

$30 \mathrm{Mg} \mathrm{ha}^{-1}$ de gesso.

$\mathrm{O}$ gesso utilizado foi oriundo de mineração do município de Araripina-PE, comercializado com a denominação de "calmina". Segundo Santos (1995), sua composição revela $19 \%$ de sulfato e $12 \%$ de cálcio, solúveis em água.

O experimento foi delineado em blocos ao acaso com 4 tratamentos e 4 repetições, com parcelas de $2.000 \mathrm{~m}^{2}$ e área total do ensaio de $32.000 \mathrm{~m}^{2}$. O gesso foi aplicado à lanço (Novembro/1988) e incorporado com preparo do solo convencional constando de aração mais gradagem. Três meses após foi iniciado o primeiro cultivo, com algodão herbáceo variedade CNPA-precoce 1 , plantado no espaçamento de $1,0 \mathrm{~m} \mathrm{x}$ $0,50 \mathrm{~m}$ com duas plantas por cova e irrigado por aspersão, com turno de rega variando 
em média de 2 a 5 dias e lâmina total de água em torno de $700 \mathrm{~mm}$. O algodão foi adubado conforme recomendação de laboratório de análise de solo da EMPARN que correspondeu a 90-30-00 de N-P-K, tendo como fontes respectivamente o sulfato de amônio, superfosfato triplo e cloreto de potássio. $\mathrm{O}$ nitrogênio foi parcelado em três épocas do ciclo da cultura.

A água usada na irrigação foi captada de poços existentes na propriedade, classificada como de baixa salinidade, média sodicidade e sem problemas de toxicidade de sódio e/ou cloro conforme Pizarro (1985) e Ayers \& Westcot (1991), (Apêndice 7).

$\mathrm{O}$ experimento foi conduzido sob condições naturais de drenagem, e compreendeu amostragens aleatórias de solo com trado de "caneco", fazendo-se 5 perfurações por parcela, para formação de uma amostra composta. As amostras de solo foram coletadas em camadas de $0-30 \mathrm{~cm} ; 30-60 \mathrm{~cm} ; 60-90 \mathrm{~cm}$ e $90-120 \mathrm{~cm}$ nos períodos: inicial (antes da aplicação do gesso) e, aos 6, 12, 30 e 60 meses após a gessagem, com determinações de $\mathrm{pH}$, condutividade elétrica do extrato saturado do solo (C. $\left.\mathrm{E}_{\mathrm{es}}\right)$, cátions extraiveis, solúveis e trocáveis, cloretos, carbonatos e bicarbonatos na solução do solo saturado.

$\mathrm{O}$ pH foi determinado em água $(1: 2,5)$ e os cátions extraiveis em solução $\mathrm{NH}_{4} \mathrm{OAc} 1 \mathrm{~N}$ (Acetato de Amônio pH 7,0). O preparo, extração e determinações de cátions solúveis no extrato saturado do solo foram efetuados conforme metodologia preconizada por Richards (1974). As determinações de sódio e potássio foram feitas em fotômetro de chama e as de cálcio e magnésio em espectrofotômetro de absorção atômica. O hidrogênio foi extraído em acetato de cálcio $1 \mathrm{~N}(\mathrm{pH} 7,0)$ e determinado por titulação com hidróxido de sódio $0,1 \mathrm{~N}$ usando fenolftaleína como indicador. Os valores de cátions trocáveis foram obtidos por diferença entre extraiveis e solúveis. Os cloretos foram determinados por volumetria de precipitação com $\mathrm{AgNO}_{3} 0,05 \mathrm{~N}$ e, carbonatos e bicarbonatos por titulação com solução padrão de $\mathrm{H}_{2} \mathrm{SO}_{4} \quad 0,02 \mathrm{~N}$ e acompanhamento direto em peagâmetro, usando como índices de referência os pHs 8,3 e 4,5 respectivamente. Quando da determinação de sulfatos, foi utilizada a metodologia por turbidimetria apresentada por Vitti (1989). A porcentagem de saturação de sódio trocável no solo (PST) foi obtida através da relação da concentração de sódio trocável 
com a soma das concentrações do total de cátions trocáveis, pelo método usual de cálculo : PST $=100 \mathrm{Na}^{\mathrm{CTC}}{ }^{-1}$.

Os parâmetros básicos empregados na avaliação de melhorias das condições químicas do solo foram a condutividade elétrica do extrato saturado do solo (C.E $E_{\text {es }}$ ), a PST e a concentração de cálcio trocável, representando os dois primeiros os níveis de salinidade e sodicidade, sendo adotados como limites de classes de comparação os valores $4 \mathrm{dS} . \mathrm{m}^{-1}$ el $5 \%$ respectivamente.

O arroz e o algodão foram as culturas escolhidas para o cultivo por serem consideradas como moderadamente tolerante e tolerante a salinidade do solo, suportando, sem redução de rendimento, limites de $C . E_{\text {es }}$ de 3 e 7.7 respectivamente (Rhoades et al., 1992). O arroz em cultivo inundado tolera uma PST de 55\% na camada arável do solo (Abrol \& Bhumbla, 1979) e suporta $30 \mathrm{mmol}_{c} . \mathrm{L}^{-1}$ de cloreto, sem prejuízo na produção (Rhoades et al., 1992).

O primeiro cultivo de algodão foi encerrado em maio de 1989 e, desta data até maio de 1993, a área experimental foi mantida em pousio ou explorada por dois ciclos de algodão que não lograram êxito devido a problemas de condução (irrigação/tratos culturais e fitossanitários). Durante o referido período foram efetuadas as amostragens de solo previstas para avaliação dos parâmetros químicos.

No intervalo de maio a setembro de 1993, sobre a área experimental foi conduzido um ensaio de arroz irrigado em bacias de inundação com área de $200 \mathrm{~m}^{2}$ por parcela dos quais, $180 \mathrm{~m}^{2}$ foram considerados como área útil para colheita. A lâmina de água utilizada foi de $10 \mathrm{~cm}$ com reposição a cada 1-2 dias. $\mathrm{O}$ arroz, variedade Metica -1 , foi instalado por transplantio no espaçamento de $0,30 \mathrm{~m} \times 0,30 \mathrm{~m}$ com população aproximada de 110.000 plantas.ha $^{-1}$; foi adubado apenas com nitrogênio (60 kg.ha ${ }^{-1}$ ) conforme recomendação de laboratório de análise de solo.

Os resultados dos parâmetros de química do solo: condutividade elétrica no extrato saturado $\left(C . E_{\mathrm{es}}\right)$, porcentagem de saturação de sódio trocável (PST) e cálcio trocável $\left(\mathrm{Ca}^{2+}\right)$ foram submetidos a análise de variância, para cada época avaliada, através dos programas estatísticos Sanest e Statgraf-7, em delineamento de blocos ao acaso, com esquema em parcelas subdivididas, com 4 tratamentos (doses de gesso nas parcelas), 4 
profundidades do solo (subparcelas) e 4 repetições. Foi empregado o teste- $\mathrm{F}(\mathrm{P}<0,05)$ para os efeitos de doses de gesso, profundidade do solo e interação entre ambos. Sendo os valores de $\mathrm{F}$ significativos, foram efetuados os contrastes de médias, para as variáveis de interesse, pelo teste de Tukey $(\mathrm{P}<0,05)$. Para cada período de avaliação foi traçado um gráfico, através da planilha eletrônica Excel-5, correspondendo ao comportamento do parâmetro no perfil do solo para cada dose de gesso.

Os resultados de produção de algodão, em rama, e arroz, em casca, também foram submetidos a uma análise de variância e os efeitos das doses de gesso avaliados pelo teste- $\mathrm{F}(\mathrm{P}<0,05)$, com ajuste do modelo em platô - linear response plateau (LRP) descrito por Braga (1983) representando as regressões. Foram confeccionadas figuras relacionando as produções obtidas com as doses de gesso aplicadas, para melhor visualizar o desempenho da variável testada.

\subsection{Ensaio comparativo de métodos de correção do solo}

O experimento consistiu da comparação de práticas mecânicas de preparo do solo associadas ou não ao uso dos condicionadores: químico(gesso) e orgânicos (esterco de curral e palha de carnaúba) para melhorias das condições de salinidade e sodicidade do solo. Os sistemas estudados compreenderam:

- Preparo do Solo:

A - Preparo tradicional do solo (aração + gradagem)

$\mathrm{B}$ - Subsolagem à $50 \mathrm{~cm}$ de profundidade + Preparo tradicional

- Uso de Condicionadores:

1 - Gesso - $30 \mathrm{Mg} \cdot \mathrm{ha}^{-1}$

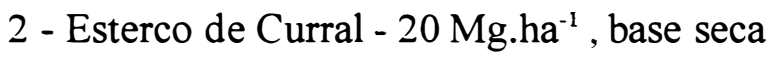

3 - Esterco de Curral (20 Mg.ha-1 $)+$ Gesso (30 Mg.ha $\left.{ }^{-1}\right)$

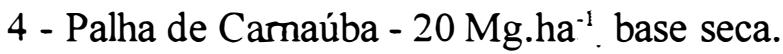

5 - Palha de Carnaúba (20 Mg.ha $\left.{ }^{-1}\right)+$ Gesso (30 Mg.ha- $)$

6 - Testemunha (sem condicionador)

A variável preparo do solo foi avaliada como experimentos em grupo, com dois ensaios instalados lado a lado, separados por uma faixa de $5 \mathrm{~m}$ sem cultura. O 
delineamento dos ensaios foi em blocos ao acaso com 6 tratamentos e 4 repetições. As parcelas foram dimensionadas de $6,0 \mathrm{~m} \times 10,0 \mathrm{~m}$, com $36 \mathrm{~m}^{2}$ de área útil, perfazendo cada ensaio $2.700 \mathrm{~m}^{2}$, incluindo faixas em branco de $5 \mathrm{~m}$ entre os blocos e $3 \mathrm{~m}$ entre as parcelas, para prevenir riscos de interferências entre os métodos testados.

O ensaio com subsolagem teve a operação realizada no início, por ocasião da aplicação dos condicionadores, aos 27 meses e aos 36 meses, a uma profundidade de $50 \mathrm{~cm}$ do solo e com espaçamento de $1 \mathrm{~m}$, realizada através de trator de pneu com subsolador de duas hastes tipo "bico de pato".

Os condicionadores foram aplicados à lanço e incorporados com gradearadora, em abril/1990 e as características químicas do solo acompanhadas por mais de três anos. A dosagem de gesso empregada correspondeu a recomendação integral para redução da PST a $15 \%$ na camada de $0-40 \mathrm{~cm}$ do solo, estimada com base na PST atual e na CTC do solo (Pizarro, 1985), à semelhança do ensaio de doses de gesso.

Os condicionadores orgânicos foram reaplicados após dois anos (junho/1992) e a dose usada (20 Mg.ha- ${ }^{-1}$ em base seca) foi baseada em sugestão de Puttaswamygowda \& Pratt (1973). A composição química dos materiais utilizados está apresentada na Tabela 6.

Tabela 6 - Composição química dos condicionadores orgânicos.

\begin{tabular}{|c|c|c|c|c|c|c|c|c|c|}
\hline \multirow[b]{2}{*}{ Condicionador } & \multicolumn{9}{|c|}{ NUTRIENTES TOTAIS (base seca) } \\
\hline & $\mathrm{N}$ & $\mathrm{P}$ & $\mathrm{K}$ & $\mathrm{Ca}$ & $\mathrm{Mg}$ & $\mathrm{Na}$ & $\mathrm{Zn}$ & $\mathrm{Cu}$ & $\mathrm{Mn}$ \\
\hline & \multicolumn{6}{|c|}{ 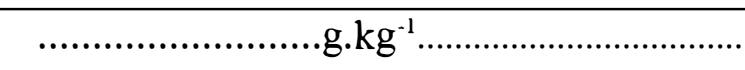 } & \multicolumn{3}{|c|}{..........mg.kg ${ }^{-1} \ldots \ldots \ldots . . .}$. \\
\hline Palha Carnaúba & 20,2 & 1,4 & 10,1 & 2,1 & 2,5 & 0,9 & 21 & 7 & 133 \\
\hline Esterco curral & 10,2 & 4,2 & 17,5 & 9,8 & 6,5 & 4,0 & 68 & 19 & 238 \\
\hline
\end{tabular}

Para avaliação da variação de sais no perfil do solo, foram feitas amostragens em cada unidade experimental, em camadas de 0-15 cm; 15-30 cm; 30-45 $\mathrm{cm} ; 45-60 \mathrm{~cm}$ e $60-90 \mathrm{~cm}$. As coletas de amostra de solos foram feitas no início (antes da aplicação dos condicionadores) e decorridos 9, 24 e 40 meses da aplicação. 
Para coleta das amostras e determinação dos parâmetros básicos de avaliação: C.E $E_{\mathrm{es}}$, PST e cálcio trocável, no perfil do solo, foram seguidos os mesmos procedimentos adotados para o ensaio de fracionamento de gesso.

Com a finalidade de determinar o efeito dos métodos de recuperação sobre a produção de culturas, a área experimental foi explorada com dois ciclos de arroz (variedade Metica - 1), nos períodos de maio a setembro de 1990 e de abril a agosto de 1993 e, com dois ciclos de algodão: junho a outubro/1991 e julho a novembro/1992, permanecendo em pousio nos demais intervalos de tempo. Na condução das culturas foram adotados os mesmos procedimentos empregados no ensaio de fracionamento de gesso. O último cultivo de arroz foi irrigado por bacias de inundação enquanto nos demais cultivos o sistema empregado foi por aspersão.

Os valores obtidos de condutividade elétrica no extrato saturado do solo (C.E $\mathrm{E}_{\text {es }}$ ), de porcentagem de saturação de sódio trocável (PST) e de cálcio trocável, para cada época de avaliação no solo, foram submetidos a análise de variância com ensaios agrupados dois a dois, delineados em blocos ao acaso com 4 repetições, em esquema de parcelas subdivididas com os 6 tratamentos (condicionadores) constituindo as parcelas e as 5 profundidades amostradas as sub-parcelas. Os testes estatísticos, niveis de significância e programas de computador utilizados foram os mesmos empregados no ensaio de fracionamento do gesso. Para as determinações no solo também foram confeccionadas figuras para melhor observar o comportamento dos parâmetros em camadas do perfil, ao longo do tempo, sob efeito dos tratamentos.

Com os resultados das análises químicas de solo realizadas aos 24 meses após a aplicação dos condicionadores, foram preparadas tabelas para averiguar o efeito dos métodos de correção do solo na composição de bases trocáveis do complexo sortivo e no pH. Com as determinações na solução do solo aos 40 meses foram feitos balanços iônicos e estimativas das relações de adsorção de sódio (RAS), conforme Richards (1974), para todas as situações pesquisadas.

Os resultados de produção de arroz em casca e de algodão em rama, foram submetidos a análises de variância com teste $F(P<0,05)$ e contraste de médias pelo teste de Tukey ao mesmo nível de probabilidade. 
Um resumo sintético da condução dos ensaios é apresentado no cronograma de execução da Tabela 7.

Tabela 7 - Cronograma de execução dos ensaios em campo.

\begin{tabular}{|c|c|c|c|c|c|}
\hline \multirow{2}{*}{$\begin{array}{l}\text { ATIVIDADES/ENSAIO } \\
\text { ENSAIO DOSES GESSO }\end{array}$} & & \multicolumn{4}{|c|}{ MÊS/ANO DE EXECUÇÃO } \\
\hline & & \multirow{3}{*}{\multicolumn{2}{|c|}{$11 / 89$}} & \multirow[b]{3}{*}{$06 / 91$} & \multirow{5}{*}{$12 / 93$} \\
\hline Aplicação gesso & $11 / 88$ & & & & \\
\hline Amostragem solo & $11 / 88$ & & & & \\
\hline Condução Algodão & \multicolumn{4}{|c|}{ 02/89 A 05/89 (Irrigado por aspersão) } & \\
\hline Condução arroz & \multicolumn{4}{|c|}{ 05/93 A 09/93 (Irrigado por inundação) } & \\
\hline \multicolumn{6}{|c|}{ ENSAIO MÉTODOS CORREÇÃO } \\
\hline \multicolumn{2}{|l|}{ Instalação } & & & & \\
\hline Amostragem solo & $04 / 90$ & $12 / 90$ & & $05 / 92$ & $10 / 93$ \\
\hline \multicolumn{2}{|c|}{ Reaplic. cond. orgânicos } & \multicolumn{4}{|c|}{$06 / 92$} \\
\hline Subsolagem & \multicolumn{2}{|l|}{$04 / 90$} & $07 / 92$ & \multicolumn{2}{|c|}{$04 / 93$} \\
\hline Condução arroz & \multicolumn{2}{|c|}{ 05/90 A 09/90 (Aspersão) } & \multicolumn{3}{|c|}{ 04/93 A 08/93 (Inundação) } \\
\hline Condução algodão & 06/91 A 10/91 & E & \multicolumn{3}{|c|}{ 07/92 A 11/92 (Aspersão) } \\
\hline
\end{tabular}

Durante o período experimental (1989 a 1993) transcorreram pluviosidades anuais consideradas boas, da ordem de $858 \mathrm{~mm}$; regulares, próximos de $550 \mathrm{~mm}$; ruim, em torno de $280 \mathrm{~mm}$ e péssima, próxima de $150 \mathrm{~mm}$, caracterizando o ano como extremamente seco (Apêndice 8). Em todo o período não foi registrado inundação da área em decorrência de transbordamento dos Rios Pataxós e/ou Açu. 


\section{RESULTADOS E DISCUSSÃO}

O comportamento dos parâmetros avaliados no perfil do solo pode ser visualizado nas figuras 2 a 7 e os resultados médios, acompanhados dos respectivos resumos dos testes estatísticos estão contidos nos apêndices 1 a 6 . Os resultados de produção são apresentados na Figura 8 e Tabela 12.

\subsection{Salinidade do solo}

\subsubsection{Efeito dos condicionadores}

Das características de solos afetados por sais a salinidade é a mais sensível às variações do meio. Na Figura 2.a, embora os valores de C.E $E_{\text {es }}$ tenham variado no intervalo de 2,21 a 5,83 dS.m ${ }^{-1}$, sendo mais proeminente no perfil do solo a curva dos resultados sem gesso, as médias não diferem entre si $(\mathrm{P}<0,05$; Apêndice 1).

Aos 60 meses após a gessagem ficou bem nítido o comportamento da C.E $E_{\mathrm{cs}}$ no perfil do solo para as diversas frações da necessidade de gesso (Figura 2.b). O gesso exerceu um efeito diferenciado na salinidade, em profundidades do solo, de 60 - 90 e $90-120 \mathrm{~cm}$ com médias de C. $E_{\text {es }}$ estatisticamente inferiores $(P<0,05)$ para todos as doses, em relação a testemunha. Na última profundidade a C.E $E_{\text {es }}$ média obtida com 20

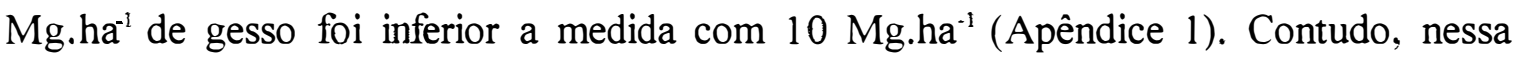
época, em nenhum dos tratamentos com gesso foi atingido valores acima da salinidade crítica ou limiar, para o arroz, em profundidades de até $60 \mathrm{~cm}$, condição que favorece as menores doses de gesso.

No ensaio de métodos de correção, nas determinações aos 9 meses da aplicação dos condicionadores os tratamentos contendo gesso apresentaram na profundidade de $0-15 \mathrm{~cm}$ valores de C. $E_{\text {es }}$ estatisticamente iguais entre si e superiores aos demais (Apêndice 2). A maiores profundidades todos apresentaram comportamento 
semelhante (Figura 3.a). Na Figura 3.b, o entrelaçamento das curvas dificulta a interpretação do efeito dos condicionadores na salinidade entretanto, os tratamentos com gesso favoreceram para maiores valores na camada superficial do solo, não exerceram influência nas duas intermediárias e contribuíram para menores valores de C.E $\mathrm{E}_{\mathrm{es}}(\mathrm{P}<$ $0,05)$, principalmente quando associado a condicionadores orgânicos, nas duas maiores profundidades (Apêndice 2).
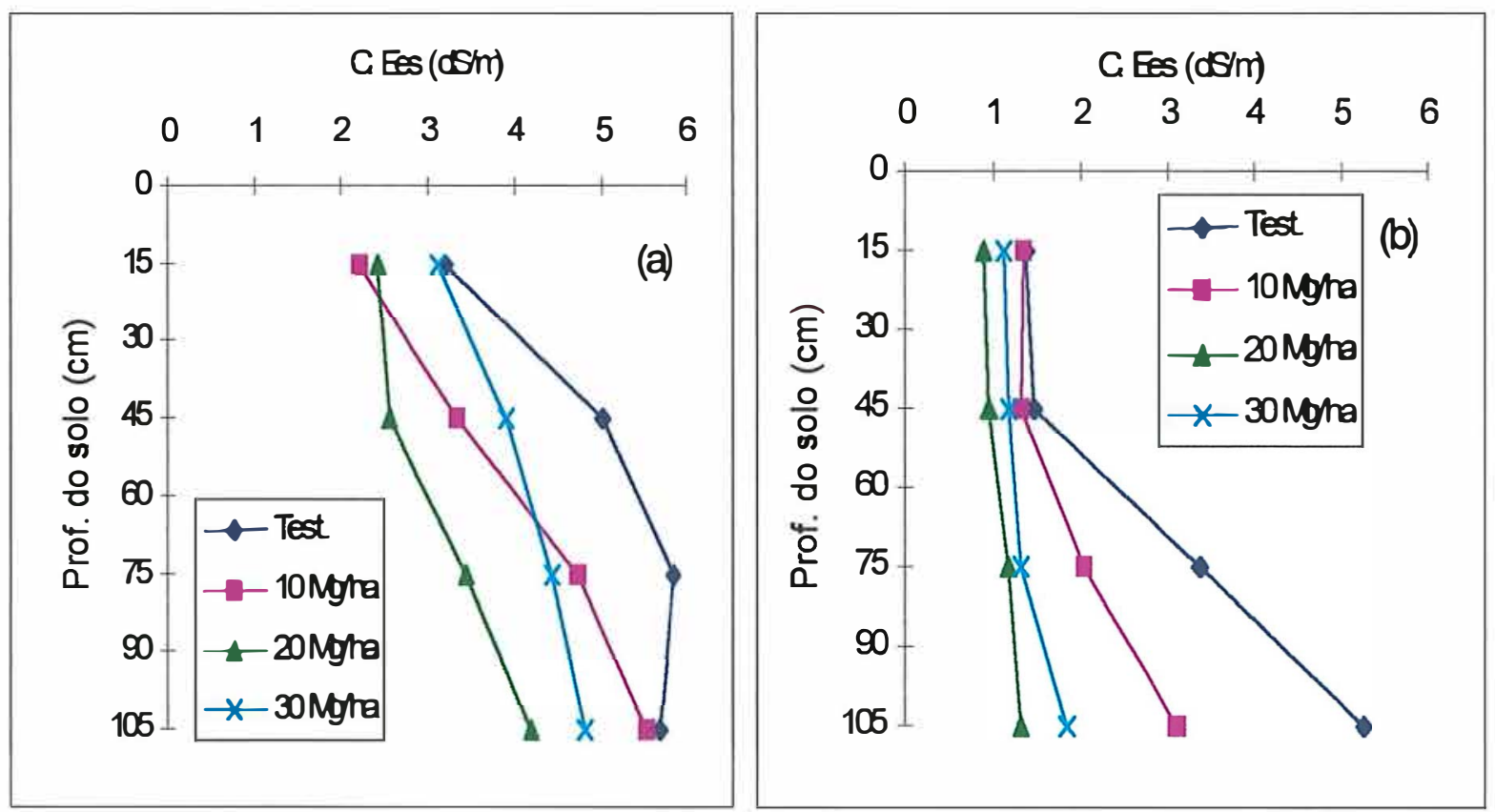

Figura 2 - Condutividade elétrica em extratos saturados (C. Ees) de profundidades do solo, em duas épocas após a aplicação de $0,10,20$ e $30 \mathrm{Mg} \cdot \mathrm{ha}^{-1}$ de gesso: 30 meses (a) e 60 meses (b).

$\mathrm{Na}$ avaliação aos 24 meses, embora o teste - $\mathrm{F}$ tenha sido significativo (Apêndice 2), não foram constatadas diferenças entre os valores médios de C.E $E_{\text {es }}$ dos tratamentos, pelo Tukey $(\mathrm{P}<0,05)$. Na Figura $3 \mathrm{c}$, o comportamento das curvas referentes a efeito dos condicionadores é bem semelhante, com valores de C. $\mathrm{E}_{\text {es }}$ oscilando em torno de $4 \mathrm{dS} / \mathrm{m}$ ao longo do perfil.

As Figuras 3d e 3e chamam a atenção pelo efeito da palha de carnaúba na C.E $E_{\text {es }}$; na primeira, a partir da profundidade de $45-60 \mathrm{~cm}$ do solo sobressai-se os maiores valores, superiores aos obtidos com a combinação gesso mais esterco $(P<0,05$; 
Apêndice 2) e acima da salinidade limiar para o arroz. $\mathrm{Na}$ segunda, a curva que representa os efeitos da palha de carnaúba destaca-se das demais e acentua-se a salinidade nas ultimas profundidades do solo onde também a C. $E_{\text {es }}$ é maior do que a obtida com gesso mais esterco.

Verifica-se que os tratamentos com gesso apresentaram aos 9 meses, na camada superior do solo $(0-15 \mathrm{~cm})$, valor médio de C.E $\mathrm{E}_{\mathrm{es}} 2,2 \mathrm{dS} . \mathrm{m}^{-1}$ maior, em relação aos tratamentos que não receberam esse condicionador (Figuras $3 a$ e $3 b$ ). Esse fato ocorreu em conseqüência da dissolução do gesso, uma vez que as lâminas de água aplicadas até então não foram suficientes para promover a lixiviação dos sais. Neste sentido, concordam os trabalhos de Gupta \& Bajpai (1977) e Santos (1995). Por outro lado, no decorrer do tempo o efeito do gesso acarretou uma diminuição da salinidade mesmo em camadas mais profundas do solo (figura $2 \mathrm{~b}$ ), resultados que se assemelham aos obtidos por Gupta \& Bajpai (1977), Lucena (1986) e Gheyi et al. (1995) sendo explicados pelo efeito amenizador do gesso na impermeabilização do solo (Frenkel \& Hadas, 1981) favorecendo a infiltração de água no solo e aumento da condutividade hidráulica (Abrol et al, 1975; McIntire, 1979; Shainberg \& Letey, 1984; Freitas et al., 1984 e Ilyas et al., 1993). O aumento da salinidade do solo pelo uso do gesso é portanto temporário e depende da disponibilidade e fluxo de água (Gupta \& Bajpai, 1977), pressupondo-se que seria atingido tal comportamento com maior duração da pesquisa de Santos (1995).

Embora o esterco de curral também seja fonte de eletrólitos, proporcionou melhorias na salinidade em profundidades do solo, se constituindo no resíduo orgânico mais benéfico conforme Puttaswamygowda \& Pratt (1973), com efeito mais pronunciado quando associado a gesso (Figura 3). O efeito salinizante do esterco de curral é de curta duração pois, os eletrólitos se constituem principalmente de sais de potássio oriundos de tecidos vegetais, consumidos como forragem, bastando água para liberação de $2 / 3$ de seu conteúdo, sem necessidade de atuação de microorganismos (Freire, 1975). Neste caso, como as avaliações foram 9 e 16 meses após as aplicações, seu efeito já havia se diluído. 

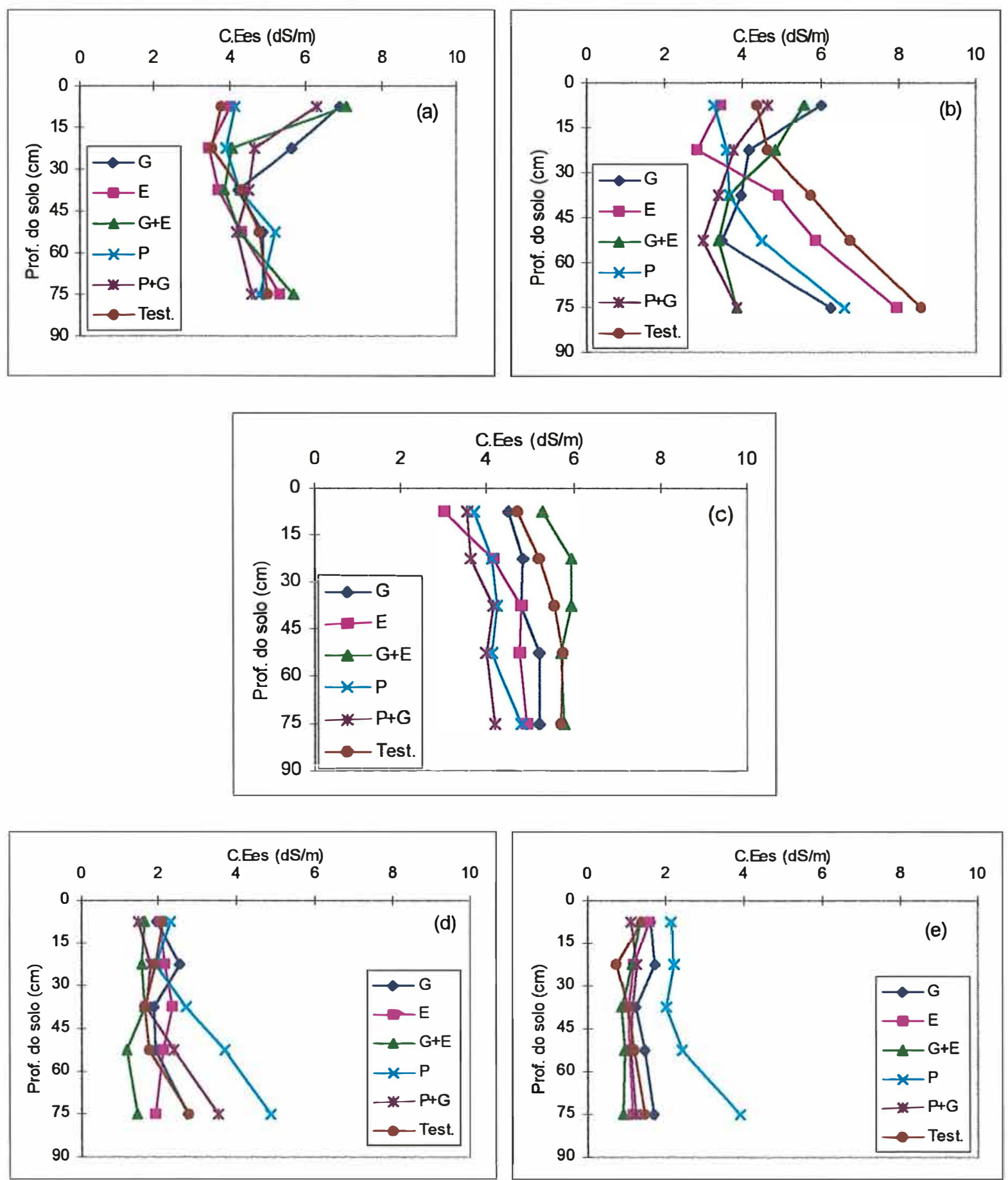

$(\mathrm{G})=$ gesso; $(\mathrm{E})=$ esterco; $(\mathrm{P})=$ palha de carnaúba; $($ Test $)=$ testemunha

Figura 3 - Condutividade elétrica em extratos saturados (C. Ees) de profundidades do solo, em três épocas após a aplicação dos condicionadores e sob duas condições de preparo do solo: Sem subsolagem, após nove meses (a), após 24 meses(c) e após 40 meses (d); com subsolagem, após 9 meses (b) e após 40 meses (e). 
Efeito danoso à salinidade do solo foi provocado pela incorporação de palha de carnaúba. Após quase um ano e meio da reaplicação sua ação ainda se manifestava (Figuras 3d e 3e). O problema pode se encaixar na advertência de Kovda \& Minashina ${ }^{1}$, citados por Szabolcs (1989) de que os resíduos de plantas desenvolvidas em halobiomas podem ser fonte de sais, agravante da salinidade do solo. Num raciocínio paralelo, o efeito da palha de carnaúba exerceu pequena contribuição para o movimento de água no solo (Freitas et al., 1984) e, considerando que para se atingir melhorias nas suas condições físicas seriam necessárias elevadas quantidades de resíduo orgânico, além do aumento de salinidade podem ocorrer desequilíbrios nutricionais (Ayers \& Westcot, 1991).

\subsubsection{Efeito do preparo de solo}

As Figuras 3a e 3d representam as condições usuais de preparo do solo (aração seguida de gradagem) e as $3 b$ e $3 e$ as mesmas operações acrescidas de prévia subsolagem. As figuras seguidas das letras a e b correspondem ao tempo de 9 meses após a aplicação dos condicionadores enquanto as seguidas de $\mathrm{d}$ e e, há 40 meses do início do experimento e 4 meses da última subsolagem. Aos 24 meses, como a subsolagem deixou de ser realizada, nenhum efeito da variável e/ou suas interações na salinidade do solo foi constatado $(\mathrm{P}<0,05$; Apêndice 2) representando a Figura $3 \mathrm{c}$ a média das duas situações para o comportamento da salinidade, sob efeito apenas dos condicionadores.

Não foi constatado efeito isolado da subsolagem após 9 meses da realização entretanto, sua interação com condicionadores ou profundidades do solo foi significativa (Apêndice 2) indicando que seu efeito variou com a mudança de fator ou nível das outras variáveis. Em números absolutos os maiores valores de C.Ees $\left(6 \mathrm{dS} . \mathrm{m}^{-1}\right)$ foram detectados nas combinações subsolagem $x$ testemunha e $\left(6,16 \mathrm{dS} \cdot \mathrm{m}^{-1}\right)$ para subsolagem $\times$ profundidade de $60-90 \mathrm{~cm}$; os menores valores absolutos também foram verificados na área subsolada: 3,71 e 3,96 dS.m. ${ }^{-1}$ respectivamente para gesso mais palha $\mathrm{e}$ $15-30 \mathrm{~cm}$ de profundidade. Convém lembrar que todos esses valores situam-se acima da

${ }^{1}$ KOVDA, V.A.: MINASHINA, N.G., op. cit., p.18 
salinidade limiar para o arroz $\left(3 \mathrm{dS} \cdot \mathrm{m}^{-1}\right)$ e os maiores, próximo do limite para o algodão $\left(7,7 \mathrm{dS} \cdot \mathrm{m}^{-1}\right)$.

Comparando as figuras $3 \mathrm{~d}$ e $3 \mathrm{e}$ observa-se que na última, representando a salinidade em área subsolada, o efeito dos tratamentos proporcionou um comportamento da C. $E_{\text {es }}$ bem mais uniforme em todo o perfil, à exceção da palha de carnaúba, que mesmo na condição pós-inundada apresentou valores de $C . E_{\text {es }}$ maior que $2 \mathrm{dS} . \mathrm{m}^{-1}$. A área subsolada, na determinação aos 40 meses, apresentou um valor médio de $C . E_{\text {es }}$ no perfil do solo inferior ao da não subsolada ( $\mathrm{P}<0,01$; Apêndice 2$)$. $\mathrm{O}$ comportamento da salinidade sob efeito da incorporação de palha de camaúba ocasionou a significância da interação condicionador x profundidade, apresentando o maior valor absoluto de C.E $E_{\text {es }}$ $\left(3,87 \mathrm{dS} \cdot \mathrm{m}^{-1}\right)$ a $60-90 \mathrm{~cm}$ de profundidade e o menor, proporcionado pela testemunha de $0,74 \mathrm{dS} \cdot \mathrm{m}^{-1}$ a $15-30 \mathrm{~cm}$. A interação subsolagem $\times$ profundidade também foi significativa entretanto, como todos os valores médios de C.E $E_{\text {es }}$ no perfil do solo da área subsolada foram inferiores a $2 \mathrm{dS} \cdot \mathrm{m}^{-1}$ não há por que se preocupar, não valendo a pena discuti-los.

Os valores médios para salinidade nas figuras $3 \mathrm{~d}$ e $3 \mathrm{e}$ correspondem a menos da metade dos registrados na média das figuras $3 a, 3 b$ e $3 c$ e justifica-se pela disponibilidade de água na área, proveniente do sistema de irrigação utilizado. Enquanto nas duas primeiras épocas a irrigação foi por aspersão, na última foi por inundação, com lâmina contínua de água diluindo os eletrólitos em solução e possibilitando a descida de sais no perfil do solo. Tal comportamento não se registrou nos períodos anteriores devido a dotação de água, oriunda tanto da pluviosidade (Apêndice 8) como da irrigação por aspersão, serem temporárias e insuficientes para a lixiviação de sais.

$\mathrm{O}$ efeito da subsolagem diminuiu acentuadamente a salinidade do solo à semelhança das pesquisas de Rasmussen et al. (1972) e Silva (1978), com indícios de melhores resultados quando associada a condicionadores químico ou químico mais orgânico conforme observações de El Mowelhi et al. ${ }^{2}$, citados por Pereira et al. (1985), principalmente em condições mais limitantes de água.

A subsolagem é eficiente na redução da salinidade no perfil do solo, por facilitar a infiltração de água porém, o seu efeito foi temporário concordando com

${ }^{2}$ EL MOWELHI et al., op. cit., p.12 
afirmação de Ayers \& Westcot (1991) e muito menos duradouro do que o previsto por Gheyi \& Medeiros (1991). Em termos de redução da salinidade os resultados obtidos nesta pesquisa apontam para a necessidade de realização da subsolagem precedendo cada cultivo irrigado por aspersão. Mesmo com vantagens, o emprego da subsolagem também está condicionado as exigências da cultura explorada; no caso do arroz que é moderadamente tolerante a salinidade, valores de C.E $E_{\text {es }}$ menores que $3 \mathrm{dS} . \mathrm{m}^{-1}$ não acarretam prejuizo na produtividade (Rhoades et al, 1992) e, se no solo não subsolado os valores estão aquém desse limite, com a segurança de que o manejo da irrigação o manterá, não se justifica a operação de subsolagem.

\subsection{Porcentagem de sódio trocável (PST)}

\subsubsection{Efeito dos condicionadores}

Analisando as Figuras 4 e 5 observa-se que os valores de PST aumentam com a profundidade do solo, tendendo a estabilizar após $60 \mathrm{~cm}$, em valores próximos de $70 \%$.

O comportamento da PST sob efeito das doses de gesso em períodos de até 5 anos após a gessagem está expresso nas figuras 4 a e 4 d. As figuras 5 a a $5 f$ exprimem a PST no perfil do solo possibilitando a comparação do efeito do gesso com condicionadores orgânicos e suas combinações.

No resumo das análises estatísticas do ensaio de doses de gesso (Apêndice 3) observa-se que não foi constatado efeito significativo do condicionador na PST do solo, em nenhuma das épocas avaliadas $(\mathrm{P}<0,05)$. A menor probabilidade para ocorrer diferenças nas médias de PST foi da ordem de $30 \%$ para a interação gesso $\mathrm{x}$ profundidade aos 30 meses da aplicação. É bem provável que os resultados obtidos tenham sido influenciados pela alta variabilidade natural do solo, que os elevados valores da PST em profundidade mascarem os menores em superficie e que as macroparcelas de até $2.000 \mathrm{~m}^{2}$ tenham contribuído para o fato, ocasionando altos coeficientes de variações nas análises.

Recorrendo a uma interpretação gráfica das figuras 4 a a $4 \mathrm{~d}$ para auxiliar na avaliação dos resultados de PST verifica-se que, em valores médios, as curvas 
correspondentes as doses de gesso se destacam da testemunha. $\mathrm{Na}$ figura $4 \mathrm{a}$, embora os valores estejam influenciados pelos cátions solúveis, o que é relevante para o sódio, se manifesta o mesmo direcionamento visualizado no perfil do solo para as demais figuras 4 .
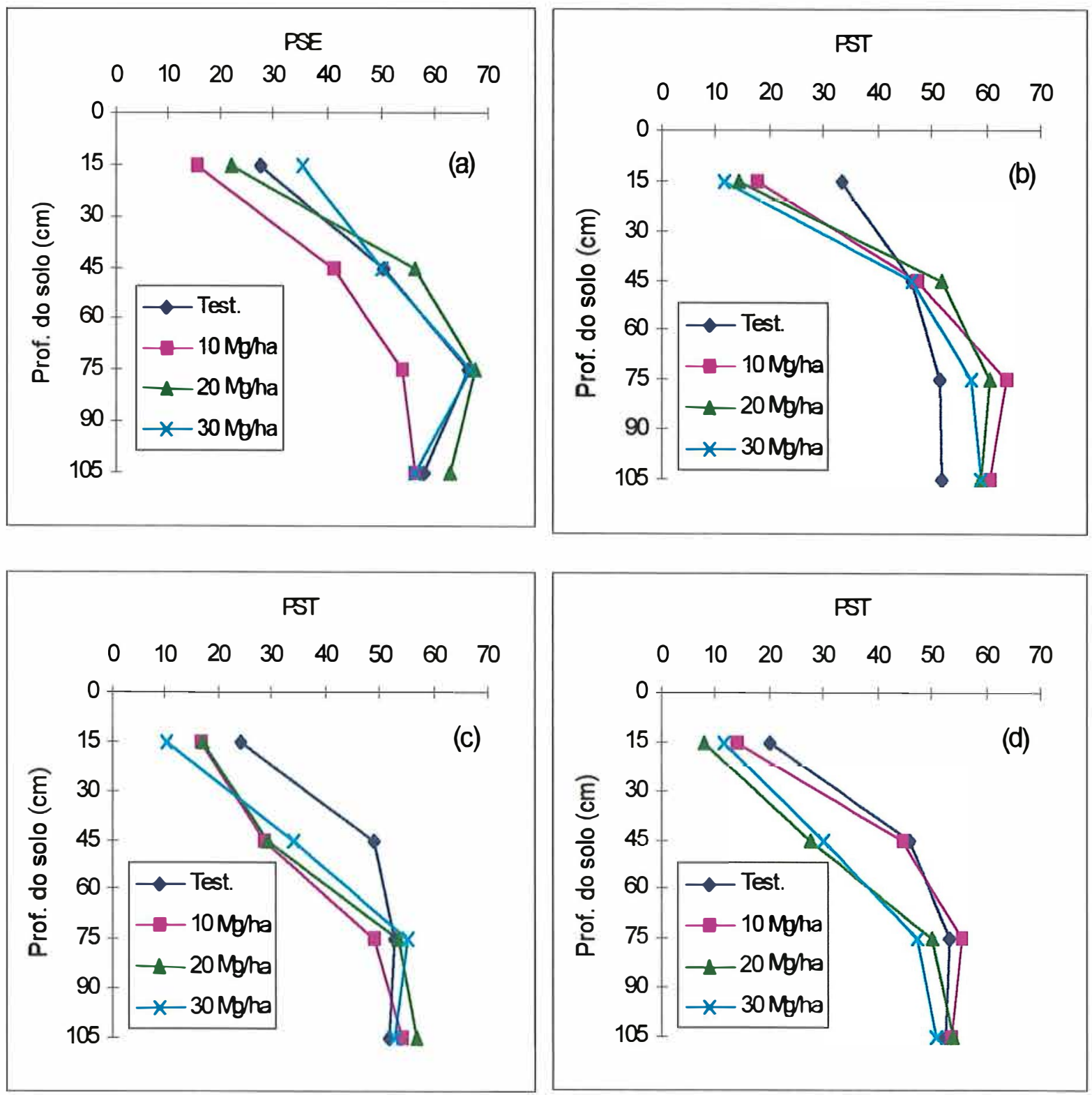

Figura 4 - Porcentagem de sódio trocável (PST) em profundidade do solo, para as doses de $0,10,20$ e $30 \mathrm{Mg} \cdot \mathrm{ha}^{-1}$ de gesso, em 4 épocas após a aplicação: porcentagem de sódio extraível (PSE) aos 6 meses (a), PST aos 12 meses (b), PST aos 30 meses(c) e PST aos 60 meses (d). 
Existe um comportamento bem evidenciado para menores valores de PST na camada de 0-30 cm de solo nos tratamentos com gesso, após 12 meses da aplicação (Figura 4b), estendendo-se os indícios de efeito até 30-60cm, após 30 e 60 meses (Figuras $4 \mathrm{c}$ e $4 \mathrm{~d}$ ).

Até 30 meses da gessagem as curvas de PST nos tratamentos com o condicionador seguem juntas no perfil do solo enquanto, aos 60 meses as que correspondem as maiores doses se separam da menor. No período 12 a 60 meses de avaliação, na profundidade de $0-30 \mathrm{~cm}$, a PST variou de 20 a $33,4 \%$ na testemunha, 13,8 a $17,5 \%$ na dose de $10 \mathrm{Mg} \cdot \mathrm{ha}^{-1}$ de gesso, de 8 a $17 \%$ com $20 \mathrm{Mg}^{-h^{-1}}$ e de 10 a $11,7 \%$ para $30 \mathrm{Mg} \cdot \mathrm{ha}^{-1}$ de gesso. Em todos os intervalos de PST registrados não há risco de redução no rendimento de arroz irrigado por inundação, em decorrência de sodicidade elevada (Abrol \& Bhumbla, 1979).

Nas figuras 5a a 5f, representando resultados de métodos de correção de solo, ficou bem explicitado e com fundamento estatístico o efeito dos condicionadores na redução ou aumento da PST. Na profundidade de $0-15 \mathrm{~cm}$, em área não subsolada, aos 9 meses após a aplicação dos condicionadores, observa-se o início de dois agrupamentos de retas (Figura 5a). O primeiro, com média de PST oscilando em torno de $12 \%$, corresponde aos tratamentos que contém gesso enquanto o segundo, com média de PST situada ao redor de $32 \%$ corresponde aos tratamentos testemunha e condicionadores orgânicos sozinhos. O efeito do gesso isolado provocou redução na PST para 14,3\%, valor inferior ao registrado na testemunha $(P<0,05$; Apêndice 4). Ao associar-se gesso ao esterco de curral o efeito foi benéfico e mais pronunciado, atingindo uma PST média de $10,4 \%$, menor do que as obtidas na testemunha e esterco isolado $(P<0,05)$. Em camadas mais profundas do solo, os condicionadores não surtiram efeito até essa época.

Em condições de subsolagem o comportamento dos condicionadores foi diferente do anterior, com o efeito do esterco de curral sendo mais favorável em profundidades abaixo de $30 \mathrm{~cm}$, oscilando a PST entre 27 e $33 \%$, sendo estes valores menores do que os determinados na testemunha ( $\mathrm{P}<0,05$; Apêndice 4, Figura $5 \mathrm{~b})$. Na figura 5c, referente a PST após 24 meses da aplicação dos condicionadores na área não subsolada, visualiza-se uma ampliação dos dois feixes de curvas que se distinguem bem até a profundidade de $30-45 \mathrm{~cm}$. Nas duas primeiras camadas a PST medida sob efeito do 

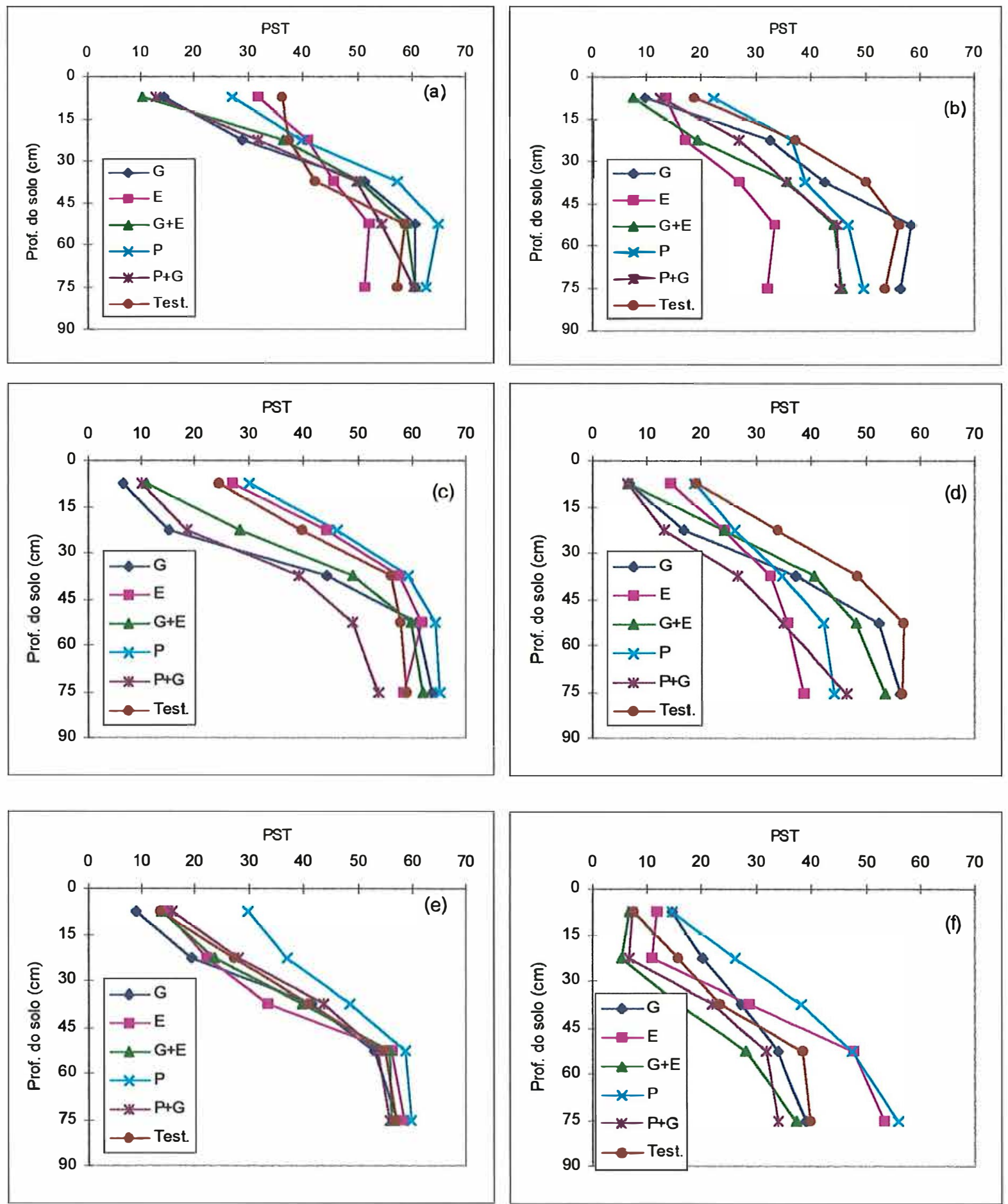

$(\mathrm{G})=$ gesso; $(\mathrm{E})=$ esterco; $(\mathrm{P})=$ palha de carnaúba; $($ Test $)=$ testemunha

Figura 5 - Porcentagem de sódio trocável (PST) em profundidade do solo, em rês épocas após a aplicação dos condicionadores e sob duas condições de preparo do solo: Sem subsolagem após nove meses (a), após 24 meses (c) e após 40 meses (e);com subsolagem após 9 meses (b), após 24 meses (d) e após 40 meses (f). 
gesso sozinho, foi inferior a medida sob efeito da palha de carnaúba sozinha e, na de 30 45 a medida na combinação gesso + palha foi inferior a da palha sozinha $(P<0,05$; Apêndice 4). A PST média em profundidades de até $45 \mathrm{~cm}$, no feixe de curvas com gesso situou-se entre 9 e $44 \%$, no outro feixe, nas curvas que representam só condicionadores orgânicos ficou entre 28 e $58 \%$ e na testemunha entre 24 e $56 \%$. Na área subsolada (Figura 5d) embora os tratamentos com gesso tenham apresentado PST próxima de 6\%, a testemunha $19 \%$ e os condicionadores orgânicos sozinhos 14 e $18,7 \%$, não foi constatado diferenças entre médias de tratamentos pelo teste de Tukey $(\mathrm{P}<0,05)$.

Aos 40 meses do início do experimento o efeito dos condicionadores na redução da PST parece ter cessado (Apêndice 4) não havendo significância estatística pelo teste - F $(P<0,05)$ nem para as interações dessa variável. As curvas de PST formam um único feixe, exceto para a palha de camaúba que se destaca nos dois perfis de solo (Figuras 5 e e $5 \mathrm{f}$ ) com elevada sodicidade, sendo acompanhada pela do esterco de curral sozinho a partir de $30-45 \mathrm{~cm}$ de profundidade, na área subsolada (Figura $5 \mathrm{f}$ ).

A redução da PST no solo com a prática da gessagem combina com os resultados de Abrol \& Bhumbla (1979), Cavalcante (1984), Ferreyrah \& Coelho (1986), Singh et al., (1989), Armstrong \& Tanton (1992) e Santos (1995). Entretanto, a estimativa da quantidade de gesso para correção do sódio a uma PST desejada, como se baseia em modelos teóricos, não leva em conta fatores de campo como práticas de cultivo que podem contribuir para amenizar a sodicidade. Esta preocupação é compartilhada por diversos autores (Shainberg \& Letey, 1984; Oliveira, 1988 e Sumner, 1993). No rol dos cátions trocáveis, pela sua valência e raio iônico hidratado, o sódio situa-se no último lugar quanto a seletividade de adsorção, série liotrófica, o que em si, é um fator favorável para sua substituição pois. em condições de igualdade de concentração é adsorvido na sobra de cargas após o preenchimento por $\mathrm{H}^{0}>>>\mathrm{Al}^{3+}>\mathrm{Ca}^{2+}>\mathrm{Mg}^{2+}>\mathrm{K}^{+}>\mathrm{NH}_{4}{ }^{+}>\mathrm{Na}^{+}$. O hidrogênio é uma exceção, tem menor massa atômica mas alta energia de adsorção, da ordem de 4 vezes a do cálcio e 17 vezes a do sódio (Yagodin, 1984), podendo substituir os demais cátions no complexo de troca. Dessa forma, os resultados experimentais obtidos neste trabalho, evidenciam reduções na PST com $30 \%$ da necessidade estimada de gesso, tão favoráveis quanto a recomendação 
integral. Nesse caso, contam mais dois fatores, a solubilidade do gesso que é baixa ( 2 g.L $\mathrm{L}^{-1}$ ) e a possível precipitação de parte do cálcio em reação com carbonato $\mathrm{e}$ bicarbonato possivelmente, mais acentuada para maiores doses de gesso.

A importância do gesso quando incorporado ao solo tal como foi exposto no item de salinidade, se reflete num aumento de umidade com concomitante melhoria na infiltração acumulada e condutividade hidráulica no perfil do solo (Abrol et al., 1975; Mc Intyre, 1979; Freitas et al., 1984; Singh et al, 1989 e Ilyas et al., 1993), dando oportunidade de acesso do cálcio aos sítios de adsorção ocupados por sódio, para reações de troca. $\mathrm{O}$ gesso como fonte de eletrólitos para a solução do solo, desempenha o papel de repressor da dupla camada difusa das argilas, impede a sua expansão e em conseqüência ameniza a dispersão de partículas, favorecendo o movimento de água.

Por outro lado, o formato das figuras 4 e 5 evidencia a existência de camadas de muito baixa permeabilidade em profundidades a partir de $60 \mathrm{~cm}$ e, nessa condição, conforme enfatiza Ilyas et al. (1993) o fluxo de água é limitado a remoção do sódio é dificultada e não se consegue a correção do solo.

Os condicionadores orgânicos em algumas circunstâncias contribuíram para a redução da PST concordando com resultados de Puttaswamygowda \& Pratt (1973), Singh \& Singh (1989) e Almeida (1984). Porém, após a reaplicação aos 24 meses do início do experimento, passando a um aporte total na área de $40 \mathrm{Mg} \cdot \mathrm{ha}^{-1} \mathrm{em}$ peso seco o efeito de incorporação da palha de carnaúba foi danoso para a PST do solo, com manutenção de valores elevados em todo o perfil. $O$ fato pode estar relacionado a adaptação da carnaubeira à condição de solo afetado por sais e que poderia se constituir em fonte biológica do problema (Kovda \& Minashina ${ }^{3}$ citados por Szabolcs, 1989). Esta alternativa não tem respaldo na composição química da palha de carnaúba (Tabela 6) e, outra hipótese, é que a palha sendo de lenta decomposição microbiana provoca uma maior retenção de água na camada de solo incorporada, com acentuada redução na lixiviação dos sais.

\footnotetext{
${ }^{3}$ KOVDA, V.A.; MINASHINA, N.G., op. cit., p. 18.
} 
Comparado aos condicionadores orgânicos o gesso foi bem mais eficiente na redução da PST do solo o que está de acordo com Singh \& Singh (1989) e, tal como os resultados de Dubey \& Mondal (1994) a combinação organo-mineral foi benéfica.

Ao contrário do observado por Silva (1978) e Pereira et al., (1985) o efeito do gesso não ficou restrito à profundidade de aplicação; se estendeu até cerca de $60 \mathrm{~cm}$ de profundidade muito embora, em menor intensidade. A causa da diferença reside principalmente no período de avaliação adotado pelos referidos autores, inferior a um ano.

Quanto ao efeito residual do gesso na PST, variou com a dose, manejo adotado e intensidade de uso da terra. Com o solo pouco explorado e sem subsolagem há indícios que levam a admitir um efeito residual próximo de 5 anos com doses de 20 e 30 Mg.ha ${ }^{-1}$ de gesso (Figura 4 ) por outro lado, com 4 cultivos em três anos, sob subsolagem e inundação, aos 40 meses da aplicação do gesso já não se observa o efeito na PST (Figuras 5 e e $5 f$ ) e, os menores valores observados, em relação ao início do experimento, são atribuídos ao efeito de manejo, fato confirmado na testemunha. $O$ efeito residual do gesso na PST situa-se entre 2 e 4 anos conforme Alawi et al. ${ }^{4}$, citados por Pereira et al., (1985) e Rasmussen et al., (1978) respectivamente.

\subsubsection{Preparo do solo}

Não há dúvida de que a variável de efeito mais pronunciado e persistente para redução da PST do solo foi a subsolagem. Em todas as épocas analisadas a PST média no solo subsolado foi inferior a do solo não subsolado, pelo teste - $F(P<0,05$; Apêndice 4), com diminuição em valores absolutos de até $14 \%$.

A vantagem da subsolagem é bem nítida quando se compara as figuras $5 \mathrm{a}$ com $5 b$ e $5 c$ com $5 d$ em que, nas segundas não ocorre a formação de feixes de curvas com separação das que representam os condicionadores orgânicos e testemunha das com gesso e combinações. Também, assinalam valores de PST geralmente menores que 20 na camada de $0-15 \mathrm{~cm}$, independente do uso de condicionadores.

\footnotetext{
${ }^{4}$ ALAWI, et al., op. cit., p. 13.
} 
Ao se associar a subsolagem ao cultivo do arroz em bacias de inundação o efeito foi marcante em todo o perfil do solo, exceto para os condicionadores orgânicos isolados, registrando-se PST máximas no intervalo de 35 a $40 \%$ enquanto, sem subsolagem, os valores situaram-se entre 55 e $60 \%$ (Figuras 5 e e $5 f$ ).

Considerando apenas os valores de PST obtidos na testemunha, aos 9 meses do início do experimento observa-se na camada de $0-15 \mathrm{~cm}$ uma redução de $36 \%$ para 18\% com subsolagem, culminando aos 40 meses em 13,5\% inundado e não subsolado e 7,4\% ao se inundar e subsolar. Estes resultados confirmam as pesquisas de Abrol \& Bhumbla (1979) e Gheyi et al. (1995) nas quais concluem que independente do uso de condicionadores a PST é reduzida em solos inundados e cultivados com arroz. Este trabalho, permite acrescentar que a inundação é essencial para a redução da PST porém, não é uma prática imprescindível pois, a subsolagem, mesmo sem inundação provocou expressivas reduções na PST, estatisticamente comprovadas. Com as duas juntas porém, há redução muito mais expressiva da PST.

O bom desempenho da subsolagem vem reforçar a hipótese de existência de camadas de baixa permeabilidade a maiores profundidades do solo, se constituindo na condição mais limitante para a obtenção de melhorias como a redução da PST. A subsolagem, rompendo parte dessas camadas, favorece o deslocamento da água e sais para camadas mais profundas e, pela seletividade iônica com o estabelecimento de sucessivos equilíbrios pela permuta de cátions solubilizados do próprio solo o problema se ameniza. Concorda-se, em parte, com Ghassemi et al. (1995) de que se necessita de alto volume de água associado a um eficiente cultivo para, de forma lenta, reduzir a PST do solo. Entretanto, com os resultados do presente trabalho pode-se admitir que em solos salino-sódicos com condições físicas semelhantes ao que foi trabalhado, se associando subsolagem, irrigação por inundação e cultivo de arroz, em no máximo dois ciclos de exploração da cultura serão conseguidas apreciáveis reduções da PST até 45$60 \mathrm{~cm}$ de profundidade. $\mathrm{O}$ arroz indiretamente reduz à sodicidade devido ao aumento da porosidade decorrente da morte e renovação de raízes e possível solubilização de $\mathrm{CaCO}_{3}$ pela liberação de $\mathrm{CO}_{2}$ (Abrol \& Bhumbla, 1979 e Singh \& Singh 1989). 
Sob irrigação por aspersão a subsolagem associada a gessagem acelerou a redução da PST à semelhança dos resultados de El Mowelhi et al. ${ }^{5}$. citados por Pereira et al. (1985) e Silva (1978). No entanto, o mesmo não ocorreu quando se irrigou o solo por inundação, há 40 meses da gessagem. O efeito do gesso na PST, nessa época já havia cessado quer por esgotamento do resíduo ou pela solubilização natural de cálcio do solo nas áreas sem gessagem (testemunha).

A salinidade do solo foi de fácil correção, bastou inundar. O solo porém continua sódico para qualquer classificação (Richards, 1974; Pizarro, 1985; Estados Unidos, 1990 e Oliveira et al., 1992). Parece até impossivel remover tanto sódio num perfil de $2 \mathrm{~m}$ de profundidade para tomar o solo não sódico (Estados Unidos, 1990) porém, o que realmente interessa é tornar a camada de solo de maior exploração radicular em condição saudável a exploração de culturas e, às técnicas empregadas seguramente tornam a empreitada possivel e viável pelo menos até $45-60 \mathrm{~cm}$ de profundidade.

\subsection{Cálcio trocável}

Sendo o gesso fonte de cálcio é óbvio que com o uso desse condicionador os teores trocáveis do elemento no solo aumentem e os resultados não podem ser diferentes dos obtidos por Silva (1978), Cavalcante (1984), Lucena (1986) e Santos (1995).

O efeito do gesso na concentração de cálcio trocável do solo, até 12 meses da aplicação, no ensaio de doses, ficou restrito a camada de incorporação (Figuras $6 \mathrm{a}$ e $6 \mathrm{~b})$; aos 30 meses no entanto ficou bem evidenciado o aumento de cálcio até 30$60 \mathrm{~cm}$ (Figura 6c) e aos 60 meses, embora existam alguns vestígios (Figura 6d) de aumento, pelo teste - $\mathrm{F}$ as concentrações médias não se diferenciam da testemunha $(\mathrm{P}<$ 0,05). A análise estatística das concentrações de cálcio no solo aos 12 meses da gessagem mostra que as médias obtidas para as diferentes doses de gesso não diferem entre si e que nas doses de 20 e $30 \mathrm{Mg} \cdot \mathrm{ha}^{-1}$ é superior a testemunha na profundidade de $0-30 \mathrm{~cm}$ e igual nas demais profundidades $(\mathrm{P}<0,05)$. A mesma interpretação é válida para a referida profundidade aos 30 meses da gessagem (Apêndice 5) entretanto, embora graficamente

\footnotetext{
${ }^{5}$ EL MOWELHI et al., op. cit., p.12.
} 

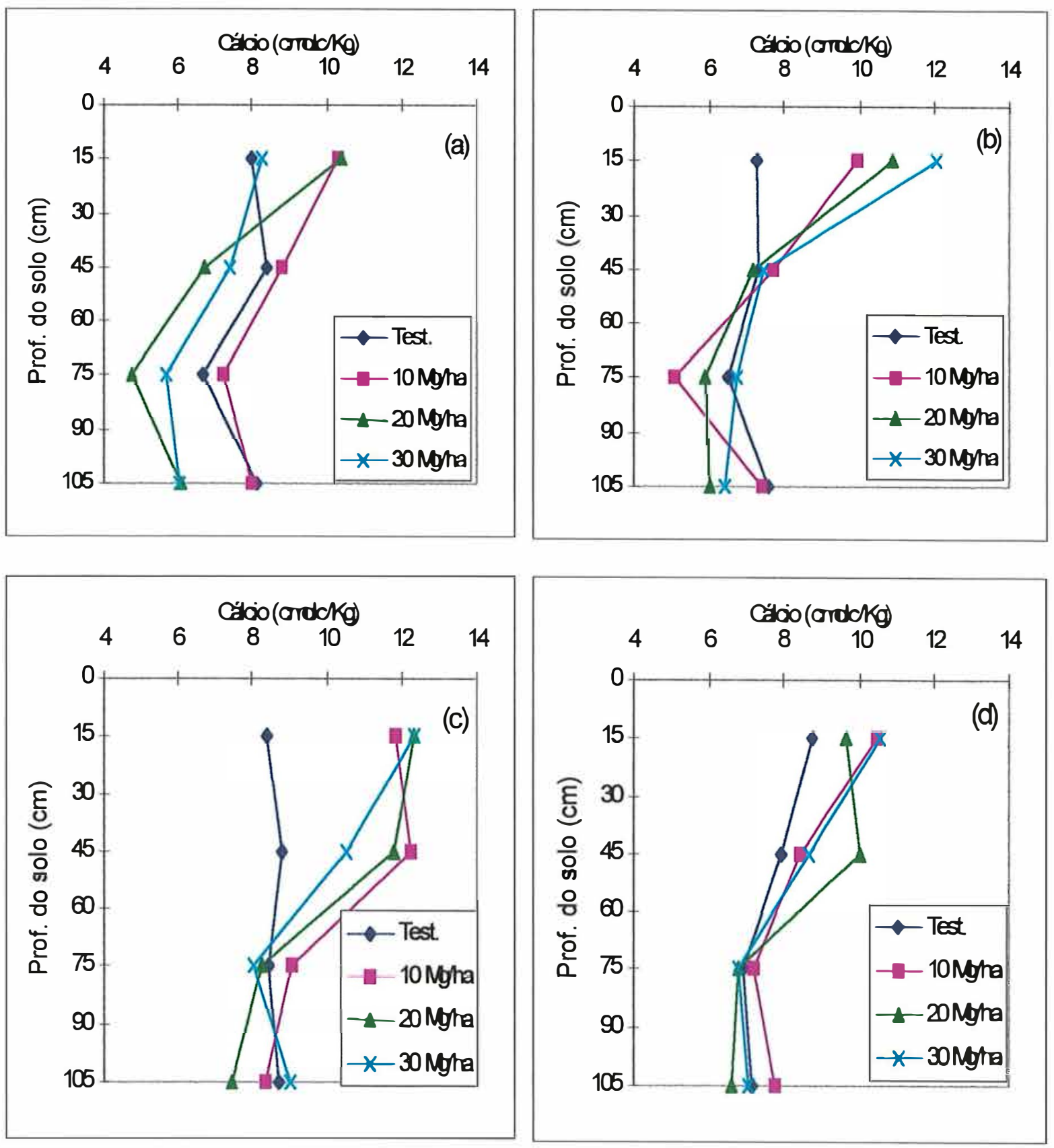

Figura 6 - Cálcio trocável em profundidade do solo, para as doses de $0,10,20$ e $30 \mathrm{Mg} \cdot \mathrm{ha}^{-1}$ de gesso, em 4 épocas após a aplicação : cálcio extraível após 6 meses (a), cálcio trocável após 12 meses (b), cálcio trocável após 30 meses (c) e cálcio trocável após 60 meses $(d)$. 
esteja claro (figura 6c) que na profundidade de $30-60 \mathrm{~cm}$ os tratamentos com gesso apresentam maiores concentrações de cálcio do que na testemunha, o teste de Tukey não confirma a diferença $(\mathrm{P}<0,05)$. Como $\mathrm{o}$ fato é tão evidente, interpreta-se o comportamento como de expressiva tendência de efeito do gesso no teor de cálcio trocável do solo em profundidades de até $30-60 \mathrm{~cm}$, aos 30 meses após a aplicação.

A contribuição dos resultados desse ensaio, quanto a variável em estudo, refere-se a viabilidade do uso do gesso em $1 / 3$ da necessidade estimada, em face de ter produzido o mesmo efeito que $2 / 3$ e recomendação integral. A solubilidade do gesso e a lixiviação não podem ser responsabilizadas pela ocorrência, restando portanto a alternativa de possivel precipitação do cálcio para formas menos disponíveis.

A subsolagem não exerceu efeito na concentração de cálcio no perfil do solo (Apêndice 6) o que não é novidade pois, prática mecânica não é fonte do elemento. Também, não interagiu com as outras variáveis estudadas, apresentando comportamento independente.

Nas figuras 7a e 7b, a exemplo da PST, observa-se novamente a formação de dois feixes de curvas, para as concentrações de cálcio, com a separação se acentuando em profundidade, a medida que o tempo transcorre, de 9 para 24 meses. Sem efeito de subsolagem, as figuras representam a média das duas situações e, todos os tratamentos contendo gesso, após 9 meses da aplicação, registraram concentrações de cálcio na profundidade de $0-15 \mathrm{~cm}$ do solo, superior ao da testemunha e aos obtidos sob o efeito dos condicionadores orgânicos sozinhos ( $\mathrm{P}<0,05$; Apêndice 6). Aos 24 meses (Figura 7b) se repetiram as diferenças do período anterior, na mesma profundidade e, nas duas abaixo se sobressaiu o gesso sozinho promovendo concentração de cálcio superior a obtida na testemunha mas que não difere dos valores nos tratamentos combinados $(\mathrm{P}<$ $0,05)$.

Nas determinações feitas há 40 meses do início do experimento, após a inundação do solo, não houve interação de condicionador $\mathrm{x}$ profundidade $\mathrm{e}$ as concentrações médias de cálcio trocável no perfil foram maiores para a combinação gesso mais esterco em relação a testemunha e palha isoladas. 

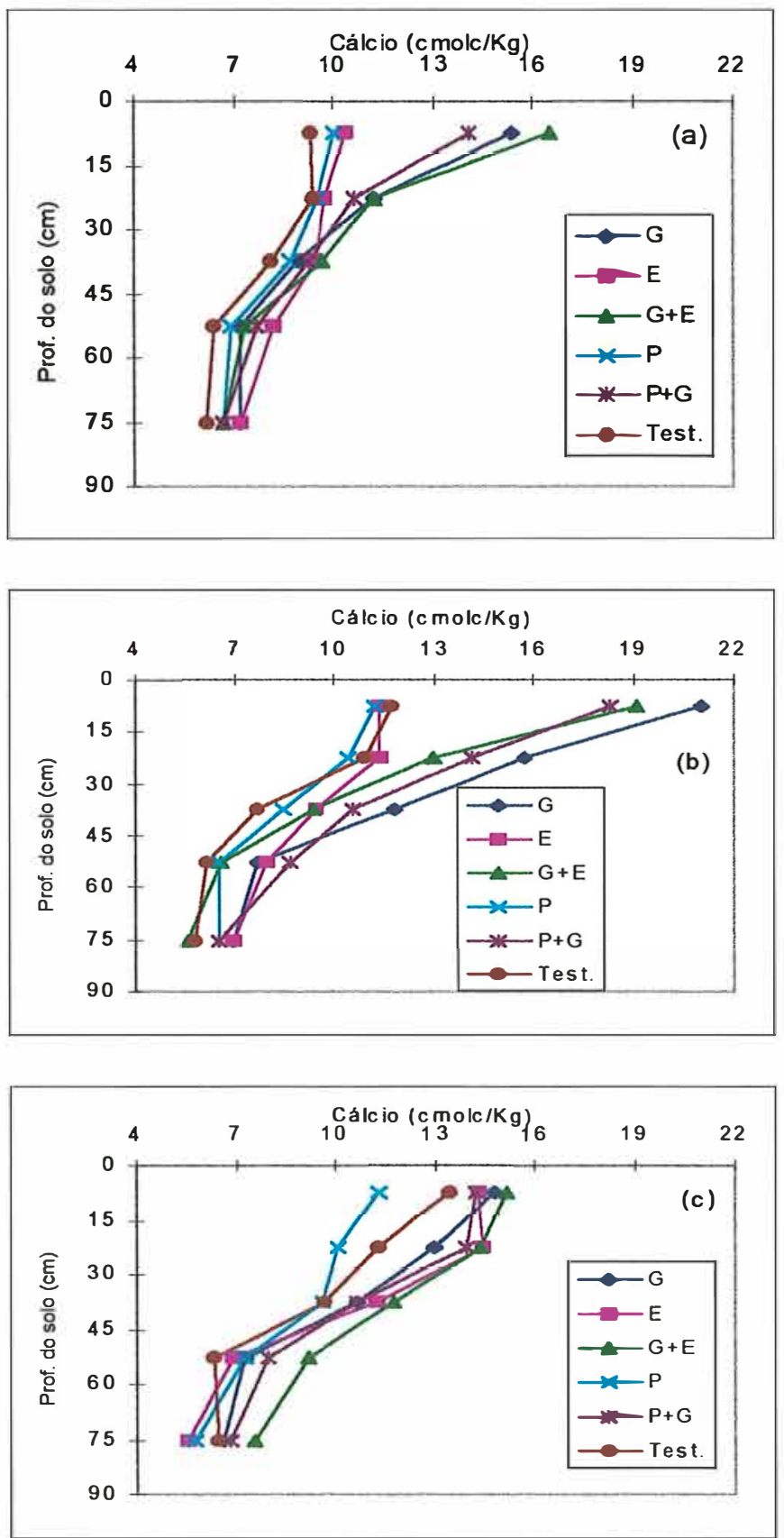

$(\mathrm{G})=$ gesso; $(\mathrm{E})=$ esterco; $(\mathrm{P})=$ palha de carnaúba; $($ Test $)=$ testemunha

Figura 7 - Cálcio trocável em profundidades do solo, em três épocas após a aplicação dos condicionadores: após nove meses (a), após 24 meses (b) e após 40 meses (c). 
Comparando-se as figuras $6 \mathrm{com}$ as 7 , vê-se comportamentos inversos no perfil do solo; enquanto nas primeiras as diferenças entre curvas se acentuam em profundidade, nas outras se aproximam. O cálcio e o sódio concorrem pelos mesmos sítios de troca catiônica de colóides do solo, e as concentrações não crescem ao mesmo tempo, funcionando o que determina a seletividade iônica e o nível populacional de cada um, cujo equilíbrio estabelecido pela relação de adsorção de sódio (RAS) indica a necessidade de muitos íons sódio para expulsar um único cálcio dos sítios de troca.

\subsection{Bases trocáveis e alcalinidade}

Os aumentos de cálcio trocável no solo, decorrentes do uso de condicionadores, foram correspondidos com menores valores de sódio trocável e concomitante diminuição da alcalinidade (Tabelas 8 e 9). $\mathrm{Na}$ área não subsolada, os valores de $\mathrm{pH}$ em profundidades de até $15-30 \mathrm{~cm}$ tendem a ser menores nos tratamentos com gesso indicando que esse condicionador contribui para o abaixamento do $\mathrm{pH}$. A concentração de sódio trocável guardou uma estreita relação com o $\mathrm{pH}$ do solo. Juntando-se os valores das duas tabelas, com os resultados há 24 meses da gessagem, foi ajustada a equação: $\mathrm{pH}=6,50+0,14[\mathrm{Na}] \operatorname{com}\left(\mathrm{R}^{2}=0,82\right)$.

Reduções mais expressivas no $\mathrm{pH}$ foram observadas na área subsolada, aparentemente sem guardar relação com os condicionadores aplicados (Tabela 8). A comparação entre os valores das duas tabelas parece admitir a hipótese de que para diminuição do $\mathrm{pH}$ as opções de subsolagem e gessagem são válidas e excludentes; ao se adotar a subsolagem não é necessário a gessagem e vice-versa.

As diminuições no $\mathrm{pH}$ do solo obtidas através da gessagem, conferem com observadas por diversos autores (Gupta \& Bajpai, 1977; Singh \& Singh, 1989; Dubey \& Mondal, 1994 e Santos, 1995). As explicações para o fenômeno compreendem: o gesso, favorecendo o deslocamento de bases trocáveis entre as quais sódio, para camadas mais profundas do solo, possibilita a ocupação de parte dos sítios de troca por hidrogênio proveniente da dissociação iônica da água; carbonatos e bicarbonatos, responsáveis pelo aumento da alcalinidade, saem de circulação formando complexos de baixa solubilidade com o cálcio e, o próprio aumento da concentração de eletrólitos na solução do solo 
baixa o $\mathrm{pH}$. A primeira justificativa é bem adequada para explicar o efeito da subsolagem no abaixamento do $\mathrm{pH}$.

Tabela 8 - Composição de cátions trocáveis no complexo sortivo do solo, em área sem subsolagem, 24 meses após a aplicação dos condicionadores, ensaio de métodos de correção de solo salino-sódico, médias de 4 repetições.

\begin{tabular}{|c|c|c|c|c|c|c|c|}
\hline \multirow{2}{*}{$\begin{array}{c}\text { Prof. Solo } \\
\text { (cm) }\end{array}$} & \multirow{2}{*}{$\begin{array}{c}\text { Tratamento } \\
\text { Condiciomador }\end{array}$} & \multirow{2}{*}{$\begin{array}{c}\mathrm{pH}(\text { água }) \\
1: 2,5\end{array}$} & \multicolumn{5}{|c|}{ CÁTIONS TROCĀVEIS $\left(\mathrm{cmol}_{\left.\mathrm{c} . \mathrm{kg}^{-1}\right)}\right.$} \\
\hline & & & $\mathrm{Ca}^{+2}$ & $\mathrm{Mg}^{+2}$ & $\mathrm{Na}^{+}$ & $\mathrm{K}^{+}$ & $\mathrm{H}^{+}$ \\
\hline $0-15$ & $\mathrm{G}$ & 7,0 & 22,74 & 3,68 & 1,99 & 1,46 & 0,88 \\
\hline $0-15$ & E & 7,9 & 13,02 & 4,61 & 7,27 & 1,03 & 0,73 \\
\hline $0-15$ & $\mathrm{G}+\mathrm{E}$ & 7,0 & 17,95 & 3,65 & 2,89 & 1,07 & 0,94 \\
\hline $0-15$ & $\mathrm{P}$ & 7,4 & 11,07 & 4,94 & 7,24 & 1,19 & 1,13 \\
\hline $0-15$ & $\mathrm{G}+\mathrm{P}$ & 6,8 & 21,13 & 3,42 & 2,76 & 1,13 & 1,20 \\
\hline $0-15$ & $\mathrm{~T}$ & 7,8 & 12,58 & 4,86 & 6,52 & 1,82 & 0,43 \\
\hline $15-30$ & G & 7,8 & 16,98 & 3,96 & 4,03 & 1,07 & 0,55 \\
\hline $15-30$ & $\mathrm{E}$ & 8,4 & 11,55 & 3,96 & 13,20 & 0,72 & 0,38 \\
\hline $15-30$ & $\mathrm{G}+\mathrm{E}$ & 7,3 & 12,96 & 4,11 & 7,65 & 0,76 & 1,07 \\
\hline $15-30$ & $\mathrm{P}$ & 8,0 & 9,56 & 4,14 & 12,93 & 0,75 & 0,57 \\
\hline $15-30$ & $\mathrm{G}+\mathrm{P}$ & 7,0 & 13,29 & 4,09 & 4,41 & 0,82 & 1,26 \\
\hline $15-30$ & $\mathrm{~T}$ & 8,3 & 11,92 & 4,07 & 11,74 & 1,27 & 0,38 \\
\hline $30-45$ & G & 8,6 & 12,78 & 3,55 & 13,77 & 0,71 & 0,34 \\
\hline $30-45$ & E & 8,6 & 9,05 & 3,06 & 17,81 & 0,59 & 0,32 \\
\hline $30-45$ & $\mathrm{G}+\mathrm{E}$ & 8,0 & 9,04 & 3,50 & 13,00 & 0,75 & 0,62 \\
\hline $30-45$ & $\mathrm{P}$ & 8,5 & 7,44 & 3,28 & 16,46 & 0,67 & 0,08 \\
\hline $30-45$ & $\mathrm{G}+\mathrm{P}$ & 7,8 & 9,18 & 3,70 & 8,97 & 0,57 & 0,72 \\
\hline $30-45$ & $\mathrm{~T}$ & 8,6 & 7,33 & 3,05 & 14,35 & 0,78 & 0,21 \\
\hline $45-60$ & G & 8,9 & 7,75 & 2,51 & 16,71 & 0,68 & 0,15 \\
\hline $45-60$ & $\mathrm{E}$ & 8,8 & 7,65 & 2,53 & 17,70 & 0,60 & 0,17 \\
\hline $45-60$ & $\mathrm{G}+\mathrm{E}$ & 8,4 & 6,18 & 2,78 & 14,55 & 0,67 & 0,43 \\
\hline $45-60$ & $\mathrm{P}$ & 8,8 & 5,51 & 2,85 & 16,37 & 0,64 & 0,23 \\
\hline $45-60$ & $\mathrm{G}+\mathrm{P}$ & 8,1 & 7,20 & 3,24 & 11,01 & 0,63 & 0,55 \\
\hline $45-60$ & $\mathrm{~T}$ & 8,9 & 6,31 & 2,44 & 13,11 & 0,71 & 0,06 \\
\hline $60-90$ & G & 9,1 & 7,39 & 2,35 & 17,67 & 0,64 & 0,08 \\
\hline $60-90$ & E & 9,0 & 7,64 & 2,03 & 14,47 & 0,61 & 0,10 \\
\hline $60-90$ & $\mathrm{G}+\mathrm{E}$ & 8,6 & 5,29 & 2,58 & 14,01 & 0,60 & 0,30 \\
\hline $60-90$ & $\mathrm{P}$ & 9,1 & 5,75 & 2,58 & 16,36 & 0,58 & 0,00 \\
\hline $60-90$ & $\mathrm{G}+\mathrm{P}$ & 8,3 & 5,88 & 2,99 & 11,49 & 0,61 & 0,38 \\
\hline $60-90$ & $\mathrm{~T}$ & 9,1 & 6,82 & 2,38 & 13,97 & 0,62 & 0,04 \\
\hline
\end{tabular}


Tabela 9 - Composição de cátions trocáveis no complexo sortivo do solo, em área subsolada, 24 meses após a aplicação dos condicionadores, ensaio de métodos de correção de solo salino-sódico, médias de 4 repetições.

\begin{tabular}{|c|c|c|c|c|c|c|c|}
\hline \multirow{2}{*}{$\begin{array}{l}\text { Prof. Solo } \\
\text { (cm) }\end{array}$} & \multirow{2}{*}{$\begin{array}{c}\text { Tratamento } \\
\text { Condicionador }\end{array}$} & \multirow{2}{*}{$\begin{array}{c}\mathrm{pH}(\mathrm{a} g u a) \\
1: 2,5\end{array}$} & \multicolumn{5}{|c|}{ CÁTIONS TROCÁVEIS $\left(\mathrm{cmol}^{\circ} \cdot \mathrm{kg}^{-1}\right)$} \\
\hline & & & $\mathrm{Ca}^{+2}$ & $\mathrm{Mg}^{+2}$ & $\mathrm{Na}^{+}$ & $\mathrm{K}^{+}$ & $\mathrm{H}^{+}$ \\
\hline $0-15$ & $\mathrm{G}$ & 6,9 & 19,28 & 4,06 & 1,84 & 1,17 & 0,94 \\
\hline $0-15$ & E & 7,1 & 11,86 & 5,38 & 3,30 & 1,13 & 1,26 \\
\hline $0-15$ & $G+E$ & 6,7 & 20,20 & 4,20 & 1,84 & 0,95 & 1,26 \\
\hline $0-15$ & $\mathrm{P}$ & 7,1 & 11,38 & 5,07 & 4,30 & 1,07 & 1,09 \\
\hline $0-15$ & $\mathrm{G}+\mathrm{P}$ & 6,9 & 19,59 & 3,66 & 1,72 & 1,19 & 1,11 \\
\hline $0-15$ & $\mathrm{~T}$ & 7,0 & 10,84 & 5,30 & 4,41 & 0,98 & 1,32 \\
\hline $15-30$ & G & 7,2 & 14,43 & 4,43 & 4,27 & 0,97 & 1,00 \\
\hline $15-30$ & $\mathrm{E}$ & 7,0 & 11,30 & 5,06 & 6,40 & 0,92 & 1,47 \\
\hline $15-30$ & $\mathrm{G}+\mathrm{E}$ & 6,8 & 13,02 & 4,45 & 6,43 & 0,72 & 1,48 \\
\hline $15-30$ & $\mathrm{P}$ & 7,2 & 11,35 & 5,03 & 6,59 & 0,76 & 1,03 \\
\hline $15-30$ & $\mathrm{G}+\mathrm{P}$ & 6,9 & 14,88 & 4,54 & 3,27 & 0,99 & 1,16 \\
\hline $15-30$ & $\mathrm{~T}$ & 7,3 & 9,94 & 4,89 & 8,62 & 0,64 & 1,09 \\
\hline $30-45$ & G & 7,8 & 10,84 & 4,19 & 10,04 & 0,69 & 0,60 \\
\hline $30-45$ & E & 7,2 & 9,83 & 4,66 & 8,55 & 0,70 & 1,15 \\
\hline $30-45$ & $\mathrm{G}+\mathrm{E}$ & 7,3 & 9,69 & 4,31 & 11,03 & 0,49 & 0,87 \\
\hline $30-45$ & $\mathrm{P}$ & 7,3 & 9,5 & 4,20 & 7,94 & 0,51 & 1,20 \\
\hline $30-45$ & $\mathrm{G}+\mathrm{P}$ & 7,3 & 12,08 & 4,97 & 6,82 & 0,60 & 1,17 \\
\hline $30-45$ & $\mathrm{~T}$ & 7,9 & 8,03 & 4,00 & 12,59 & 0,51 & 0,81 \\
\hline $45-60$ & G & 8,3 & 7,52 & 3,67 & 14,69 & 0,75 & 0,34 \\
\hline $45-60$ & $\mathrm{E}$ & 7,5 & 8,19 & 4,29 & 8,56 & 0,60 & 0,77 \\
\hline $45-60$ & $\mathrm{G}+\mathrm{E}$ & 7,7 & 7,04 & 3,43 & 10,65 & 0,46 & 0,49 \\
\hline $45-60$ & $\mathrm{P}$ & 7,5 & 7,45 & 3,72 & 8,21 & 0,51 & 0,64 \\
\hline $45-60$ & $\mathrm{G}+\mathrm{P}$ & 7,8 & 10,07 & 4,57 & 8,35 & 0,55 & 0,60 \\
\hline $45-60$ & $\mathrm{~T}$ & 8,2 & 5,98 & 3,19 & 13,02 & 0,49 & 0,28 \\
\hline $60-90$ & G & 8,6 & 6,43 & 3,00 & 13,65 & 0,72 & 0,21 \\
\hline $60-90$ & E & 7,6 & 6,47 & 3,42 & 7,08 & 0,55 & 0,60 \\
\hline $60-90$ & $G+E$ & 8,0 & 5,92 & 3,13 & 11,72 & 0,46 & 0,29 \\
\hline $60-90$ & $\mathrm{P}$ & 7,7 & 7,23 & 3,76 & 9,20 & 0,46 & 0,60 \\
\hline $60-90$ & $\mathrm{G}+\mathrm{P}$ & 8,2 & 7,10 & 3,41 & 10,29 & 0,53 & 0,28 \\
\hline $60-90$ & $\mathrm{~T}$ & 8,5 & 4,77 & 2,79 & 10,82 & 0,57 & 0,13 \\
\hline
\end{tabular}

${ }^{1} \mathrm{G}=$ Gesso; $\mathrm{E}=$ Esterco de curral: $\mathrm{P}=$ Palha de carnaúba; $\mathrm{T}=$ testemunha

Existem algumas evidências para as duas situações de preparo do solo de que parte do cálcio oriundo do gesso pode ter substituído o magnésio trocável na camada de $0-15 \mathrm{~cm}$. Comparando as concentrações desse elemento no tratamento só com gesso e na testemunha, observa-se, em valores absolutos, uma diminuição de até $1,24 \mathrm{cmol}_{\mathrm{c}} \cdot \mathrm{kg}^{-1}$ 
do primeiro para o segundo (Tabelas 8 e 9). Reduções de magnésio trocável decorrentes do uso do gesso também foram constatadas por Armstrong \& Tanton (1993) e Santos (1995) e são perfeitamente justificáveis pela seletividade iônica. Em termos de cátions trocáveis o cálcio é menos fortemente adsorvido que $\mathrm{H}^{0} \mathrm{e} \mathrm{Al}^{3+}$, na competição por sítios de troca, em condições de igualdade e, estando em concentrações elevadas o alumínio é trocado pelo cálcio como acontece na correção de solos ácidos através da calagem. O magnésio sendo de menor seletividade pode ser substituído em decorrência da concentração e força ionica do cálcio.

Considerando a riqueza em potássio trocável dos solos aluviais do Baixo Açu, com determinações próximas até dos $2 \mathrm{cmol}_{c} \cdot \mathrm{kg}^{-1}$, os laboratórios de análise de solo geralmente não recomendam adubação potássica. Um detalhe porém é esquecido: como vai a relação de cátions na CTC ?. Aos 24 meses, nas duas primeiras camadas de solo, pelos valores das tabelas 8 e 9, a relação $\mathrm{K}: \mathrm{Ca}: \mathrm{Mg}$ variou entre 1:9:3 a 1:21:4. Até aí está razoável entretanto, após 40 meses do início do experimento, sob efeito dos tratamentos, inundação e consumo pelos cultivos, as concentrações de potássio situavam-se a menos da metade detectada aos 24 meses e foram calculadas relações de até 1:60:20 o que passa a ser preocupante com o desequilíbrio do potássio no solo podendo causar problemas nutricionais na planta. A testemunha apresentou a maior relação de adsorção de potássio na profundidade de $0-15 \mathrm{~cm}$ do solo, na determinação após 24 meses do início do experimento (tabelas 8 e 9). $\mathrm{O}$ aumento de $\mathrm{K}$ trocável observado em relação aos valores iniciais pode estar associado a solubilização desse elemento, de fontes minerais como argilas 2:1, micas e feldspatos, presentes com freqüência nesses ambientes aluvionais. Como o pH é elevado, constata-se freqüentemente sintomas de carência de zinco na exploração de citros em solos aluvionais do Baixo Açu, cuja deficiência foi comprovada através de análise foliar realizada no laboratório da EMPARN.

\subsection{Balanço iônico}

Através do balanço iônico no extrato saturado do solo constata-se que o ânion predominante é o cloro, formando par com o sódio que predomina entre os cátions. 
Comparando os valores das Tabelas 10 e 11 observa-se nítida diferença no somatório de cátions e ânions da área subsolada, com valores médios no perfil correspondendo entre $80 \%$ e $48 \%$ do total da área não subsolada, sendo os valores mais próximos observados nos tratamentos contendo palha de carnaúba. As menores quantidades de sais na área subsolada, em particular até a ausência de carbonatos, pode estar relacionada ao maior aporte de água dada a maior infiltração, criando mais oportunidades de deslocamentos no perfil e ficando fora da profundidade amostrada.

O sulfato, em maior concentração na solução do solo no tratamento só com gesso, está presente em camadas de até $60-90 \mathrm{~cm}$, na área não subsolada e não há dúvida que o seu parceiro na descida foi o sódio na formação do par iônico (Tabela 10). $\mathrm{Na}$ área subsolada tudo indica que o deslocamento foi além dos $90 \mathrm{~cm}$, não sendo detectado na amostragem aos 40 meses (Tabela 11).

Os valores de RAS foram amenizados na área subsolada situando-se no intervalo de 3 a 40 enquanto sem subsolagem ficou entre 6 e 70 mesmo assim, em nenhum caso foi perdida a condição de sodicidade do solo (Estados Unidos, 1990).

Os maiores valores de sódio e cloreto solúveis foram determinados nos tratamentos em que o condicionador foi a palha de carnaúba chegando a atingir respectivamente valores de 44 e $38 \mathrm{mmol}_{\mathrm{c}} \mathrm{L}^{-1}$ concordando com Kovda \& Minashina ${ }^{6}$ citados por Szabolcs (1989) quando advertem do risco da aplicação no solo de resíduos orgânicos dessa natureza. Como se trata de material orgânico grosseiro, de lenta decomposição, a retenção de umidade onde se incorporou a palha apresentou valores mais elevados, até $762 \mathrm{~g}$ de água por $\mathrm{kg}$ de solo (Tabela 10).

\subsection{Efeito na produção vegetal}

A principal interessada em que o solo esteja em condições adequadas, permitindo um desenvolvimento saudável. é a própria cultura, que responde com aumento de produção.

Aos resultados de produção de algodão e arroz obtidos no ensaio de doses de gesso foi ajustado o modelo descontínuo em platô - linear response plateau (LRP),

\footnotetext{
${ }^{6}$ KOVDA, V.A.; MINASHINA, N.G., op. cit., p. 18.
} 
Tabela 10 - Balanço iônico na solução do solo (extrato saturado) em área sem subsolagem, 40 meses após a aplicação dos condicionadores, ensaio de métodos de recuperação de solo salino-sódico, médias de 4 repetições.

\begin{tabular}{|c|c|c|c|c|c|c|c|c|c|c|c|c|c|}
\hline \multirow{2}{*}{$\begin{array}{l}\text { Prof. } \\
(\mathrm{cm})\end{array}$} & \multirow{2}{*}{$\begin{array}{c}\text { Trata- } \\
\text { mento }^{(1)}\end{array}$} & \multicolumn{4}{|c|}{ Ânions $\left(\mathrm{mmol}_{\mathrm{c}} \cdot \mathrm{L}^{-1}\right)$} & \multicolumn{4}{|c|}{ Cátions $\left(\mathrm{mmol}_{\left.\mathrm{c} . \mathrm{L}^{-1}\right)}\right.$} & \multirow{2}{*}{$\sum_{\text {Ânion }}^{\sum}$} & \multirow{2}{*}{$\sum_{\text {Cátion }}$} & \multirow{2}{*}{$\begin{array}{l}\text { RAS } \\
(2)\end{array}$} & \multirow{2}{*}{$\begin{array}{c}\mathrm{Umid}^{(3)} \\
\mathrm{g} \cdot \mathrm{kg}^{-1}\end{array}$} \\
\hline & & $\mathrm{CO}_{3}{ }^{2-}$ & $\mathrm{HCO}_{3}^{-}$ & $\mathrm{Cl}^{-}$ & $\mathrm{SO}_{4}{ }^{2-}$ & $\mathrm{Ca}^{2+}$ & $\mathrm{Mg}^{2+}$ & $\mathrm{Na}^{+}$ & $\overline{\mathrm{K}^{+}}$ & & & & \\
\hline $0-15$ & $\mathrm{G}$ & 0.25 & 4,44 & 5,42 & 14,85 & 8,45 & 2,07 & 13,96 & 0,19 & 24,95 & 24.67 & 6,09 & 581,3 \\
\hline $0-15$ & $\mathrm{E}$ & 0,48 & 5,68 & 7,76 & 6,78 & 3,80 & 1,45 & 15,39 & 0,19 & 20,69 & 20,82 & 9,50 & 634,1 \\
\hline $0-15$ & $\mathrm{G}+\mathrm{E}$ & 0,75 & 4,96 & 6,02 & 4,53 & 2,45 & 1,16 & 13,21 & 0,21 & 16,25 & 17.03 & 9,83 & 590,4 \\
\hline $0-15$ & $\mathrm{P}$ & 1,08 & 6,90 & 9,02 & 5,49 & 0,86 & 0,78 & 19,48 & 0,13 & 22,48 & 21.25 & 21,51 & 650,2 \\
\hline $0-15$ & $\mathrm{G}+\mathrm{P}$ & 0,20 & 4,85 & 5,53 & 4,48 & 1,46 & 0,81 & 12,64 & 0,17 & 15,06 & 15.07 & 11,86 & 581,7 \\
\hline $0-15$ & $\mathrm{~T}$ & 0,03 & 2,16 & 5,34 & 13,17 & 5,68 & 2,20 & 13,69 & 0,21 & 20,69 & 21,78 & 6,90 & 590,6 \\
\hline $15-30$ & G & 0,28 & 4,83 & 4,37 & 17,68 & 4,56 & 1,53 & 19,15 & 0,12 & 27,15 & 25.35 & 10,97 & 577,9 \\
\hline $15-30$ & $E$ & 0,65 & 5,31 & 8,26 & 6,46 & 0,92 & 0,70 & 18,68 & 0,09 & 20,68 & 20,38 & 20,75 & 597,1 \\
\hline $15-30$ & $\mathrm{G}+\mathrm{E}$ & 0,63 & 4,24 & 5,42 & 5,74 & 1,17 & 0,66 & 13,01 & 0,10 & 16,02 & 14,93 & 13,60 & 611,6 \\
\hline $15-30$ & $\mathrm{P}$ & 0,80 & 6,61 & 7,23 & 4,80 & 0,67 & 0,61 & 17,44 & 0,13 & 19,44 & 18.85 & 21,80 & 678,9 \\
\hline $15-30$ & $\mathrm{G}+\mathrm{P}$ & 0,78 & 5,45 & 6,44 & 4,54 & 0,72 & 0,49 & 16,53 & 0,15 & 17,21 & 17.88 & 21,25 & 577,1 \\
\hline $15-30$ & $\mathrm{~T}$ & 0,20 & 3,26 & 4,65 & 11,23 & 2,48 & 1.23 & 15,23 & 0,16 & 19,34 & 19,10 & 11,18 & 602,3 \\
\hline $30-45$ & G & 0,33 & 4,34 & 3.46 & 10,98 & 0,92 & 0,71 & 16,58 & 0.12 & 19,10 & 18,33 & 18,37 & 542,2 \\
\hline $30-45$ & $E$ & 0,20 & 4,34 & 10,38 & 6,91 & 0,50 & 0,39 & 21,08 & 0,11 & 21,83 & 22,08 & 31,60 & 560,1 \\
\hline $30-45$ & $\mathrm{G}+\mathrm{E}$ & 0,80 & 5,86 & 5,50 & 5,02 & 0,36 & 0,28 & 15,57 & 0,07 & 17,18 & 16.28 & 27,52 & 615,0 \\
\hline $30-45$ & $\mathrm{P}$ & 0,48 & 5,00 & 15,15 & 4,05 & 0,49 & 0,37 & 23,45 & 0.05 & 24,67 & 24,36 & 35,76 & 673,7 \\
\hline $30-45$ & $\mathrm{G}+\mathrm{P}$ & 0,23 & 3,68 & 7,91 & 4,03 & 0,56 & 0,38 & 15,15 & 0,16 & 15,84 & 16.25 & 22,10 & 538,1 \\
\hline $30-45$ & $T$ & 0,28 & 3,54 & 4,60 & 7,72 & 0,67 & 0,36 & 14,32 & 0,14 & 16,13 & 15,49 & 19,95 & 558,9 \\
\hline $45-60$ & G & 0.33 & 4,70 & 4,51 & 12,00 & 0,47 & 0,45 & 19,72 & 0,31 & 21,53 & 20.94 & 32,87 & 568,0 \\
\hline $45-60$ & $\mathrm{E}$ & 0,50 & 5,31 & 8,91 & 5,02 & 0,38 & 0,27 & 19,40 & 0.06 & 19,75 & 20,12 & 34,03 & 638,2 \\
\hline $45-60$ & $\mathrm{G}+\mathrm{E}$ & 0.50 & 5,56 & 8,09 & 4,12 & 0,45 & 0,32 & 17,62 & 0.12 & 18,27 & 18.51 & 28,40 & 648,4 \\
\hline $45-60$ & $\mathrm{P}$ & 0.43 & 4,66 & 25,94 & 2,87 & 0,56 & 0,42 & 32,18 & 0,07 & 33,89 & 33,23 & 45,97 & 713,9 \\
\hline $45-60$ & $\mathrm{G}+\mathrm{P}$ & 0,28 & 3,55 & 13,22 & 4,12 & 0.60 & 0,45 & 21,55 & 0,09 & 21,17 & 22.69 & 29,74 & 604,3 \\
\hline $45-60$ & $\mathrm{~T}$ & 0,23 & 3,88 & 5,79 & 6,19 & 0,42 & 0,33 & 15,67 & 0,14 & 16,08 & 15,56 & 25,59 & 594,8 \\
\hline $60-90$ & $\mathrm{G}$ & 0.38 & 4,51 & 7,41 & 16,14 & 0,42 & 0.36 & 27.36 & 0.05 & 28,44 & 28,19 & 43,81 & 643,2 \\
\hline $60-90$ & $\mathrm{E}$ & 0,48 & 5,71 & 8,21 & 5,16 & 0,45 & 0,28 & 17,86 & 0.06 & 19,55 & 18,65 & 29,56 & 626,8 \\
\hline $60-90$ & $\mathrm{G}+\mathrm{E}$ & 0.78 & 5,99 & 12,17 & 4,93 & 0,50 & 0,31 & 23,52 & 0.09 & 23,87 & 24.40 & 36,96 & 660,6 \\
\hline $60-90$ & $\mathrm{P}$ & 0,18 & 3,75 & 37,91 & 4,35 & 0,41 & 0,40 & 44,16 & 0.06 & 46,18 & 45.02 & 69,39 & 762,4 \\
\hline $60-90$ & $\mathrm{G}+\mathrm{P}$ & 0.33 & 3,64 & 31,29 & 4.66 & 0,91 & 0,76 & 39,91 & 0.07 & 39,91 & +1.66 & 43,68 & 648,2 \\
\hline $60-90$ & $\mathrm{~T}$ & 0,50 & 5,06 & 14,61 & 6.01 & 0,67 & 0,44 & 25.51 & 0.08 & 26.19 & 26.70 & 34,24 & 675.5 \\
\hline
\end{tabular}


Tabela 11 - Balanço iônico na solução do solo (extrato saturado) em área subsolada, 40 meses após a aplicação dos condicionadores, ensaio de métodos de recuperação de solo salino-sódico, médias de 4 repetições.

\begin{tabular}{|c|c|c|c|c|c|c|c|c|c|c|c|c|c|}
\hline \multirow{2}{*}{$\begin{array}{l}\text { Prof. } \\
\text { (cm) }\end{array}$} & \multirow{2}{*}{$\begin{array}{c}\text { Trata- } \\
\text { mento }^{(1)}\end{array}$} & \multicolumn{4}{|c|}{ Ânions $\left(\mathrm{mmol}_{\mathrm{c}} \cdot \mathrm{L}^{-1}\right)$} & \multicolumn{4}{|c|}{ Cátions $\left(\mathrm{mmol}_{\mathrm{c}} \mathrm{L}^{-1}\right)$} & \multirow{2}{*}{$\underset{\text { Ânion }}{\sum}$} & \multirow{2}{*}{$\sum_{\text {Cátion }}$} & \multirow{2}{*}{$\begin{array}{l}\text { RAS } \\
(2)\end{array}$} & \multirow{2}{*}{$\frac{\mathrm{Umid}^{(3)}}{\mathrm{g.kg}^{-1}}$} \\
\hline & & $\mathrm{CO}_{3}{ }^{2-}$ & $\mathrm{HCO}_{3}{ }^{\circ}$ & $\mathrm{Cl}^{-}$ & $\mathrm{SO}_{4}{ }^{2-}$ & $\mathrm{Ca}^{2-}$ & $\mathrm{Mg}^{2-}$ & $\mathrm{Na}$ & $\mathrm{K}^{+}$ & & & & \\
\hline $0-15$ & $\mathrm{G}$ & 0,25 & 4,55 & 6,14 & 3,87 & 1,78 & 1.04 & 11.46 & 0,15 & 14,55 & 14,42 & 9,65 & 555,8 \\
\hline $0-15$ & $\mathrm{E}$ & 0,10 & 3,21 & 5,35 & 5,89 & 4,52 & 1,44 & 9.43 & 0,15 & 14,55 & 15,53 & 5,46 & 515,9 \\
\hline $0-15$ & $\mathrm{G}+\mathrm{E}$ & 0,05 & 3,51 & 4,66 & 4,05 & 4,06 & 1,52 & 6,48 & 0,16 & 12,27 & 12,22 & 3,88 & 562.8 \\
\hline $0-15$ & $\mathrm{P}$ & 0,13 & 3,21 & 10,20 & 5,44 & 2,96 & 1,69 & 14,61 & 0,18 & 19,00 & 19,43 & 9,58 & 574,9 \\
\hline $0-15$ & $\mathrm{G}+\mathrm{P}$ & 0,10 & 3,14 & 4,20 & 12,97 & 9.36 & 2.66 & 8,16 & 0,21 & 20,41 & 20,39 & 3,33 & 558,9 \\
\hline $0-15$ & $T$ & 0,05 & 3,05 & 4,09 & 5,37 & 3,68 & 1,59 & 7.25 & 0,18 & 12,56 & 12,70 & 4,47 & 555,8 \\
\hline $15-30$ & G & 0,10 & 3,65 & 6,74 & 5,64 & 1.32 & 0,88 & 14,10 & 0,11 & 16,12 & 16,40 & 13,44 & 567,8 \\
\hline $15-30$ & E & 0,18 & 3,25 & 3,30 & 4,52 & 3,14 & 1,17 & 6,45 & 0,15 & 11,25 & 10,91 & 4,39 & 553,2 \\
\hline $15-30$ & $\mathrm{G}+\mathrm{E}$ & 0 & 2,71 & 1,93 & 2,87 & 1.91 & 0.87 & 4.84 & 0,11 & 7,50 & 7,73 & 4,11 & 517,0 \\
\hline $15-30$ & $\mathrm{P}$ & 0,05 & 2,49 & 10,60 & 6,01 & 1.43 & 1,09 & 16.38 & 0,27 & 19,10 & 19,16 & 14,59 & 585,8 \\
\hline $15-30$ & $\mathrm{G}+\mathrm{P}$ & 0,05 & 1,98 & 2,00 & 10,32 & 5,79 & 2,04 & 7,42 & 0,14 & 14,35 & 15,39 & 3.75 & 579.6 \\
\hline $15-30$ & $T$ & 0 & 2,43 & 1,73 & 2,37 & 0,62 & 0,49 & 4,62 & 0,11 & 6,53 & 5,84 & 6,20 & 545,2 \\
\hline $30-45$ & G & 0 & 2.33 & 5.18 & 3,96 & 0,84 & 0,62 & 9.06 & 0,12 & 11,46 & 10,62 & 12,41 & 495,4 \\
\hline $30-45$ & $\mathrm{E}$ & 0,15 & 3,13 & 1,74 & 4,91 & 0,53 & 0,34 & 7,97 & 0,09 & 9,92 & 8,92 & 12,08 & 526.5 \\
\hline $30-45$ & $G+E$ & 0 & 1,78 & 1,91 & 3,85 & 0,70 & 0,45 & 5.66 & 0,09 & 7,54 & 6,89 & 7,46 & 495,3 \\
\hline $30-45$ & $\mathrm{P}$ & 0,03 & 2,10 & 11,20 & 4,98 & 0,70 & 0,50 & 16.23 & 0,32 & 18,25 & 17,75 & 20,95 & 558,0 \\
\hline $30-45$ & $\mathrm{G}+\mathrm{P}$ & 0 & 1,33 & 1,99 & 6,75 & 0,88 & 0,53 & 8,23 & 0,15 & 10,06 & 9,79 & 9,80 & 544,2 \\
\hline $30-45$ & $\mathrm{~T}$ & 0,05 & 2,43 & 2,90 & 4,50 & 0,94 & 0,55 & 8.06 & 0,15 & 9,87 & 9,69 & 9,34 & 519,8 \\
\hline $45-60$ & G & 0 & 1,70 & 7,18 & 4,62 & 0,68 & 0,55 & 12.07 & 0,11 & 13,50 & 13,40 & 15,39 & 504,5 \\
\hline $45-60$ & E & 0,10 & 3,41 & 1,49 & 5,07 & 0,25 & 0,17 & 9,09 & 0,07 & 10,07 & 9,58 & 19,84 & 612,1 \\
\hline $45-60$ & $\mathrm{G}+\mathrm{E}$ & 0 & 1,83 & 1,73 & 4,30 & 0.38 & 0.27 & 6.43 & 0,12 & 7,85 & 7,20 & 11,28 & 522,8 \\
\hline $45-60$ & $\mathrm{P}$ & 0,13 & 2,73 & 14,30 & 4,93 & 0,43 & 0,30 & 20.48 & 0,15 & 22,11 & 21,36 & 33,90 & 582,2 \\
\hline $45-60$ & $G+P$ & 0,15 & 2.39 & 1,98 & 5,80 & 0.66 & 0,29 & 9,11 & 0,08 & 10,31 & 10,14 & 13,22 & 501,9 \\
\hline $45-60$ & $T$ & 0,03 & 2,39 & 4.08 & 4,32 & 0,38 & 0.25 & 9.36 & 0,67 & 10,80 & 10,66 & 16,68 & 526,3 \\
\hline $60-90$ & G & 0 & 1,33 & 13,00 & 3.88 & 0.77 & 0,57 & 16.44 & 0,11 & 18,19 & 17,89 & 20,08 & 632,8 \\
\hline $60-90$ & E & 0,18 & 3,88 & 1,51 & 5,12 & 0.24 & 0,16 & 9.36 & 0,12 & 10,68 & 9,87 & 20,93 & 611.8 \\
\hline $60-90$ & $G+E$ & 0,05 & 1,91 & 1,68 & 5,07 & 0.34 & 0.25 & 7.11 & 0,42 & 8.70 & 8,12 & 13,09 & 515,3 \\
\hline $60-90$ & $\mathrm{P}$ & 0,08 & 2,13 & 25.60 & 3,89 & 0.63 & 0,46 & 30.01 & 0,07 & 31,64 & 31.16 & 40.65 & 704.9 \\
\hline $60-90$ & $\mathrm{G}+\mathrm{P}$ & 0.05 & 2,11 & 2.81 & 5,88 & 0.49 & 0,31 & 9.61 & 0,24 & 10,85 & 10,64 & 15,19 & 520.5 \\
\hline $60-90$ & $T$ & 0 & 1,81 & 6.80 & 4.77 & 0.36 & 0,24 & 12.67 & 0.18 & 13,38 & 13.44 & 23,13 & 565.4 \\
\hline
\end{tabular}

${ }^{(1)} \mathrm{G}=$ Gesso; $\mathrm{E}=$ Esterco de curral; $\mathrm{P}=$ Palha de carnauba: $\mathrm{T}=$ testemunha

${ }^{(2)} \mathrm{RAS}=$ Relação de adsorção de sódio $\left\{\mathrm{RAS}=\mathrm{Na} \cdot[(\mathrm{Ca}+\mathrm{Mg}) / 2]^{-1 / 2}\right\}$.

${ }^{(3)}$ Corresponde a umidade do solo saturado. 
conforme Braga (1983). O comportamento da produção vem, validar as respostas analíticas dos parâmetros de química de solo. Com $1 / 3$ da necessidade de gesso foi obtido o mesmo nível de rendimento de algodão que com $2 / 3$ e recomendação integral. $\mathrm{Na}$ figura 8a observa-se que a produção de algodão aumentou com a primeira fração de gesso e permaneceu em platô para todas as frações testadas, com rendimento médio aproximado de $1.800 \mathrm{~kg} \cdot \mathrm{ha}^{-1}$. Trabalhos com outras culturas também enfatizam a diminuição da necessidade de gesso para menos da metade do recomendado para correção de solos sódicos, satisfazendo os requerimentos para altos rendimentos (Shahi et al, 1978 e Lucena, 1986).

No cultivo aos 54 meses da gessagem já não se constatou efeito do condicionador na produção de arroz sendo obtidas altas produtividades independente da dose de gesso (Figura 8b).

No ensaio de métodos de correção do solo os resultados de produção de algodão há um ano da aplicação dos materiais e da subsolagem só responderam ao efeito dos condicionadores, com produção média proporcionada pelo gesso mais esterco superior a obtida na testemunha $(P<0,05)$ e não diferindo dos demais tratamentos (Tabela 12).

Após dois anos da aplicação dos condicionadores e com subsolagem repetida, o efeito dessa prática proporcionou a obtenção de maior produtividade de algodão, pelo teste - $\mathrm{F}(\mathrm{P}<0,05)$. Nessa ocasião o efeito residual dos condicionadores embora favorecendo acréscimo na produção de até $1.000 \mathrm{~kg} \cdot \mathrm{ha}^{-1}$ em relação a testemunha, as diferenças não foram significativas, pelo mesmo teste estatístico.

O preparo do solo associado a subsolagem, gessagem com $1 / 3$ da dose recomendada e/ou adubação orgânica com esterco de curral quando disponível (20 $M g \cdot \mathrm{ha}^{-1}$ ), são práticas de baixo custo e apresentam bom potencial de resposta para o algodoeiro irrigado por aspersão, em solo salino-sódico. O custo do gesso ou do subproduto da industria de adubos fosfatados (gesso agrícola) que é até mais eficiente (Keren \& Shainberg, 1981) se resume apenas ao transporte (Petrofértil espera que o uso do gesso..., 1992). A subsolagem requer apenas 1,5 a 2 horas por hectare de operação 
tratorizada e deve ser realizada antes de cada cultivo, por ser de efeito temporário (Ayers \& Westcot, 1991 e Gheyi \& Medeiros, 1992).
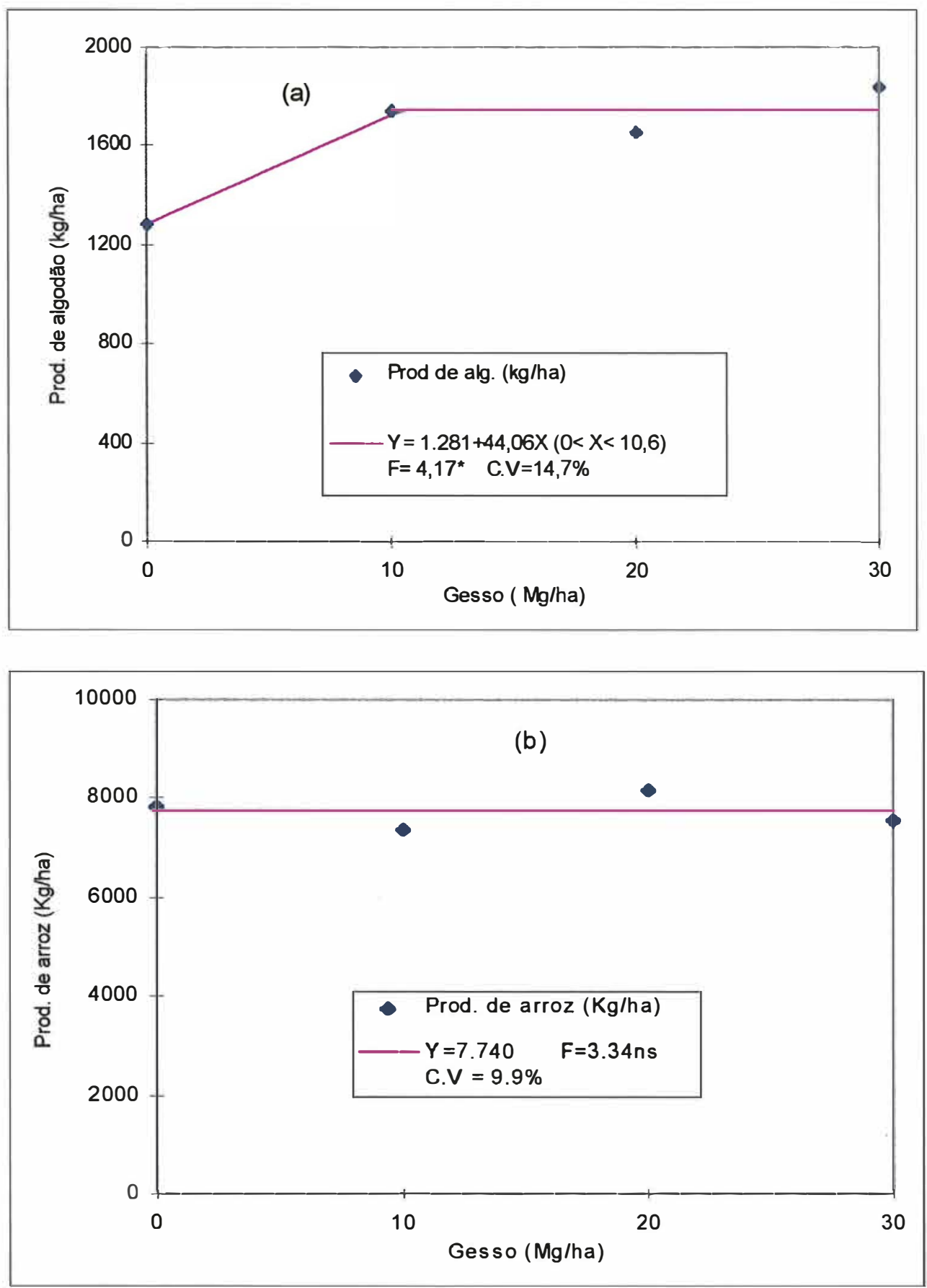

Figura 8 - Efeito de doses de gesso na produção de culturas, em duas épocas após a aplicação: após três meses, algodão CNPA-precoce 1 irrigado por aspersão(a) e após 54 meses, arroz metica-1 irrigado por inundação (b). 
Tabela 12 - Rendimentos de arroz e algodão em diferentes épocas após a aplicação dos condicionadores e resumo das análises estatísticas. Ensaio de métodos de correção, médias de 4 repetições em solo sem e com subsolagem.

\begin{tabular}{|c|c|c|c|c|c|c|c|c|}
\hline \multirow{3}{*}{$\begin{array}{l}\text { Condicio- } \\
\text { nador }^{1}\end{array}$} & \multicolumn{8}{|c|}{ Produção de culturas/ano/Subsolagem - $\left(\mathrm{kg} \cdot \mathrm{ha}^{-1}\right)$} \\
\hline & \multicolumn{2}{|c|}{ Arroz - 1990} & \multicolumn{2}{|c|}{ Algodão - 1991} & \multicolumn{2}{|c|}{ Algodão - 1992} & \multicolumn{2}{|c|}{ Arroz - 1993} \\
\hline & Sem & Com & Sem & Com & Sem & Com & Sem & Com \\
\hline G & 2.250 & 4.514 & 2.482 & 2.118 & 2.206 & 2.278 & 7.361 & 7.130 \\
\hline $\mathrm{E}$ & 3.965 & 4.507 & 1.818 & 2.187 & 2.040 & 2.999 & 7.407 & 7.639 \\
\hline $\mathrm{G}+\mathrm{E}$ & 3.708 & 3.170 & 2.878 & 2.050 & 2.391 & 2.451 & 7.639 & 7.963 \\
\hline $\mathrm{P}$ & 4.271 & 3.208 & 2.120 & 2.437 & 1.945 & 2.778 & 7.407 & 7.778 \\
\hline $\mathrm{G}+\mathrm{P}$ & 2.955 & 4.114 & 2.360 & 2.361 & 1.953 & 2.886 & 7.778 & 7.824 \\
\hline $\mathrm{T}$ & 3.003 & 3.569 & 1.786 & 1.666 & 1.827 & 2.008 & 7.595 & 7.963 \\
\hline Médias & 3.359 & 3.847 & 2.241 & 2.137 & 2.060 & 2.567 & 7.532 & 7.717 \\
\hline \multicolumn{9}{|l|}{ Valor $F^{2}$} \\
\hline Subs.(S) & \multicolumn{2}{|c|}{$1,78 \mathrm{~ns}$} & \multicolumn{2}{|c|}{$0,58 \mathrm{~ns}$} & \multicolumn{2}{|c|}{$6,76^{*}$} & \multicolumn{2}{|c|}{$0,33 \mathrm{~ns}$} \\
\hline Cond (C) & \multicolumn{2}{|c|}{$0,60 \mathrm{~ns}$} & \multicolumn{2}{|c|}{$2,70^{*}$} & $2,75 \mathrm{~ns}$ & $1,45 \mathrm{~ns}$ & \multicolumn{2}{|c|}{$0,31 \mathrm{~ns}$} \\
\hline$(\mathrm{S} \times \mathrm{C})$ & \multicolumn{2}{|c|}{$1,76 \mathrm{~ns}$} & \multicolumn{2}{|c|}{$1,80 \mathrm{~ns}$} & \multicolumn{2}{|c|}{$0,95 \mathrm{~ns}$} & \multicolumn{2}{|c|}{$0,09 \mathrm{~ns}$} \\
\hline HSD-5\% & \multicolumn{2}{|c|}{745} & \multicolumn{2}{|c|}{713} & 675 & 1.470 & \multicolumn{2}{|c|}{ 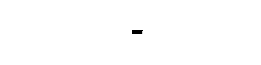 } \\
\hline C.V.(\%) & \multicolumn{2}{|c|}{35,2} & \multicolumn{2}{|c|}{21,5} & 14,2 & 24,9 & \multicolumn{2}{|c|}{14,6} \\
\hline
\end{tabular}

${ }^{1} \mathrm{G}=$ Gesso; $\mathrm{E}=$ Esterco de curral; $\mathrm{P}=$ Palha de carnaúba; $\mathrm{T}$ = testemunha

${ }^{2}$ Médias de tratamentos ou interações: ns $=$ não diferem entre si $(\mathrm{P}<0,05)$;

* diferem $(\mathrm{P}<0,05) ;{ }^{* *}$ diferem $(\mathrm{P}<0,01)$.

Com o arroz, na fase inicial de experimentação(1990), observou-se uma tendência para obtenção de melhores rendimentos com a prática da subsolagem, o que não se confirmou pelo teste - F $(\mathrm{P}<0,05)$. Em nenhum dos cultivos de arroz houve aumento de produção decorrente do uso de condicionadores (Tabela 12), pelo mesmo teste estatístico. O segundo cultivo de arroz apresentou mais do dobro do rendimento obtido no primeiro, evidenciando que a irrigação por aspersão, nesse tipo de solo, não satisfaz a necessidade hídrica da cultura, sendo mais conveniente irrigar por bacias de inundação. 
Em condição de cultivo inundado os rendimentos de arroz foram elevados independente do uso de condicionadores e foram equiparáveis em ambas as situações de preparo do solo. Os resultados com arroz inundado estão de pleno acordo com os conseguidos por Pereira et al (1985) e Gheyi et al. (1995), sendo facilmente entendidos pelas condições de salinidade e sodicidade, dominantes no período, cujos valores estão muito aquém do crítico: $\mathrm{C}_{\mathrm{es}}<3$ (Rhoades et al., 1992); PST $<55 \%$ na camada superficial (Abrol \& Bhumbla, 1979).

Em períodos anteriores à pesquisa buscava-se explicações para o não efeito do gesso e subsolagem na produção de arroz inundado, em solos sódicos. Atualmente, procura-se o inverso; se houve efeito na produção, quais foram as causas?.

Em pesquisas desenvolvidas na Índia, ao contrário desta, houve efeito favorável do gesso na produção de arroz (Abrol \& Bhumbla, 1979; Singh \& Singh, 1989 e Dubey \& Mondal, 1994). A causa do favorecimento do gesso está nas condições de solo extremamente adversas: pH acima de 10 e PST acima de $90 \%$. Os aumentos de produção no entanto se concentraram geralmente no primeiro ano pois, com o manejo do solo/água/cultura a situação foi amenizada e nos cultivos subsequentes o efeito desapareceu.

Em condições do Nordeste semi-árido do Brasil foram obtidos resultados opostos aos deste trabalho, com a subsolagem elevando a produtividade do arroz (Silva, 1978; Ferreyrah \& Coelho, 1986 e Costa et al, 1990). A suspeita nestes casos são direcionadas para a lâmina de irrigação que nem sempre é mantida, ocasionando alternâncias de $C . E_{\text {es }}$ baixas e altas, pelo movimento ascendente e descendente de sais no perfil, mais acentuado em áreas não subsoladas. Numa das referências é citada uma reaplicação semanal da lâmina de água e, nos registros de C. $E_{\text {es }}$, constam valores da ordem da salinidade limiar do arroz, ao final do experimento em área não subsolada.

Em princípio concorda-se com Oliveira (1988) quando afirma que o cultivo de plantas tolerantes em solo salino-sódicos parece ser a solução mais viável. A afirmativa no entanto carece de um adendo; só isso não é suficiente, só isso não satisfaz. Após quase 5 anos de insistência no raciocínio desse autor, empresas instaladas no vale 
do Açu terminaram desistindo por não suportarem os prejuízos, não disporem de tecnologia ou considerá-las antieconômicas.

\subsection{Comentários e observações}

Sem dúvida, os solos afetados por sais mais problemáticos são os aluviais, por algumas razões: existe uma intensa variabilidade de caráter tridimensional tanto fisica como química, fazendo com que esses solos não tenham identidade própria; o perfil dos mesmos não segue uma seqüência lógica de horizontes, é constituído de camadas; salinidade e/ou sodicidade não são parâmetros de caracterização ou identificação desses solos mas, características que quando presentes atingem diversas camadas, necessitando portanto, para diagnóstico, de levantamento detalhado.

A composição granulométrica dos solos aluvionais guarda uma estreita relação com a sua mineralogia e, esta é que determina ou condiciona a intensidade ou grau de afetação por sais, especialmente quando predomina argilas do grupo das esmectitas. O problema crucial das áreas de aluviões não é o sodicidade mas sim, o próprio solo com textura franco siltosa a argilosa que dificulta operações mecanizadas quando umedecido ou bastante seco.

Alguns tabus precisam ser quebrados quanto a solos salino-sódicos e as interpretações postas no seu devido lugar:

O primeiro é quanto a origem do problema que nos perímetros irrigados do Nordeste situados em solos aluvionais é atribuída a salinização secundária; na maioria dos casos é de origem primária. O homem leva a culpa por sempre botar o carro na frente dos bois; não faz um diagnóstico inicial do grau de afetação de sais nessas áreas e ao intensificar o seu uso, através da irrigação, percebe o problema e nela põe a culpa.

A experiência tem mostrado que em solos aluvionais, nas condições nordestinas, três requisitos básicos estando presentes não ocorrem problemas permanentes por sais: 1 - solo arenoso (areia $>65 \%$ em todo o perfil), lençol freático com flutuação abaixo de $2 \mathrm{~m}$ de profundidade e uso de água de qualidade compatível.

O segundo é quanto aos altos requerimentos de gesso para correção da sodicidade que em algumas situações até assustam. É preciso se conscientizar de que 
essas estimativas são meros indicadores para substituição do sódio a um nível desejado, totalmente por cálcio proveniente de gesso. Esquece-se que a composição mineralógica do solo pode contribuir para a redução e que pelas características químicas do sódio; valência e raio iônico hidratado, ele é facilmente trocado, deslocando-se no perfil do solo na primeira oportunidade, sob condições de campo favoráveis. Com um manejo adequado de solo/água/planta, as necessidades de gesso poderão ser reduzidas a 20 ou $30 \%$ da recomendação ou, até mesmo não serem empregadas, se o solo tem bastante cálcio.

Obras de engenharia de drenagem da área total, acima de 10.000 ha, como a do Baixo Açu, seriam tão onerosas que assustaria qualquer govemante e, os seus efeitos e a relação custo/benefício deixam muitas dúvidas, já que o solo não muda de composição textural.

Pergunta-se então, por que trombar contra a natureza se o ideal consiste em usufruir do que ela permite? Entretanto, nem tudo é prejudicial pois, enquanto algumas regiões do país procura impermeabilizar o solo para economia de água na produção de arroz irrigado, o Nordeste dispõe de muitas áreas semi-impermeáveis naturalmente e, Estado como o Rio Grande do Norte continua importando $90 \%$ do arroz que consome, embora, apresente um potencial de rendimento superior a $10.000 \mathrm{~kg} . \mathrm{ha}^{-1}$ de arroz, nos referidos solos, com pouco investimento em tecnologia.

Algumas barreiras do tradicionalismo limitam a exploração racional desta áreas. Elas nunca poderão ser manejadas como as de tabuleiro pois, são completamente diferentes. O sucesso do empreendimento depende de operações integradas e seqüenciais que compreendem a escolha da cultura, preparo do solo, sistema de irrigação, mecanização, adubação e manutenção da lavoura, todos operacionalisados em sistemas que se adequem à real situação. No cultivo do arroz inundado, basta preparar as marachas, corrigir os desvios de fertilidade, plantar e irrigar. Ninguém vai fazer subsolagem e gessagem simplesmente por estar na moda ou parecer bonito! 


\section{CONCLUSÕES}

A incorporação de $1 / 3$ da necessidade de gesso para a correção do solo produziu efeito semelhante a $2 / 3$ e a recomendação integral, na redução da salinidade e da sodicidade, no aumento do cálcio trocável e na produção de algodão.

A salinidade do solo medida aos nove meses da gessagem foi maior com a aplicação do condicionador e decresceu nos periodos posteriores.

$\mathrm{O}$ efeito do gesso nos parâmetros de química do solo até 12 meses, ficou restrito à camada de aplicação. Aos 24-30 meses se manifestava até a profundidade de 30-60 cm. Aos 40 meses não foi observado efeito do gesso na PST e aos 60 meses em solo com preparo convencional e pouca intensidade de uso, favoreceu para uma menor salinidade em profundidades abaixo de $60 \mathrm{~cm}$, em condições inundadas.

A gessagem contribuiu para diminuição da alcalinidade do solo. A diminuição do pH guarda estreita relação com a redução do sódio trocável.

O gesso foi mais eficiente na redução da PST do solo que os condicionadores orgânicos. A combinação com esterco de curral (até $20 \mathrm{Mg}^{-h a^{-1}}$ base seca) foi benéfica e proporcionou maior produção de algodão que na testemunha, um ano após a aplicação.

A palha de carnaúba exerceu um efeito danoso no solo, mantendo altas a salinidade e sodicidade e baixo o cálcio trocável. As maiores concentrações de sódio e cloro na solução do solo foram determinadas ao final do experimento na área com incorporação de palha de carnaúba.

A subsolagem proporcionou um efeito eficaz e persistente, com redução na PST do solo em todas as épocas avaliadas. Na irrigação por aspersão a subsolagem associada a gessagem acelerou a redução da PST. Quando combinada com irrigação por inundação amenizou a PST em todo o perfil do solo. 
O solo deixou de ser salino somente com a inundação para cultivo do arroz. Quando irrigado por aspersão a C.E $E_{\text {es }}$ permaneceu acima da salinidade limiar do arroz. Em cultivo inundado a cultura produziu mais do dobro que na condição anterior, seus rendimentos porém, independem do tipo de preparo do solo e do uso de condicionadores. 


\section{REFERÊNCIAS BIBLIOGRÁFICAS}

ABROL, I. P.; BHUMBLA, D. R. Crop responses to diferential gypsum applications in a highly sodic soil and tolerance of several crops to exchangeable sodium under field conditions. Soil Science, v.127, n.2, p.79-85, 1979.

ABROL, I. P.; DAHIYA, I. S.; BHUMBLA, D. R. On the method of determining gypsum requirement of soils. Soil Science, v.120, n.1, p.30-45, 1975.

AGASSI, M.; MORIN, J.; SHAINBERG, I. Laboratory studies of infiltration and runoff control in semi-arid soils in Israel. Geoderma, v.28, p.345-56, 1982.

ALMEIDA, M.T. Torta de filtro e vinhaça como alternativa na recuperação de um solo salino-sódico. Viçosa, 1994. 52p. Dissertação (M.S.) - Universidade Federal de Viçosa.

ARMSTRONG, A.S.B.; TANTON, T.W. Gypsum applications to aggregated salinesodic clay topsoils. Journal of Soil Science, v. 43, p.249-60,1992.

AYERS, R. S.; WESTCOT, D. W. Water quality for agriculture. Rome:FAO, 1976. 97p. (FAO. Irrigation and Drainage, 29).

AYERS, R. S.; WESTCOT, D. W. A qualidade da água na agricultura. Campina Grande:UFPB, 1991. 218p. (FAO. Irrigação e Drenagem, 29). 
BENNETT, O. L.; ASHLEY, D.A.; DOSS, B.D. Methods of reducing soil crusting to increase cotton seedling emergence. Agronomy Journal, v.56, p.162-5, 1964.

BRAGA, J. M. Avaliação da fertilidade do solo: ensaios de campo. Viçosa: Universidade Federal de Viçosa, 1983. $101 \mathrm{p}$.

BRASIL. Superintendência do Desenvolvimento do Nordeste. DRN. Plano de aproveitamento integrado dos recursos hídricos do Nordeste do Brasil Fase I. Recife: PLIRHINE, 1978. 3v.

CAVALCANTE, L.F. Efeito do fosfogesso em solos salinizados da Paraiba cultivados com feijão vigna. Piracicaba, 1984. 94p. Tese (Doutorado) - Escola Superior de Agricultura "Luiz de Queiroz", Universidade de São Paulo.

CORDEIRO, G. G.; BARRETO, A. N.; CARVAJAL, A. C. N. Levantamento das condições de salinidade e sodicidade do Projeto de irrigação de São Gonçalo. $\left(2^{\mathrm{a}}\right.$ parte). Petrolina: EMBRAPA/CPATSA, 1988. 57p. (EMBRAPA/CPATSA. Documentos, 54).

COSTA, R.N.T.; SAUNDERS, L.C.U.; HERNANDEZ, F.F.F.; COSTA, J.O. Avaliação de um sistema de drenagem superficial em um solo sódico no Vale do Curu - CE. Irrigação e Tecnologia Moderna, n.40, p.21-6, mar. 1990.

DUBEY, S.K.; MONDAL, R.C. Effect of amendments and saline irrigation water on soil properties and yields of rice and wheat in a highly sodic soil. Journal of Agricultural Science, v.122, p.351-7, 1994.

ESTADOS UNIDOS. Department of Agriculture. Keys to soil taxonomy. 4.ed. Washington: USDA, 1990. 422p. (USDA. SMSS Technical Monograph, 6). 
FARIAS, M. E. Comportamento ecofisiológico de Blutaparon portulacoides (St. Hil) Mears 1982 (Amaranthaceae) cultivada em diferentes concentrações de $\mathrm{NaCl}$. Porto Alegre, 1985. 96p. Dissertação (Mestrado) - Universidade Federal do Rio Grande do Sul.

FERREYRAH, F. F.; COELHO, M. A. Efeito de dose de gesso e subsolagem na produtividade de arroz em solo sódico. Revista Brasileira de Ciência do Solo, v.10, n.2, p.157-61, 1986.

FREIRE, J. R. J. Microbiologia do solo. Porto Alegre: UFRGS, Faculdade de Agronomia, 1975. 234p.

FREITAS, J. A. D.; COELhO, M. A.; FERREIRAH, F. F. Efeito de corretivos químicos e materiais orgânicos no movimento da água e estrutura de solo salinosódico. Revista Brasileira de Ciência do Solo, v. 8, n.3, p.261-4, 1984.

FRENKEL, H.; HADAS, A. Effects of tillage and gypsum incorporation on rain runoff and crust strength in field soils irrigated with saline-sodic water. Soil Science Society of America Journal, v.45, p.156-8, 1981.

GHASSEMI, F.; JAKEMAN, A.J.; NIX, H.A. Salinisation of land and water resources: human causes extent, management and case studies. Sydney: Universidade of New South Wales Press., 1995. p.112.

GHEYI, H. R.; MEDEIROS, J. F. Prevenção, manejo e recuperação dos solos salino e sódico. In: CONGRESSO NACIONAL DE IRRIGAÇÃO E DRENAGEM, 9., . Natal. 1991. Natal: ABID, 1991. p.67. 
GHEYI, H.R.; AZEVEDO, N.C. de; BATISTA, M.A.F.; SANTOS, J.G.R. dos,. Comparação de métodos na recuperação de solo salino-sódico. Revista Brasileira de Ciência do Solo, v. 19, n.2, p.173-8, 1995.

GOES, C.S. Problemas de salinidade e drenagem em projetos de irrigação do Nordeste e a ação da pesquisa com vistas a seu equacionamento. Recife: MINTER/SUDENE, 1978. 20p. (Relatório de Resultados).

GUPTA, B.R.; BAJPAI, P.D. Effect of some inorganic ameliorants on reclamation and phosphorus availability in salt-affected soils. Indian Journal of Agriculture Research, v.11, n.2, p.87-103, 1977.

ILYAS, M.; MILLER, R.W.; OWRESHI, R.H. Hydraulic conductivity of saline-sodic soil after gypsum application and cropping. Soil Science Society of America Journal, v.57, p.1580-5, 1993.

KEREN, R.; SHAINBERG, I. Effect of dissolution rate on the efficiency of a sodic soil Soil Science Society of America Journal, v. 45, p.103-7, 1981.

LOVEDAY, J. Recognition of gypsum-responsive soils. Australian Journal of Soil Research, v. 25, v.87-96, 1974.

LOVEDAY, J. Sodic soils and their reclamation - a review. In: Proceedings of the INTERNATIONAL SYMPOSIUM ON THE RECLAMATION OF SALTAFFECTED SOILS, Jinan, 1985. Proceedings., China: Beijing Agricultural University, 1985. pt. 2, p 410-29. 
LUCENA, E.R. Efeito da aplicação do fosfogesso em um solo salino-sódico. Piracicaba, 1986. 94p. Dissertação (Mestrado) - Escola Superior de Agricultura "Luiz de Queiroz", Universidade de São Paulo.

McINTYRE, D.S. Exchangeable sodium, subplasticity and hydraulic conductivity of some Australian soils. Australian Journal of Soil Research, v.17, p.115-20, 1979.

MELO, F.B.; COELHO, M.A.; FERREYRAH, F.F. Efeitos do gesso e da concentração salina da água na condutibilidade hidráulica do solo. Revista Brasileira de Ciência do Solo, v.12, n.2, p.89-92, 1988.

OLIVEIRA, J.B.; JACOMINE, A.K.T.; CAMARGO, M.N. Classes gerais de solos do Brasil: guia auxiliar para seu reconhecimento. Jaboticabal:FUNEP, 1992. 201p.

OLIVEIRA, M. Os solos e o ambiente agrícola no sistema Piranhas-Açu. Mossoró: ESAM/FGD, 1988. 314p. (Coleção Mossoroense, 380).

PEREIRA, F.A.M. Solos afetados por sais: caracterização, problemas e manejo. Caicó: EMBRAPA/EMPARN, 1982. 17p.

PEREIRA, J. R.; VALDIVIESO, C. R.; CORDEIRO, G.G. Recuperação de solos afetados por sódio através do uso de gesso. In: SEMINÁRIO SOBRE USO DO FOSFOGESSO NA AGRICUlTURA, Brasilia, 1985. Brasilia, 1985. p. 85-105.

PETROFÉRTIL espera que o uso de gesso agrícola estimule consumo de fertilizantes. Petrofértil Rural, Rio de Janeiro, v. 11, p. 5-7, abr./jun. 1992.

PIZARRO, F. Drenaje agricola y recuperacion de suelos salinos. Madri:Editorial Agricola Española, 1985. 542p. 
PONNAMPERUMA, F.N. Dynamic aspect of flooded soils and the nutrition of the rice plant. In: The mineral nutrition of the rice plant. Maryland: J. Hopkins, 1964. p.215-328.

PUTTASWAMYGOWDA, B.S.; PRATT, P.P. Effects of straw, calcium chloride, and submergence on a sodic soil. Soil Science Society of America Journal, v.37, n.2, p.208-12, 1973.

RASMUSSEN, W.W.; McNEAL, B.L. Predicting optimum depth of profile modification by deep plowing for improving saline-sodic soils. Soil Science of America Proceedings, v.37, p.432-7, 1973.

RASMUSSEN, W.W.; MOORE, D.P.; ALBAN, L.A. Improvement of a solonetzico (slick spot) soil by deep plowing, sub-soiling, and amendements. Soil Science Society of America Proceedings, v.36, p. 137-42, 1972.

RENGASAMY, P.A.; OLSSON, K.A. Irrigation and sodicity. Australian Journal of Soil Research, v.31, n.6, p.821-38, 1993.

RHOADES, J.D.; KANDIAH, A.; MASHAI, A.M. The use of saline waters for crop production. Rome: FAO, 1992. 133p. (FAO. Irrigation and Drainage, 48).

RICHARDS, L.A. Diagnostico y rehabilitacion de suelos salinos y sodicos. México: Ed. Limusa, 1974. 172p.

SANTOS, R.V. Correção de um solo salino-sódico e absorção de nutrientes pelo feijão macassar (Vigna unguiculata L. Walp.). Piracicaba, 1995. 117p. Tese (Doutorado) - Escola Superior de Agricultura "Luiz de Queiroz", Universidade de São Paulo. 
SHAHI, H.N.; MASKINA, M.S.; GILL, P.S. Effect of different levels of gypsum application on soil characteristics and growth and yield of rice (Oryza sativa, L). Short communication. Plant and Soil, v. 49, p.437-42, 1978.

SHAINBERG, I.; LETEY, J. Response of soils to sodic and saline conditions. Hilgardia, v.52, n.2, p.1-57, 1984.

SHAINBERG, I.; RHOADES, J.D.; PRATHER, R.J. Effect of low electrolyte concentration on clay dispersion and hydraulic conductivity of a sodic soils. Soil Science Society of America Journal, v.45, p.273-7, 1981.

SHAINBERG, I.; SUMNER, M.E.; MILLER, W.P.: PAVAN, M.A.; FEY, M.V. Use of gypsum on soils: a review. Advances in Soil Science, v.9, p.1-111, 1989.

SILVA, A.G. O domínio do processo de trabalho na agricultura irrigada do Nordeste: a persistência da parceria. Campinas, 1992. 252p. Tese (Doutorado). Instituto de Economia. Universidade Estadual de Campinas.

SILVA, M.J. Efeito de métodos de recuperação em solo com problemas de sais no projeto de irrigação de São Gonçalo-PB. Viçosa. 1978. 54p. Dissertação.(M.S.) Universidade Federal de Viçosa.

SINGH, G.; ABROL, J.P.; CHEEMA, S.S. Effects of gypsum applications on mesquite (Prosopis juliflora) and soil properties in an abandoned sodic soil. Forest Ecological Management, v.29, p.1-14, 1989.

SINGH, M.V.; SINGH, K.N. Reclamation techniques for improvement of sodic soils and crop yield. Indian Journal of Agriculture Science, v.59, n.8, p.495-500, 1989. 
SO, H.B.; AYLMORE, L.A.G. How do sodic soils behave? The effects of sodicity on soil physical behaviour. Australian Journal of Soil Research, v.31, n.6, p.761-78, 1993.

SRINIVASAN, V.S.; BARROS, M.G.; FIGUEIREDO, E.E. Um estudo da viabilidade do uso dos pequenos açudes para irrigação pelo pequeno produtor. In: CONGRESSO NACIONAL DE IRRIGAÇÃO E DRENAGEM, 7., Brasília, 1986. Anais. Brasilia:ABID, 1986. p.731-48.

SUMNER, M.E. Uso atual do gesso no mundo em solos ácidos. In: SEMINÁRIO SOBRE O USO DO GESSO NA AGRICULTURA, São Paulo, 1992. Anais. São Paulo:IBRAFOS, 1992. p.1-40

SUMNER, M.E. Sodic soils: new perspectives. Australian Journal of Soil Research, v.31, n.6, p.683-750, 1993

SZABOLCS, I. Agronomical and ecological impact of irrigations on soil and water salinity. Advances in Soil Science, v.4, p.189-218, 1986.

SZABOLCS, I. Salt-affected soils. Flórida:Library of Congress, 1989. 274p.

VITTI, G.C. Avaliação e interpretação do enxofre no solo e na planta. Jaboticabal: UNESP/FUNEP, 1989. 37p.

YAGODIN, B.A. Agricultural chemistry. Moscow:Mir Publishers, 1984. 375p.

YAP-SALINAS, L.H.; BRITO, R.A.L. Impactos fisicos prováveis e considerações sobre uma política de manejo para o projeto de irrigação do baixo Açu. In: SIMPÓSIO BRASILEIRO SOBRE O TRÓPICO SEMI-ÁRIDO, 1., Olinda, 1982. 


\section{APÊNDICES}


APÊNDICE 1 - Condutividade Elétrica no Extrato Saturado do Solo (C.E $\left.\mathrm{E}_{\mathrm{es}}\right)$ sob efeito de doses de gesso, em duas épocas após a aplicação e resumo das análises estatísticas. Ensaio de doses de gesso, médias de 4 repetições.

\begin{tabular}{|c|c|c|c|}
\hline \multirow{2}{*}{$\begin{array}{l}\text { Profundidade } \\
\text { Solo }(\mathrm{cm})\end{array}$} & \multirow{2}{*}{ 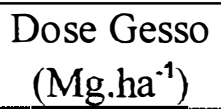 } & \multicolumn{2}{|c|}{ C.E es $\left._{\text {(dS.m }}{ }^{-1}\right) /$ Ėpoca avaliação - meses } \\
\hline & & 30 & 60 \\
\hline $0-30$ & 0 & 3,21 & 1,38 \\
\hline $0-30$ & 10 & 2,21 & 1,35 \\
\hline $0-30$ & 20 & 2,42 & 0,89 \\
\hline $0-30$ & 30 & 3,12 & 1,13 \\
\hline $30-60$ & 0 & 5,01 & 1,46 \\
\hline $30-60$ & 10 & 3,33 & 1,33 \\
\hline $30-60$ & 20 & 2,57 & 0,95 \\
\hline $30-60$ & 30 & 3,88 & 1,17 \\
\hline $60-90$ & 0 & 5,83 & 3,37 \\
\hline $60-90$ & 10 & 4,75 & 2,03 \\
\hline $60-90$ & 20 & 3,43 & 1,19 \\
\hline $60-90$ & 30 & 4,42 & 1,32 \\
\hline $90-120$ & 0 & 5,68 & 5,25 \\
\hline $90-120$ & 10 & 5,53 & 3,11 \\
\hline $90-120$ & 20 & 4,18 & 1,33 \\
\hline $90-120$ & 30 & 4,79 & 1,84 \\
\hline \multicolumn{2}{|c|}{ Valor-F (Gesso) ${ }^{1}$} & $2,26 \mathrm{~ns}$ & $7,4 \overline{7 * *}$ \\
\hline \multicolumn{2}{|c|}{ Valor-F (Profundidade) } & $23,78^{* *}$ & $44,84^{* *}$ \\
\hline \multicolumn{2}{|c|}{ Valor-F (Gesso x Profundidade) } & $1,33 \mathrm{~ns}$ & $10,91^{* *}$ \\
\hline \multicolumn{2}{|c|}{ H.S.D. 5\% (Gesso. x Prof.) } & - & 1,34 \\
\hline \multicolumn{2}{|c|}{ C.V. Gesso (\%) } & 48,4 & 61,1 \\
\hline \multicolumn{2}{|c|}{ C.V.Prof. $(\%)$} & 20,22 & 23,75 \\
\hline
\end{tabular}

** Existe diferença entre médias de tratamentos ou interações $(\mathrm{P}<0,05) ; \mathrm{ns}=$ médias não diferem entre si $(\mathrm{P}<0,05)$ 
APÊNDICE 2 - Condutividade Elétrica no Extrato Saturado de camadas do solo

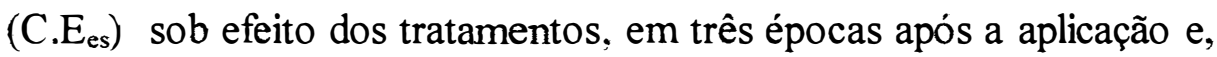
resumo das análises estatísticas. Ensaio de métodos de correção, médias de 4 repetições.

\begin{tabular}{|c|c|c|c|c|c|c|c|}
\hline \multirow{3}{*}{$\begin{array}{l}\text { Prof. } \\
\text { Solo } \\
\text { (cm) }\end{array}$} & \multirow{3}{*}{$\begin{array}{l}\text { Tratamento }{ }^{1} \\
\text { Condicionador }\end{array}$} & \multicolumn{6}{|c|}{ C.E es $\left(\mathrm{dS} . \mathrm{m}^{-1}\right) /$ Época/Subsolagem } \\
\hline & & \multicolumn{2}{|c|}{9 meses } & \multicolumn{2}{|c|}{24 meses } & \multicolumn{2}{|c|}{40 meses } \\
\hline & & Sem & Com & Sem & Com & Sem & Com \\
\hline $0-15$ & $\mathrm{G}$ & 6,88 & 5,99 & 4,46 & 4,56 & 1,96 & 1,59 \\
\hline $0-15$ & E & 4,01 & 3,43 & 3,23 & 2,78 & 2,02 & 1,58 \\
\hline $0-15$ & $\mathrm{G}+\mathrm{E}$ & 7,05 & 5,56 & 4,60 & 5,88 & 1,64 & 1,35 \\
\hline $0-15$ & $\mathrm{P}$ & 4,11 & 3,24 & 3,70 & 3,72 & 2,31 & 2,12 \\
\hline $0-15$ & $\mathrm{G}+\mathrm{P}$ & 6,26 & 4,61 & 3,25 & 3,84 & 1,48 & 1,09 \\
\hline $0-15$ & $\mathrm{~T}$ & 3,77 & 4,37 & 4,18 & 5,26 & 2,10 & 1,36 \\
\hline $15-30$ & G & 5,61 & 4,16 & 4,71 & 4,94 & 2,55 & 1,71 \\
\hline $15-30$ & E & 3,46 & 2,82 & 4,74 & 3,60 & 2,15 & 1,16 \\
\hline $15-30$ & $\mathrm{G}+\mathrm{E}$ & 4,03 & 4,84 & 5,80 & 6,04 & 1,57 & 1,15 \\
\hline $15-30$ & $\mathrm{P}$ & 3.88 & 3,55 & 4,19 & 4,03 & 1,92 & 2,20 \\
\hline $15-30$ & $\mathrm{G}+\mathrm{P}$ & 4,66 & 3,76 & 3,55 & 3,74 & 1,80 & 1,25 \\
\hline $15-30$ & $\mathrm{~T}$ & 3,52 & 4,64 & 5,43 & 4,94 & 1,91 & 0,74 \\
\hline $30-45$ & G & 4,21 & 3,97 & 3,79 & 5,75 & 1,87 & 1,23 \\
\hline $30-45$ & $\mathrm{E}$ & 3,69 & 4,89 & 5,42 & 4,12 & 2,37 & 1,01 \\
\hline $30-45$ & $\mathrm{G}+\mathrm{E}$ & 3,84 & 3,63 & 6,22 & 5,66 & 1,66 & 0,87 \\
\hline $30-45$ & $\mathrm{P}$ & 4,25 & 3,66 & 3,97 & 4,51 & 2,71 & 2,00 \\
\hline $30-45$ & $\mathrm{G}+\mathrm{P}$ & 4,50 & 3,39 & 4,37 & 3,96 & 1,70 & 1,13 \\
\hline $30-45$ & $\mathrm{~T}$ & 4,29 & 5,72 & 5,40 & 5,68 & 1,63 & 1,03 \\
\hline $45-60$ & G & 4,86 & 3,44 & 5,33 & 5,03 & 1,94 & 1,46 \\
\hline $45-60$ & E & 4,28 & 5,85 & 5,19 & 4,29 & 2,10 & 1,06 \\
\hline $45-60$ & $\mathrm{G}+\mathrm{E}$ & 4,27 & 3,34 & 5,34 & 6,06 & 1,16 & 0,94 \\
\hline $45-60$ & $\mathrm{P}$ & 5,18 & 4,48 & 3,82 & 4,44 & 3,67 & 2,41 \\
\hline $45-60$ & $\mathrm{G}+\mathrm{P}$ & 4,15 & 2,98 & 3,87 & 4,13 & 2,40 & 1,10 \\
\hline $45-60$ & $\mathrm{~T}$ & 4,77 & 6,73 & 5,39 & 6,02 & 1,77 & 1,17 \\
\hline $60-90$ & G & 4,87 & 6,22 & 5,14 & 5,22 & 2,75 & 1,68 \\
\hline $60-90$ & E & 5,30 & 7,94 & 4,57 & 5,28 & 1,94 & 1,15 \\
\hline $60-90$ & $\mathrm{G}+\mathrm{E}$ & 5,67 & 3,83 & 5,16 & 6,37 & 1,45 & 0,90 \\
\hline $60-90$ & $\mathrm{P}$ & 4,79 & 6,59 & 4,71 & 4,88 & 4,87 & 3,87 \\
\hline $60-90$ & $\mathrm{G}+\mathrm{P}$ & 4,59 & 3,83 & 4,05 & 4,35 & 3,53 & 1,23 \\
\hline $60-90$ & $\mathrm{~T}$ & 4,98 & 8,54 & 4,89 & 6,46 & 2,79 & 1,47 \\
\hline \multicolumn{2}{|c|}{ Médias } & 4,66 & 4,67 & 4,61 & 4,85 & 2,19 & 1,43 \\
\hline \multicolumn{2}{|c|}{ Valor $\mathrm{F}^{2}$ Subsolagem $(\mathrm{S})$} & \multicolumn{2}{|c|}{$0,04 \mathrm{~ns}$} & \multicolumn{2}{|c|}{$1,39 \mathrm{~ns}$} & \multicolumn{2}{|c|}{$85,59 * *$} \\
\hline Valor $\mathrm{F}$ & & \multicolumn{2}{|c|}{$0,40 \mathrm{~ns}$} & \multirow{2}{*}{\multicolumn{2}{|c|}{$\begin{array}{c}9,39 * \\
717^{* *}\end{array}$}} & \multicolumn{2}{|c|}{$25,97 * *$} \\
\hline \multicolumn{2}{|c|}{ Valor F Profundidade $(\mathrm{P})$} & \multicolumn{2}{|c|}{$16,45 * *$} & & & \multicolumn{2}{|c|}{$11,37^{* *}$} \\
\hline & or $F(S \times C)$ & \multicolumn{2}{|c|}{$2,93 *$} & \multicolumn{2}{|c|}{$0,17 \mathrm{~ns}$} & \multicolumn{2}{|c|}{$0,15 \mathrm{~ns}$} \\
\hline & or F (S x P) & \multicolumn{2}{|c|}{$4,54 * *$} & \multicolumn{2}{|c|}{$1.20 \mathrm{~ns}$} & & \\
\hline & or F (C x P) & & & \multicolumn{2}{|c|}{$0.62 \mathrm{~ns}$} & & \\
\hline Valo & $\mathrm{F}(\mathrm{S} \times \mathrm{C} \times \mathrm{P})$ & & & & & & \\
\hline HSD-5 & $(\mathrm{C}$ den ro de $\mathrm{P})$ & 2,28 & 2,62 & - & - & 2,23 & 1,61 \\
\hline C.V. C & ndicionador (\%) & & & & & & \\
\hline C.V.P & ofundidade (\%) & & & & & & \\
\hline
\end{tabular}

${ }^{\mathrm{T}} \mathrm{G}=$ Gesso; $\mathrm{E}=$ Esterco de curral; $\mathrm{P}=$ Palha de camaúba; $\mathrm{T}=$ Testemunha

${ }^{2}$ Tratamentos ou interações: $n s=$ não diferem entre si $(\mathrm{P}<0,05):{ }^{*}$ diferem $(\mathrm{P}<0,05) ;{ }^{*}$ diferem $(\mathrm{P}<0,01)$ 
APÊNDICE 3 - Porcentagem de Saturação de Sódio Trocável no solo (PST) sob efeito de doses de gesso, em quatro épocas após a aplicação e resumo das análises estatísticas. Ensaio de doses de gesso, médias de 4 repetições.

\begin{tabular}{cccccc}
\hline Profundidade & Dose Gesso & \multicolumn{4}{c}{ (PST)/Época Avaliação (meses) $^{2}$} \\
\cline { 3 - 6 } Solo $(\mathrm{cm})$ & $\left(\mathrm{Mg.ha}^{-1}\right)$ & 6 & 12 & 30 & 60 \\
\hline $0-30$ & 0 & 27,50 & 33,36 & 24,28 & 20,01 \\
$0-30$ & 10 & 15,32 & 17,52 & 16,67 & 13,78 \\
$0-30$ & 20 & 22,07 & 14,11 & 16,99 & 7,95 \\
$0-30$ & 30 & 35,38 & 11,48 & 10,03 & 11,69 \\
$30-60$ & 0 & 50,60 & 46,33 & 48,98 & 45,91 \\
$30-60$ & 10 & 41,15 & 47,17 & 28,50 & 44,68 \\
$30-60$ & 20 & 56,27 & 51,62 & 29,25 & 27,60 \\
$30-60$ & 30 & 50,17 & 46,37 & 33,92 & 30,00 \\
$60-90$ & 0 & 66,15 & 51,18 & 52,66 & 52,94 \\
$60-90$ & 10 & 54,00 & 63,39 & 48,77 & 55,40 \\
$60-90$ & 20 & 67,45 & 60,51 & 53,37 & 49,84 \\
$60-90$ & 30 & 66,45 & 57,06 & 54,89 & 47,24 \\
$90-120$ & 0 & 58,12 & 51,81 & 51,55 & 52,43 \\
$90-120$ & 10 & 56,15 & 60,43 & 54,15 & 53,31 \\
$90-120$ & 20 & 62,80 & 58,81 & 56,78 & 53,76 \\
$90-120$ & 30 & 56,17 & 58,92 & 52,54 & 50,58 \\
\hline Valor-F (Gesso) & $0,95 \mathrm{~ns}$ & $0,14 \mathrm{~ns}$ & $0,63 \mathrm{~ns}$ & $0,47 \mathrm{~ns}$ \\
Valor-F (Profundidade) & $42,09^{* *}$ & $49,36^{* *}$ & $47,31^{* *}$ & $54,12^{* *}$ \\
Valor-F(Gesso x & $0,73 \mathrm{~ns}$ & $0,90 \mathrm{~ns}$ & $1,22 \mathrm{~ns}$ & $0,82 \mathrm{~ns}$ \\
Profundidade) & & & & - \\
H.S.D. 5\% (Gess. x Prof.) & - & - & - & - \\
C.V. Gesso (\%) & 41,75 & 36,75 & 84,86 & 64,18 \\
C.V. Prof. (\%) & 21.38 & 18,00 & 51,30 & 24,79 \\
\hline
\end{tabular}

$T_{* *}$ Existe diferença entre médias de tratamentos ou interações $(\mathrm{P}<0,05)$

${ }^{2}$ Determinações aos 6 meses calculadas com base em cátions extraíveis. 
APÊNDICE 4 - Porcentagem de Saturação de Sódio Trocável em camadas do Solo (PST) sob efeito dos tratamentos, em três épocas após a aplicação e resumo das análises estatísticas. Ensaio de métodos de correção, médias de 4 repetições.

\begin{tabular}{|c|c|c|c|c|c|c|c|}
\hline \multirow{3}{*}{$\begin{array}{l}\text { Prof. } \\
\text { Solo } \\
(\mathrm{cm})\end{array}$} & \multirow{3}{*}{$\begin{array}{l}\text { Tratamento }{ }^{\mathrm{I}} \\
\text { Condicionador }\end{array}$} & \multicolumn{6}{|c|}{ PST/Epoca/Subsolagem } \\
\hline & & \multicolumn{2}{|c|}{9 meses } & \multicolumn{2}{|c|}{24 meses } & \multicolumn{2}{|c|}{40 meses } \\
\hline & & Sem & Com & Sem & Com & Sem & Com \\
\hline $0-15$ & $\mathrm{G}$ & 14,33 & 9,70 & 6,55 & 6,65 & 9,09 & 14,67 \\
\hline $0-15$ & $\mathrm{E}$ & 31,72 & 13,81 & 26,83 & 14,18 & 14,44 & 11,62 \\
\hline $0-15$ & $\mathrm{G}+\mathrm{E}$ & 10,38 & 7,46 & 11,05 & 6,45 & 13,71 & 6,61 \\
\hline $0-15$ & $\mathrm{P}$ & 26,89 & 22,17 & 30,00 & 18,75 & 29,78 & 14,48 \\
\hline $0-15$ & $\mathrm{G}+\mathrm{P}$ & 12,90 & 12,73 & 10,05 & 6,33 & 15,62 & 7,29 \\
\hline $0-15$ & $\mathrm{~T}$ & 35,99 & 18,64 & 24,25 & 19,15 & 13,55 & 7,42 \\
\hline $15-30$ & G & 28,96 & 32,43 & 15,23 & 16,70 & 19,22 & 20,10 \\
\hline $15-30$ & $\mathrm{E}$ & 40,93 & 17,21 & 44,18 & 24,00 & 22,12 & 10,97 \\
\hline $15-30$ & $\mathrm{G}+\mathrm{E}$ & 36,37 & 19,29 & 28,70 & 24,00 & 23,39 & 5,35 \\
\hline $15-30$ & $\mathrm{P}$ & 39,69 & 36,76 & 46,25 & 26,00 & 36,92 & 25,99 \\
\hline $15-30$ & $\mathrm{G}+\mathrm{P}$ & 31,61 & 26,79 & 18,35 & 13,25 & 28,00 & 6,84 \\
\hline $15-30$ & $\mathrm{~T}$ & 37,45 & 37,29 & 39,85 & 33,93 & 27,19 & 15,61 \\
\hline $30-45$ & G & 51,24 & 42,68 & 44,15 & 37,35 & 41,32 & 27,19 \\
\hline $30-45$ & E & 45,63 & 26,87 & 57,40 & 32,55 & 33,30 & 28,52 \\
\hline $30-45$ & $\mathrm{G}+\mathrm{E}$ & 50,30 & 35,90 & 49,08 & 40,48 & 39,71 & 15,72 \\
\hline $30-45$ & $\mathrm{P}$ & 56,99 & 38,89 & 58,95 & 34,78 & 48,44 & 38,15 \\
\hline $30-45$ & $\mathrm{G}+\mathrm{P}$ & 49,81 & 35,47 & 39,18 & 26,60 & 43,61 & 21,85 \\
\hline $30-45$ & $\mathrm{~T}$ & 42,25 & 50,09 & 55,95 & 48,53 & 40,96 & 23,28 \\
\hline $45-60$ & G & 60,35 & 58,51 & 60,63 & 52,33 & 52,85 & 33,99 \\
\hline $45-60$ & $\mathrm{E}$ & 52,03 & 33,45 & 61,55 & 35,95 & 56,05 & 47,66 \\
\hline $45-60$ & $\mathrm{G}+\mathrm{E}$ & 58,78 & 44,13 & 59,60 & 48,18 & 55,79 & 27,96 \\
\hline $45-60$ & $\mathrm{P}$ & 64,65 & 46,88 & 64,05 & 42,28 & 58,57 & 47.43 \\
\hline $45-60$ & $\mathrm{G}+\mathrm{P}$ & 54,42 & 44,81 & 49,08 & 35,03 & 53,53 & 31,59 \\
\hline $45-60$ & $\mathrm{~T}$ & 58,50 & 56,01 & 57,73 & 56,78 & 54,77 & 38,34 \\
\hline $60-90$ & G & 60,48 & 56,23 & 63,48 & 56,25 & 57,21 & 38,85 \\
\hline $60-90$ & $\mathrm{E}$ & 51,32 & 32,00 & 58,30 & 38,53 & 58,17 & 53,22 \\
\hline $60-90$ & $\mathrm{G}+\mathrm{E}$ & 60,51 & 45,75 & 61,80 & 53,50 & 56,03 & 37,61 \\
\hline $60-90$ & $\mathrm{P}$ & 62,52 & 49,65 & 64,90 & 44,10 & 59,62 & 55,78 \\
\hline $60-90$ & $\mathrm{G}+\mathrm{P}$ & 60,06 & 45,35 & 53,80 & 46,38 & 55,69 & 34,01 \\
\hline \multirow[t]{2}{*}{$60-90$} & $\mathrm{~T}$ & 57,01 & 53,38 & 58,85 & 56,65 & 56,79 & 39,74 \\
\hline \multirow{2}{*}{\multicolumn{2}{|c|}{$\begin{array}{c}\text { Médias } \\
\text { Valor } F:^{2} \text { Subsol agem }(\mathrm{S})\end{array}$}} & 44,80 & 35,00 & 43,99 & 33,19 & 39,18 & 26,25 \\
\hline & & \multicolumn{2}{|c|}{$14,68^{*}$} & \multicolumn{2}{|c|}{$12,58^{*}$} & \multicolumn{2}{|c|}{$36,02 * *$} \\
\hline \multicolumn{2}{|c|}{ Valor F Condicionador (C) } & \multicolumn{2}{|c|}{$1,85 \mathrm{~ns}$} & \multicolumn{2}{|c|}{$2,12 \mathrm{~ns}$} & \multicolumn{2}{|c|}{$3,15 \mathrm{~ns}$} \\
\hline Valor $\mathrm{F}$ & undidade $(\mathrm{P})$ & \multicolumn{2}{|c|}{$151,2^{* *}$} & \multicolumn{2}{|c|}{$309 * *$} & \multicolumn{2}{|c|}{$192 * *$} \\
\hline & $(\mathrm{S} \times \mathrm{C})$ & \multicolumn{2}{|c|}{$1,65 \mathrm{~ns}$} & \multicolumn{2}{|c|}{$1,29 \mathrm{~ns}$} & \multicolumn{2}{|c|}{$0,84 \mathrm{~ns}$} \\
\hline & $(\mathrm{S} \times \mathrm{P})$ & \multicolumn{2}{|c|}{$0,6 \operatorname{lns}$} & \multicolumn{2}{|c|}{$2,82^{*}$} & & \\
\hline & $(\mathrm{C} \times \mathrm{P})$ & & & & & & \\
\hline Valo & $(x(x)$ & & & & & & \\
\hline HSD-5 & dentro de $\mathrm{P}$ ) & 19,37 & 22,79 & 18,50 & 27,60 & - & - \\
\hline C.V.C & ionador (\%) & & & & & & \\
\hline C.V.P & ndidade (\%) & & & & & & \\
\hline
\end{tabular}


APÊNDICE 5 - Cálcio Trocável no solo sob efeito de doses de gesso, em quatro épocas após a aplicação e resumo das análises estatísticas. Ensaio de doses de gesso, médias de 4 repetições.

\begin{tabular}{cccccc}
\hline $\begin{array}{c}\text { Profundidade } \\
\text { Solo } \\
(\mathrm{cm})\end{array}$ & $\begin{array}{c}\text { Doses } \\
\text { Gesso } \\
\left(\mathrm{Mg.ha}^{-1}\right)\end{array}$ & \multicolumn{5}{c}{ Cálcio Trocável $\left(\mathrm{cmol}_{\mathrm{c}} \cdot \mathrm{kg}^{-1}\right) /{\text { Época Avaliação (meses })^{2}}^{2}$} & 6 & 12 & 30 & 60 \\
\hline $0-30$ & 0 & 7,98 & 7,28 & 8,39 & 8,76 \\
$0-30$ & 10 & 10,28 & 9,93 & 11,80 & 10,47 \\
$0-30$ & 20 & 10,39 & 10,84 & 12,31 & 9,65 \\
$0-30$ & 30 & 8,26 & 12,02 & 12,31 & 10,55 \\
$30-60$ & 0 & 8,40 & 7,33 & 8,81 & 7,94 \\
$30-60$ & 10 & 8,78 & 7,74 & 12,19 & 8,44 \\
$30-60$ & 20 & 6,75 & 7,20 & 11,78 & 10,03 \\
$30-60$ & 30 & 7,43 & 7,44 & 10,50 & 8,67 \\
$60-90$ & 0 & 6,68 & 6,52 & 8,46 & 6,93 \\
$60-90$ & 10 & 7,23 & 5,09 & 9,07 & 7,19 \\
$60-90$ & 20 & 4,77 & 5,89 & 8,28 & 6,78 \\
$60-90$ & 30 & 5,71 & 6,73 & 8,03 & 6,77 \\
$90-120$ & 0 & 8,13 & 7,60 & 8,69 & 7,15 \\
$90-120$ & 10 & 7,99 & 7,40 & 8,35 & 7,75 \\
$90-120$ & 20 & 6,12 & 6,02 & 7,47 & 6,60 \\
$90-120$ & 30 & 6,05 & 6,44 & 9,04 & 7,07 \\
\hline Valor-F & (Gesso) & $2,47 \mathrm{~ns}$ & $0,35 \mathrm{~ns}$ & $1,03 \mathrm{~ns}$ & $0,16 \mathrm{~ns}$ \\
Valor-F (Profundidade) & $16,60^{* *}$ & $20,29^{* *}$ & $23,38^{* *}$ & $11,33^{* *}$ \\
Valor-F (Gesso x Prof.) & $1,91 \mathrm{~ns}$ & $2,85^{* *}$ & $3,56^{* *}$ & $0,64 \mathrm{~ns}$ \\
H.S.D. 5\% (Gess. x Prof.) & - & 3,54 & 3,71 & - \\
C.V. Gesso (\%) & 26,69 & 35,24 & 31,33 & 39,29 \\
C.V. Prof. (\%) & 17,00 & 18,70 & 12,79 & 20,29 \\
\hline
\end{tabular}

${ }^{1}$ Médias trat.ou interações: ${ }^{* *}$ diferem entre si $(\mathrm{P}<0,01)$; ns $=$ não diferem $(\mathrm{P}<0,05)$.

${ }^{2}$ Determinações aos 6 meses correspondem a cálcio extraível. 
APÊNDICE 6 - Cálcio trocável em camadas do solo sob efeito dos tratamentos, em três épocas após a aplicação e resumo das análises estatísticas realizadas. Ensaio de métodos de correção, médias de 4 repetições.

\begin{tabular}{|c|c|c|c|c|c|c|c|}
\hline \multirow{3}{*}{$\begin{array}{l}\text { Prof. } \\
\text { Solo } \\
\text { (cm) }\end{array}$} & \multirow{3}{*}{$\begin{array}{c}\text { Tratamento } \\
\text { Condicionador } \\
\end{array}$} & \multicolumn{6}{|c|}{ Cálcio trocável/Época/Subsolagem } \\
\hline & & \multicolumn{2}{|c|}{9 meses } & \multicolumn{2}{|c|}{24 meses } & \multicolumn{2}{|c|}{40 meses } \\
\hline & & Sem & Com & Sem & Com & Sem & Com \\
\hline $0-15$ & $\mathrm{G}$ & 15,95 & 14,64 & 22,74 & 19,28 & 16,93 & 12,59 \\
\hline $0-15$ & E & 9,62 & 10,84 & 10,96 & 11,86 & 14,51 & 13,94 \\
\hline $0-15$ & $\mathrm{G}+\mathrm{E}$ & 17,05 & 15,97 & 17,95 & 20,20 & 14,84 & 15,42 \\
\hline $0-15$ & $\mathrm{P}$ & 9,93 & 10,08 & 11,07 & 11,38 & 10,93 & 11,75 \\
\hline $0-15$ & $\mathrm{G}+\mathrm{P}$ & 14,93 & 13,16 & 16,96 & 19,59 & 13,29 & 15,12 \\
\hline $0-15$ & $\mathrm{~T}$ & 8,49 & 10,16 & 12,58 & 10,84 & 13,79 & 13,05 \\
\hline $15-30$ & G & 12,43 & 10,04 & 16,98 & 14,43 & 14,16 & 11,74 \\
\hline $15-30$ & E & 8,97 & 10,57 & 11,55 & 11,30 & 14,82 & 13,98 \\
\hline $15-30$ & $\mathrm{G}+\mathrm{E}$ & 10,45 & 12,01 & 12,96 & 13,02 & 13,35 & 15,38 \\
\hline $15-30$ & $\mathrm{P}$ & 9,28 & 9,72 & 9,56 & 11,35 & 9,93 & 10,31 \\
\hline $15-30$ & $\mathrm{G}+\mathrm{P}$ & 10,53 & 10,87 & 13,29 & 14,88 & 12,75 & 15,04 \\
\hline $15-30$ & $\mathrm{~T}$ & 9,43 & 9,39 & 11,92 & 9,94 & 11,23 & 11,33 \\
\hline $30-45$ & G & 9,85 & 7,94 & 12,78 & 10,84 & 10,15 & 11,05 \\
\hline $30-45$ & E & 9,77 & 9,11 & 9,05 & 9,83 & 11,27 & 11,15 \\
\hline $30-45$ & $\mathrm{G}+\mathrm{E}$ & 9,67 & 9,66 & 9,04 & 9,69 & 12,05 & 11,52 \\
\hline $30-45$ & $\mathrm{P}$ & 8,29 & 9,01 & 7,44 & 9,50 & 10,46 & 8,69 \\
\hline $30-45$ & $\mathrm{G}+\mathrm{P}$ & 8,95 & 9,44 & 9,18 & 12,08 & 10,42 & 10,95 \\
\hline $30-45$ & $\mathrm{~T}$ & 8,29 & 7,85 & 7,33 & 8,03 & 8,62 & 10,76 \\
\hline $45-60$ & G & 7,23 & 7,04 & 7,75 & 7,52 & 6,34 & 8,16 \\
\hline $45-60$ & E & 7,64 & 8,61 & 7,65 & 8,19 & 6,72 & 7,05 \\
\hline $45-60$ & $\mathrm{G}+\mathrm{E}$ & 7,18 & 7,37 & 6,18 & 7,04 & 8,55 & 9,83 \\
\hline $45-60$ & $\mathrm{P}$ & 6,58 & 7,09 & 5,51 & 7,45 & 7,35 & 7,06 \\
\hline $45-60$ & $\mathrm{G}+\mathrm{P}$ & 7,21 & 8,16 & 7,20 & 10,07 & 7,70 & 8,14 \\
\hline $45-60$ & $\mathrm{~T}$ & 6,25 & 6,50 & 6,31 & 5,98 & 5,98 & 6,56 \\
\hline $60-90$ & G & 7,90 & 6,38 & 7,39 & 6,43 & 5,84 & 7,38 \\
\hline $60-90$ & E & 6,71 & 7,63 & 7,46 & 6,47 & 5,90 & 5,17 \\
\hline $60-90$ & $\mathrm{G}+\mathrm{E}$ & 6,81 & 6,53 & 5,29 & 5,92 & 8,12 & 6,93 \\
\hline $60-90$ & $\mathrm{P}$ & 6,70 & 6,65 & 5,75 & 7,23 & 7,12 & 4,26 \\
\hline $60-90$ & $\mathrm{G}+\mathrm{P}$ & 6,01 & 7,31 & 5,88 & 7,10 & 7,19 & 6,48 \\
\hline $60-90$ & $\mathrm{~T}$ & 6,87 & 5,41 & 6,82 & 4,77 & 5,95 & 6,99 \\
\hline \multirow{2}{*}{\multicolumn{2}{|c|}{ Valor $F:^{2}$ Subsolagem $(\mathrm{S})$}} & $\begin{array}{l}9,18 \\
\end{array}$ & 9,17 & 10,08 & 10,41 & 10,21 & 10,26 \\
\hline & & \multicolumn{2}{|c|}{$0,001 \mathrm{~ns}$} & \multicolumn{2}{|c|}{$0,34 \mathrm{~ns}$} & \multicolumn{2}{|c|}{$0,04 \mathrm{~ns}$} \\
\hline Valor $\mathrm{F}$ & ondicionador (C) & \multicolumn{2}{|c|}{$6,26^{*}$} & \multicolumn{2}{|c|}{$4,98 * *$} & \multicolumn{2}{|c|}{$8,61^{*}$} \\
\hline \multicolumn{2}{|c|}{ Val or F Profundidade $(\mathrm{P})$} & \multicolumn{2}{|c|}{$162 * *$} & \multicolumn{2}{|c|}{$232 * *$} & \multicolumn{2}{|c|}{$128 * *$} \\
\hline \multicolumn{2}{|c|}{ Valor $\mathrm{F}(\mathrm{S} \times \mathrm{C})$} & \multicolumn{2}{|c|}{$1,10 \mathrm{~ns}$} & \multicolumn{2}{|c|}{$1,70 \mathrm{~ns}$} & \multicolumn{2}{|c|}{$0,24 \mathrm{~ns}$} \\
\hline \multicolumn{2}{|c|}{ Valor $\mathrm{F}(\mathrm{S} \times \mathrm{P})$} & \multicolumn{2}{|c|}{$0,73 \mathrm{~ns}$} & & & & \\
\hline & $\mathrm{F}(\mathrm{C} \times \mathrm{P})$ & & & & & & \\
\hline Valo & $\mathrm{F}(\mathrm{S} \times \mathrm{C} \times \mathrm{P})$ & & & & & & \\
\hline HSD $-5^{\circ}$ & $(\mathrm{C}$ dentro de $\mathrm{P})$ & & & & & & \\
\hline C.V. C & dicionador (\%) & & & & & & \\
\hline C.V.P & ffundidade (\%) & & & & & & \\
\hline
\end{tabular}

${ }^{1} \mathrm{G}=$ Gesso; $\mathrm{E}=$ Esterco de curral; $\mathrm{P}=$ Palha de carnaúba; $\mathrm{T}=$ testemunha

${ }^{2}$ Médias de tratamentos ou interações: $\mathrm{ns}=$ não diferem entre si $(\mathrm{P}<0,05)$; ${ }^{*}$ diferem $(\mathrm{P}<0,05)$;

** diferem $(\mathrm{P}<0,01)$. 
APÊNDICE 7 - Composição química e classificação da água de irrigação do Campo Experimental da EMPARN em Ipanguassu-RN.

\begin{tabular}{cc}
\hline DETERMINAÇÃO & VALOR \\
\hline Condutividade Elétrica $\left(\mathrm{dS} \cdot \mathrm{m}^{-1}\right)$ & 0,44 \\
$\mathrm{pH}$ & 7,8 \\
Carbonato $-\mathrm{CO}_{3}^{-2}\left(\mathrm{mmol}_{\mathrm{c}} \cdot \mathrm{L}^{-1}\right)$ & 2,02 \\
Bicarbonato $-\mathrm{HCO}_{3}^{-}\left(\mathrm{mmol}_{\mathrm{c}} \cdot \mathrm{L}^{-1}\right)$ & 1,30 \\
Cloreto $-\mathrm{Cl}^{-}\left(\mathrm{mmol}_{\mathrm{c}} \cdot \mathrm{L}^{-1}\right)$ & 1,23 \\
Cálcio $-\mathrm{Ca}^{+2}\left(\mathrm{mmol}_{\mathrm{c}} \cdot \mathrm{L}^{-1}\right)$ & 1,07 \\
Magnésio $-\mathrm{Mg}^{+2}\left(\mathrm{mmol}_{\mathrm{c}} \cdot \mathrm{L}^{-1}\right)$ & 1,64 \\
Sódio $-\mathrm{Na}^{+}\left(\mathrm{mmol}_{\mathrm{c}} \cdot \mathrm{L}^{-1}\right)$ & 0,09 \\
Potássio $-\mathrm{K}^{+}\left(\mathrm{mmol}_{\mathrm{c}} \cdot \mathrm{L}^{-1}\right)$ & 282 \\
Sólidos Totais Dissolvidos $\left(\mathrm{mg}^{-1} \mathrm{~L}^{-1}\right)$ & 1,48 \\
Relação de Adsorção de Sódio $(\mathrm{RAS})$ & $\mathrm{C}_{1} \mathrm{~S}_{2} \mathrm{~T}_{1}$
\end{tabular}

${ }^{(1)}$ Baseada em Pizarro (1985) e Ayers \& Westcot (1991).

$\mathrm{C}_{1}$ - Água de baixo risco de salinidade.

$\mathrm{S}_{2}$ - Índice médio quanto a riscos de problemas de infiltração no solo (sodicidade). $\mathrm{T}_{1}$ - Água sem de problemas de toxicidade de sódio e/ou cloreto para as plantas. 
APÊNDICE 8 - Pluviosidade mensal registrada no posto pluviométrico de Pataxós, município de Ipanguassu-RN, no período de 1989 a 1993.

\begin{tabular}{crrrrr}
\hline & \multicolumn{4}{c}{ ANOS - Pluviosidade (mm) } & \\
MESES & 1989 & 1990 & 1991 & 1992 & 1993 \\
\hline Janeiro & 20,0 & 0 & 0 & 215,4 & 11,4 \\
Fevereiro & 28,8 & 31,8 & 51,2 & 108,4 & 3,4 \\
Março & 101,0 & 69,4 & 132,8 & 86,4 & 18,6 \\
Abril & 263,4 & 101,4 & 229,2 & 95,4 & 89,0 \\
Maio & 81,0 & 44,6 & 45,8 & 14,4 & 19,4 \\
Junho & 65,2 & 30,6 & 134,6 & 0 & 0 \\
Julho & 154,0 & 41,0 & 8,5 & 0 & 23,2 \\
Agosto & 0 & 8,4 & 0 & 0 & 0 \\
Setembro & 6,2 & 5,8 & 0 & 0 & 0 \\
Outubro & 0 & 0 & 0 & 0 & 0 \\
Novembro & 20,4 & 0 & 0 & 0 & 0 \\
Dezembro & 117,8 & 0 & 0 & 0 & 0 \\
\hline TOTAL & 857,8 & 289,6 & 551,9 & 520,0 & 165,0 \\
\hline
\end{tabular}

